Posiciones, causas y razones en los $R v f: 2$. - De nuevo sobre el 153 y sus huellas...

\title{
POSICIONES, CAUSAS Y RAZONES EN LOS RVF: 2. - DE NUEVO SOBRE EL 153 Y SUS HUELLAS. MUERTE DE LAURA, PROVIDENTIA Y DIVINA PROPORTIONE
}

Antonio ARMISÉN

Universidad de Zaragoza

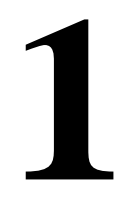

Las propuestas introductorias del 2004. Numerus, rationes y forma narrativa del Canzoniere. Sentido y función de las supuestas macrosecuencias particulares. Las imágenes retrospectivas, los De musica libri VI y otros detalles de la huella de Confessiones. Los límites de la condición modular.

En marzo de 2004, señalé la influencia activa del sistema numérico de Agustín en los Rerum vulgarium fragmenta de Francesco Petrarca con un trabajo en el que, junto a otras observaciones útiles, sugerentes o siquiera centrales en las propuestas planteadas en aquel momento, apuntaba dos casos particulares apenas esbozados. Merecían atención por razones que no era el momento de comentar con más espacio. Recuperaba e intentaba describir entonces un código numérico operativo, sencillo y más perceptible, antes verificable en el ulterior canzoniere de Boscán impreso en 1543, de acuerdo con propuestas publicadas en 1982. Las de marzo de 2004, presentadas en el Palazzo Maldura e impresas ese mismo año en $C u F I$, eran lecturas sobre la composición narrativa unitaria de las rime sparse que han sido ampliadas y completadas en alguna medida o inclu so confirmadas e interpretadas con más detalle en publicaciones posteriores (2005, 2008, 2011, 2012 y 2013).

Si en 2004 y 2005 anunciaba la aparición de un libro sobre problemas de la composición numérica en los canzonieri petrarquistas y las sonnet sequences, el desarrollo final y crecientes requerimientos de los trabajos previos impusieron después la conveniencia de optar por un programa de publicaciones distinto y fragmentado, que retrasaba temporalmente ese libro, entonces en avanzado estado de redacción. Artículos impresos desde esas fechas y otros pendientes de publicación dan cuenta de buena parte de las propuestas de aquel proyecto, de su ejecución y transformaciones hasta finales del 2012. El silencio casi general, imperante tras los homenajes y publicaciones del 2004, difícilmente puede interpretarse hoy como desinterés en los problemas de la forma del Canzoniere o en su lectura. Sirvan estas líneas iniciales de enero del 2013 en cuanto revisión o recordatorio del tema y justificación del retraso de un libro, anunciado años antes como próximo, para el que todavía no hay fecha. 
Según la opinión que adelanté como propuesta inicial en Padova en el año del séptimo centenario del poeta de Arezzo, el sistema numérico de Agustín -explícito en los comentarios del In Iohannis evangelium tractatus (122, 1-9) y las Enarrationes in Psalmos (Ps. XLIX, 9; Ps. CL, 1-8)- tenía aplicación activa verificable en el codice d'autore de Petrarca. Si entonces los dos casos que describía como propuestas particulares fueron siquiera delimitados en cuanto posibles secciones significativas o presumibles secuencias (2004a: 93-94), será oportuno completar su repaso con atención a las posiciones marcadas, causas y razones reconocibles en la composición del codice Vat. lat. 3195.

Como he venido señalando en referencia a momentos y formas textuales semejantes de los $R v f$, los elementos que actualizan demarcativamente los límites de esos dos componentes macrosecuenciales no parecen reiteraciones gratuitas o casuales. Su coincidencia en la cifra e interrelación presumible o supuesta por el lector, merecedoras de atención y tal vez no resueltas, plantean problemas diversos. Nos ayudarán a entender mejor el problema narrativo y plural de la compleja e imbricada textualidad unitaria del Canzoniere.

Leemos una estructura funcional con frecuencia tejida por la recurrencia de fórmulas perceptibles, de componentes discursivos, de formas expresivas (...conessioni de trasfomazione/ equivalenza: Santagata 1975 y [1979] 1989; Brugnolo 2004: 126) y de sostenidos motivos temáticos; o construida con la connotación simbólica (paradigmática/sintagmática) que los marca in ordine, temporal y posicionalmente, activamente integrados en el sucesivo continuum, en la forma espacial (arquitectónica, textual, reticular) de narración modular y plurisecuencial del libro. Armisén 1982: 389 ss. y n. 156; recientemente 2012: 80 ss.

Continúo así la verificación de la huella numérica de Agustín, coincidente con la influencia autobiográfica de Confessiones, consecuente con su teoría del numerus, sostenida por la numerología cristianizada y evangélica, acorde con la aspiración a la armonía y los números eternos planteada en los libros I y VI de los De musica libri VI, aludida en De libero arbitrio, Lib. II, XVI, 42. Armisén 2012 y 2013. Creo que la vaticinatio post eventum sobre la muerte de Laura, que cifra el sentido de Morte en los $R v f$ y articula su personal relación dialógica con Augustinus, completa el artificio del continuum de poesia con los consejos del magister y las respuestas de Francesco. La ficción del Secretum enriquece los Rerum vulgarium fragmenta, provee claves de lectura y da forma literaria al caso. Conocer la puntual y sostenida relación del diálogo ficticio con los $R v f$ confirmará, desde el sonetto CXVIII y el año 17 de su pasión amorosa, la lectura cifrada en el libro de rime cerrado definitivamente en 1374 con la muerte de Petrarca.

La composición que estudio resulta en destacadas ocasiones de la intención narrativa unitaria, también de la consciente búsqueda de coherencia semántica que la ordenación marca biográfica y temporalmente; pero crece o se apoya formalmente en la cohesión lingüística que otras múltiples repeticiones (genéricas, métricas, sintácticas, temáticas y léxicas...) permiten al lector, establecen e incluso potencian. Cappello 1998: 188 ss. Si el soneto, reducido salón de espejos delimitado por sus números conocidos, breve asimetría ajustada a ratio, es en sí una reiterada máquina de significar con 
posibles orígenes matemáticos, no es tampoco la única forma numérica y rítmica por considerar en el textus.

El Canzoniere, con la sucesión de versos y formas conocidas, se construye unitario, sobre todo, en la ordenación espacial, posicional de los 366 elementos cerrados por la coda mariana. Las agrupaciones y secuencias temáticas, integradas en ese continuum, configuran una estructura fundada en el numerus y sus límites, pautada repetidamente por el modulus de Agustín (en el caso de Petrarca con posibles antecedentes en Vitruvio), y en ocasiones significada por sus posiciones, causas y rationes. Armisén 2008a: 56, n. 3; también 2013: 199 ss.).

La condición narrativa imbricada y modular, reticular del laberinto entretejido como peregrinatio tiene antecedentes simbólicos que no cabe ignorar en el Viejo testamento (Salmos particularmente), en la materia evangélica (figurae, vita Christi e incluso «sistema di preghiere»...) o en el redentorismo neotestamentario y las Confessiones de Agustín; pero también en la escritura de Virgilio, Horacio, Ovidio o Catulo y, de forma documentada en más de una ocasión, en el textus de la Eneida (Armisén 2012: 83, 89 y 99; et infra texto y nn. 26, 31). No nos centraremos ahora en una lectura de sus referentes próximos reconocidos. Estudiar los límites de su relación discursiva y exegética con el precedente bíblico en cuanto textus continuum de elementos sucesivos mediante el desarrollo de la hermenéutica oportuna nos llevaría demasiado lejos. Frye (1982) 1988: 236 ss. et al.

El simbolismo numérico, componente activo del enigma textual, se presenta apoyado por reiteraciones propias del lenguaje poético que multiplican las posibilidades de simetría y paralelismo. En ocasiones, en relación con temas y problemas destacados sostiene la medida recurrencia discursiva de micro y macrotexto en los $R v f$. La forma numérica cristianizada por Agustín se convierte así en elemento constitutivo, unificador e intencional de la narración secuencial que el lector propio puede (o tal vez debería...) reconocer.

La lectura del lector creyente, pietoso, devoto y compasivo o siquiera interesado conocedor de los problemas de la espiritualidad encuentra en el proyecto formal de Petrarca, desde el sonetto inicial o su propositio, despues con la guía del Secretum y la anterior petición de «le fila benedette» del sonetto XL, el tessere redentorista sostenido por la escritura poética y la numerología cristiana de Agustín. Armisén 2012: 80 ss. y 86.

En el códice concebido por Petrarca la ordenación grafico-visiva de los autorizados 72 folios numerados (Armisén 2011: 15-16; y Armisén 2012: 87; contrástese ahora con lo que sobre las 72 naciones, sus 72 lenguas y los antípodas dice Agustín De civit. Dei.: XVI, 9 y XVI, 10, 3) el poeta realiza o completa una forma modular y reticular significativa, con frecuencia apoyada en lo posicional, unificada, armonizada y potenciada con los agustinianos numeri aeterni. Como ocurre con otras formas de composición numérica, la macroforma unitaria de los $R v f$ se presenta en aparente relación isomórfica (ocasional y repetidamente) con sus elementos modulares menores, básicos o fundamentales.

La coincidente ratio sesquitertia en texto literario y codice d'autore, localizada en 2008: 58 ss., permite considerar siquiera la incidencia en la composición proporcional de la forma sonetto (8/6 ó 
4/3; 88/66 en sus regulares 154 sílabas [Pötters 1998: 21-81]) y la de la escritura poética posicional -simetría/asimetría- que le es natural. El problema de la belleza o el sentido y su relación con el numerus o las rationes ha de entenderse presente en unidades menores y mayores, desde el ritmo discursivo sensorial y la métrica a la macrocomposición modular unitaria (y redentorista) que permite alcanzar y reconocer después la naturaleza textual de dicho ritmo. Vid. Luque Moreno - López Eisman, «Introducción» al De musica, 2008: 46-49. Pero estas conclusiones circunstanciales no son ahora sino nuevas observaciones previas que conviene recordar todavía. Su relación con motivos, temas destacados y problemas centrales del texto semeja verificable. Una articulación operativa que parece consciente, concebida y elaborada desde el proyecto, con aplicación intencional o más directa.

Manteniendo aquí el orden de presentación del trabajo de 2004, antes mencionado, me centraré inicialmente en la macrosecuencia CXXIX-CCLXXXI, delimitada y cifrada por el 153/154 de Agustín, marcada temáticamente y sostenida por la recuperación mnemónica (phantasia), soñada, imaginada (phantasma) y visual de Laura in vita e in morte. De musica, VI, 11, 32.

Pero el asunto tiene presencia reconocible a valorar en textos anteriores a los que ahora consideramos. No se trata, por tanto, de un motivo iniciado por la canzone CXXIX, vv. 40-43. Primero la ausencia y el premonitorio temor, temas conocidos, y después la muerte, desde 1348, puede que sean causa y razón que, con el problema de la recuperación visual de la amada, tras las repetidas figure compensative de la serie de canzoni CXXV-CXXVII (ed. Bettarini 2005: 625 et al.), explican mejor en términos de composición narrativa el miraggio o allucinazione visiva de la última canzone del ciclo de cinco, la CXXIX in vita. La forma que estudiamos se presenta introducida por textos y temas previos.

Si bien ya la canzone CXXIX, vv. 40-52, superando la separación de la amada, señaló una visión («fantasia» / «fantasma» sic. Agustín) sagrada y repetida, obsesiva de Laura viva en «la quarta stanza...culmine del processo autoillusorio» (Gantert 2000: 64) «ne l'acqua chiara e sopra l'erba verde», v. 41, evocada aún, recuperada 153 pezzi después in morte con el sonetto CCLXXXI «Quante fiate al mio dolce ricetto», ... parece oportuno conocer ahora que el módulo de 17 se confirma reticular, 51 pezzi después, como pauta significativa que todavía reaparece hasta el final del libro en textos importantes por diversas razones como la sestina doppia CCCXXXII (72 vv.+3) y el sonetto CCCXLIX. Porque no se trata tampoco de un caso aislado. Armisén 2011; y 2013.

Destacaré también la lectura por Vellutello de «Quante fiate al mio dolce ricetto» (1525: 143, recto; 1538: 115, recto). La edición del 1538 amplíficaba algo la anotación de la visión in morte del sonetto CCLXXXI. En sus espositiones interpreta el texto en relación con la anterior, repetida y constante recuperación visual de Laura por referencia explícita al famoso CLIX in vita «In qual parte del ciel, in quale ydea», texto que trata otra vez de la creación de Laura. Y entonces lo hacía en relación con el mundo de las ideas platónicas. No todos los contrastes que la sucesión posicional y temporal permite se fundan en las formas numéricas, pero alguno de ellos sí potencia su significado con las cifras de composición que estudio. 
No dudo que la espositione del lucchese sobre este sonetto CLIX (Ibid. 1525: 58 recto y verso; 1538: 48 recto y verso), comentario que incluye la mención de Leonardo da Vinci y su tratamiento pictórico de la imagen femenina de la Virgen María, tu vo algo que ver con la valoración del mismo en el siglo XVI y con la atención sostenida de los lectores a la mnemónica visión de Laura. Un texto con reconocimiento reiterado en la tradición poética castellana ${ }^{1}$.

Y tal vez sea oportuno advertir que, 153 pezzi tras el sonetto IV de la creación de Laura (y el V que, con el inicio del proceso de búsqueda, confirmará inmediato el interés del nombre y de la identidad inscrita) el sonetto CLVII «Quel sempre acerbo et honorato giorno», integrado en la microsecuencia de il pianto di madonna y su condición pietosa (CLV-CLVIII/CLIX; Bettarini ed. 2005: 756 et al.; McLaughlin 2007: 367-382), ofrece como recuerdo una interesante descripción física y retrospectiva de Laura rememorada, con mención del «dolce amaro lamentar», v. 6, y con señalados antecedentes en Eneida, V, vv. 49-50 y en Vita nuova, XXII (ibid. 2007: 375).

Tengamos presente lo que se ha dicho sobre el sonetto CLIII «Ite, caldi sospiri, al freddo core» como «inizio di un epitaffio in vita» (ibid. 367 y 375) y sobre sus posibles implicaciones numéricas (Armisén 2013: 221). Recordemos también que la macrosecuencia V-CCCLXVI de 362 unidades, como advertí en el 2008, tiene su centesimal y exacta ratio sesquitertia en la conocida data sacra del sonetto CCXI, vv. 12-14.

Aunque las explicaciones de Vellutello subrayan algunos temas sostenidos o repetidos, la reordenación propuesta desde 1525, tantas veces reimpresa, con su rechazo de la forma autorizada negaba la composición de los $R v f$ asumida (de forma dispar) por las ediciones aldinas de 1501 o 1514. Con la reordenación, cuestionaba en su prólogo ese ordo e impedía o retrasaba el reconocimiento de la forma unitaria original y de la recurrente forma narrativa secuencial que estudio. Pese a ello, las varias ediciones de esos comentarios confirman que numerosos lectores - no todos ellos ajenos a la composición intencional del poeta, hemos de pensar- reconocían con el propio Vellutello, antes y después de 1525, estas reiteraciones de temas, motivos y formas expresivas como parte constitutiva de la poesía narrativa de Petrarca.

La trabajada macrocomposición pensada por Petrarca, destinada a provocar una lectura espiritual, pietosa (sonetto I, v. 8), se afirma después con la pietà amorosa o la compasión posterior

\footnotetext{
${ }^{1}$ Mereció el recuerdo y la imitación de Boscán: «En cual parte del cielo, en cual planeta», soneto LXXX [52] y último de los cuatro sonetos centrales que loan el nacimiento de la amada en su canzoniere castellano (Barcelona, 1543). También lo imita Gutierre de Cetina con intención contrastiva en «En cual región, en cual parte del suelo». Siglos más tarde, tras la edición del poeta barcelonés por Martín de Riquer, A. Comas y J. Molas (Barcelona, 1957), muy probablemente atento al componente platónico del texto de Petrarca y a las mencionadas imitaciones castellanas, con intención paródica, lo evoca Jaime Gil de Biedma en «París, postal del cielo» (vv. 19-20), provocador, amoroso e irónico poema de ausencia moderno y urbano. (Moralidades, 1966): «¿En qué sitio perdido / de tu país, en qué rincón de Norteamérica / ...». Armisén 1982: 391-394 et al.; y 2007: 33-34. La ubicación por Boscán del soneto como 52, central del Libro II de Boscán de 102 componentes, podría, quizá, incluso suponer alguna atención de Jaime Gil a su posición, reconocible en la ed. de Riquer. Más debía interesarle como reto la conocida opinión de Menéndez Pelayo: «El soneto mejor imitado es sin disputa...» (ed. Obras comp.., vol. X, 1945: 247), pese a que el cántabro, al parecer, permaneció por completo ajeno a la forma narrativa y la composición del primer canzoniere castellano impreso. Don Marcelino, bibliófilo que poseyó y tuvo que conocer la princeps del «Boscán y Garcilaso» (Barcelona, Amorós, 1543), en su tardío libro sobre Boscán (1908) trabajaba con la edición moderna (W.I. Knapp, Madrid, 1875), ajena al ordo original (y en mi modesta opinión inadecuada), por la que cita. No parece que prestase atención ninguna a la forma canzoniere en la edición de 1543. Véase Armisén 2011c (2014): n. 27.
} 
-anhelada, supuesta y tardía- de la mujer amada. Apoyará su lectura contrastiva in morte con el antecedente de las reiteradas visiones in vita de Laura y en particular la descrita con énfasis en la cuarta stanza de la canzone CXXIX «Di pensier in pensier, di monte in monte», en un espacio mental y natural, antecedente visual evocado después, reconocido por los lectores y valorado por la crítica.

La visión obsesiva, reiterada «I' l'ò più volte (or chi fia che mi 'l creda?) / ne l'acqua chiara et sopra l'erba verde / veduto viva...», CXXIX, vv. 40 ss., señalada y marcada pronto, será recordada después con textos señalados que confirman -en otro momento hemos visto alguno- la constancia inalterable y largo aliento de su pasión amorosa (sonetti CXVIII, CXLV, CCXI, CCXII et al.; Armisén 2008a: 62, n. 10; 2010: 43 ss. y nn. 35 y 36; 2012: n. 1). El motivo reaparece, evocado en términos reconocibles de la muy semejante visión in morte, formando una presumible secuencia de 153 fragmenta con la recuperación visionaria finalmente completada, órfica y cristiana del sonetto CCLXXXI, vv, 12-14 (forma Correggio, vid. Santagata [1996] ed. 2004: 1127 y 1132; también Pacca [1998] 2004: 156-159; y Benini 2000: 97 ss.). En mi comunicación oral e impresa (2004a: 89 y 93-94) adelanté que esa distancia simbólica de 153 pezzi podía, quizá, considerarse indicio o huella precisa verificable de la acción de Providencia en el caso.

Es la nueva Laura recuperada in morte, con huellas de creciente compasión amorosa: «or l'ò veduto su per l'erba fresca / calcare i fior' com'una donna viva, / mostrando in vista che di me le 'ncresca», CCLXXXI, vv. 12-14. Los textos inmediatos dan mayor relevancia a una recuperación marcada por la sagrada, íntima visión recurrente. Vid. M.C. Bertolani 2005: 29 ss., 134 ss. et al. En sus comentarios, Tonelli (1999: 80-82) lo considera forma reiterada; y Bettarini (ed. 2005: 1265-1267) describe el diseño sintáctico estrófico («Quante... // Quante... // Or... // Or...») como forma destinada a expresar la condición recurrente, «Il processo psicologico ripetitivo della visione». Destaca también el conocido antecedente de la canzone CXXIX, vv. 40-43; y anota verso a verso expresiones y fórmulas antecedentes y coincidentes. Es texto descriptivo obsesivo, memorable, que repitiendo la visión modelo, reinicia después in ordine un ciclo con precedentes en los Rvf. Baranski 2007: 617 ss.

Esa macrosecuencia particular, marcada con el tema de las visiones de Laura por el módulo de 17 [153 es 17x9] reaparece, tal vez, si reconocemos la importancia temática, narrativa o compositiva señalada, perceptible en varios pezzi destacados, quizá conformados a la misma pauta modular que nos devuelve, antes y después, a posiciones funcionales en los límites de la macrosecuencia de il riscatto LXI/LXII-CCCLXVI de 306 unidades [153+153 ó mejor 17x17+17]: LXI/LXII [...] CXXIX, CXLV [...] CXCVI, CCXIII [...] CCLXIV [...] CCLXXXI, CCXCVIII, CCCXV, CCCXXXII, CCCXLIX y CCCLXVI. La posibilidad de leer la secuencia particular de la recuperación visual de Laura in vita e in morte de 153 pezzi (CXXIX-CCLXXXI) integrada en la macrosecuencia de 306 unidades parece cierta, pese a sus perceptibles y leves desajustes ${ }^{2}$.

\footnotetext{
${ }^{2}$ La doble macrosecuencia LXI-CCCLXVI está formada por 306 pezzi. Armisén 2008a: 52-54, 58 ss. et al.; y 2011 : 11 et al. ; 2013: texto... y n. 14. Si iniciamos la macrosecuencia con el sonetto LXI, la canzone CXXIX sería el texto número 69 (el 68 [17x4] lo ocupa la CXXVIII «Italia mia...»). Tomando como referencia inicial la prima preghiera cristiana del sonetto LXII, el 68 es la canzone CXXIX, inicial de la macrosecuencia particular de las visiones in vita e in morte de 153 componentes (CXXIX, vv. 40 ss.-CCLXXXI, vv. 12-14).
} 
Después, la adecuación funcional unitaria del libro se acentúa como forma rítmica modular cifrada por el 17, más regular y perceptible en sus últimos elementos nodales. Cuando el final se acerca, se funden y confluyen motivos recurrentes, formas crecientes en progresión con las últimas peticiones o con otros componentes de cierre. No debe extrañarnos su plural imbricación secuencial ni la simplificación final de su pauta narrativa.

En cuanto formas implícitas, propias de una lectura narrativa secuencial, fácilmente las reconoceríamos activas en otros muchos textos en prosa, no ordenados necesariamente por sucesión numérica. En este caso la cifra significativa las acompaña y las señala con el silencio de lo implícito, ofrece una vía de comprensión unitaria marcada en las secuencias más importantes por rationes, pero perceptible y verificable o confirmada por el numerus cristianizado por Agustín. Si los pezzi del «codice d'autore» carecen de números de cabecera que situen al lector, su oportunidad y presencia necesaria la reconocieron pronto los editores. La diversidad de ordenaciones posible no es gratuita, ni era ajena al propio poeta.

El segundo caso particular de secuencia apuntado en el trabajo de 2004, anterior siquiera por su inicio en la solapada o superpuesta disposición in ordine del continuum, es el señalado entre el sonetto CXVIII «Rimansi a dietro il sestodecimo anno» (fol. 24 verso) y el CCLXXI que comienza «L'ardente nodo ov'io fui d'ora in hora / contando, anni ventuno interi preso» (fol. 56 recto) Armisén 2013: 204 ss. Declara abiertamente su referencia temporal desde los primeros versos. Con toda evidencia, la cronología es elemento constitutivo explícito, demarcativo; pero es también motivo temático simbólico nodal o central de la secuencia que construye desde el CXVIII como sonetto di preghiera, (vv. $5 \mathrm{ss}$ ), tal vez descriptible ahora con propiedad como «dramma di numeri e di proporzioni». Según ocurre repetidamente con otros sonetti de interés posicional, «Rimansi a dietro il sestodecimo anno», en los inicios del año 17, usa formas y fórmulas expresivas conocidas, reconocibles para lectores atentos (Bettarini ed. 2005: 543).

Añadiré otras, quizá de mayor relevancia, ignoradas o descuidadas por comentaristas y anotadores, como la condición agustiniana de esa preghiera cifrada que, además de su perceptible relación con el Secretum, tiene el antecedente directo de Confessiones (Lib. IV, caput 5, 10) y lo que Agustín dice ahí sobre las peticiones al Señor (in precibus...) y el llanto dolce et amarum. ${ }^{3}$

La condena de «l'empia Fortuna» incluye así elementos de una profecía que, señalada y valorada por Rico (1974: 284 ss. y n. 123), en mi opinión, apunta también como prótasis, con el precedente de su conocido modelo, al triunfo final de Providencia, paradoja verificable, resuelta después con los términos numéricos redentoristas del mismo Agustín.

\footnotetext{
${ }^{3}$ Petrarca hace uso de una forma conocida que en Confessiones (Lib. IV, caput.5, 10) introducía una paradoja enigmática relacionada en ambos casos con el llanto (..cur fletus dulcis sit miseris?), antes ya vinculada al conflicto Amor/Muerte, con antecedentes en Platón, en Safo y la tradición órfica que no sabemos si Petrarca conocía. Véase el tema de Amore amaro en Rvf CCCXLIV, vv. 1-3 (Santagata ed. 2004: 1332-1333) y en Triunfus Cupidinis, I, vv. 76 ss. (V. Pacca ed. 1996: 7071). Sobre el dolce amarum y otras valoraciones en el renacimiento vid. E. Wind [1968] 1972: 72 ss.; Armisén 1982: 306, 326-327 y n. 319, 331 nn. 328; 398 y 401 n. 201. También, en relación con Boscán y el mito de Leandro, vid. R. Behar, 2013: 294-295.
} 
L'amar m'è dolce, et util il mio danno, e 'l viver grave; et prego ch'egli avanzi l'empia Fortuna, et temo no chiuda anzi Morte i begli occhi che parlar mi fanno (vv. 5-8).

No dudo que Petrarca conoce bien ese motivo de Confessiones y sus circunstancias: la perdida irrecuperable del ser querido (vid. Stroppa 2014: 96), las limitaciones (in morte) de su condición de phantasma (Confess. IV, 4, 9; De musica, VI, 11, 32) y la sostenida crisis de su esperanza son temas perceptibles en los $R v f$, como tampoco ignora («et d'antichi desir'lagrime nove...», vv. 12-14) sus reiterados temores personales formalizados en la secuencia de las enfermedades y muerte de Laura XXXI-CCCXXXVI (Armisén 2008a: 49-51), la frecuente meditatio mortis -tema del Secretum- o su propia experiencia y las implicaciones de sus versos en la gran macrosecuencia que se inicia CXVIIICCCLXVI, ni la función operativa del 153/154 (CCLXX/CCLXXI) en esa importante sección final de 249 fragmenta del Canzoniere. Vid. infra.

La inmediata canzone CXIX «Una donna più bella assai che '1 sole» es la conocida como canzone della Gloria, tradicionalmente relacionada con la incoronazione poetica y texto alegórico que presenta el conflicto, comentado en el Secretum (II, 80 ss.; y III, 130 ss.), entre su conocida pretensión de Gloria (An lingue gloriam sectatus dicor qui... Secretum, II, 78 [Dante, Purg. XI, 97-98]) y la deseada Virtud. [Pötters 1987: 64-65 (?) y 66-72; Santagata 2004: 550 ss.] Si, de acuerdo con Picone (2007b: 289 ss), la canzone CXIX supone un cambio hacia la materia poetologica y la aspiración a la Gloria literaria, el contraste («stridente contrasto con l'atto di accusa pronunciato da Augustinus nel Secretum...»; ibid.: 290) con las admoniciones y amenazadoras advertencias que acompañan el velado vaticinio (Secretum, III, 136-138) se hace más evidente. Rico 1974: 284-285; Armisén 2013: 206 ss, y 232 n. 22.

Las palabras finales de la donna en el v. 102 («dicendo: -Non temer ch'i’ m'allontani-»), cuando le hace entrega «di verde lauro una ghirlanda», ...y el commiato de la canzone CXIX, vv. 106-112, marcan ahí un nudo narrativo de la storia por desarrollar, quizá relacionado con la valoración positiva de su amor por Laura y sus efectos en la escritura poética, pero también apuntan a un desenlace -tal vez respuesta a temas discutidos en el Secretum - aún por resolver. Podemos pensar que la condición de múltiplos de 17 tanto en el caso del v. 102 de la afirmación de la donna como en el 119 que establece la posición de la canzone son en esta ocasión solo casuales coincidencias que, al menos, no deben pasar inadvertidas ${ }^{4}$. La macrosecuencia CXVIII-CCLXX / CCLXXI-CCCLXVI en cuyo inicio se integra «Una donna più bella...» ofrece otros motivos de mayor interés. Debemos ir a ellos.

\footnotetext{
${ }^{4}$ En las Enarrationes in Psalmos (Ps. CL, 1), comentando el simbolismo numérico de los 150 salmos y repasando su anterior interpretación del 153 de la pesca milagrosa, Agustín señala que el Psalmus CXIX era el primero de los salmos de grado (Ps. 119-Ps. 133) que reciben su nombre y número de los peldaños por los que se accedia al Templo. No creo que esos datos sostengan una lectura del texto de Petrarca, pero sí permiten advertir el interés de la numerología anterior aplicada en espacios y textos sagrados, parcialmente conocida siquiera por algunos lectores atentos de Agustín entre los que podemos situar al propio poeta.
} 
Integrar estos textos y esa secuencia modular en el sistema de aniversarios o en el de preghiere permite verificar que la posibilidad que exploramos no se cumple exacta y regular en todas las posiciones posibles de las secciones y macrosecuencias temáticas del continuum. Según he advertido hace años, la pauta modular reaparece en relación con peticiones, motivos, posiciones y temas varios, pero no se presenta de forma obligada, sistemática o regular. Su verificable repetición y la condición esencial (numérica y agustiniana) que le es propia la convierten en forma implícita operativa, especular y más accesible a sus lectores propios. Otras veces - y no pocas, dudas aparte- ha de resultar escasamente fehaciente para lectores críticos de nuestro siglo, parece de intencionalidad funcional cuestionable o es directamente rechazable.

Como digo, no se trata de una forma de cumplimiento obligado o sostenida siempre, regularmente. Valorar como más relevantes los pezzi iniciales y finales (o los que son chiave de conocidas rationes) en el reconocimiento y delimitación del significado secuencial unitario de la sección (Agustín, De musica. I, 11, 18) parece oportuno si, de acuerdo también con la opinión de A. Fowler (1993: 845) y R. Jakobson, la forma numérica es (puede ser...) considerada recurso constitutivo de la secuencia. El reconocimiento e interpretación en los casos particulares depende del lector, de sus motivaciones, información y capacidades o competencia. No puede extrañarnos, si contrastamos medidas y datos con los que la composición o la presencia modular permiten verificar de forma menos precisa, parcial y selectiva u ocasional en las formas arquitectónicas o pictóricas, por ejemplo.

Como veremos, conocer esa exacta e irregular pauta numérica agustiniana y su documentado sistema numérico mejora repetidamente la lectura del texto; y completa o enriquece el mismo con datos formales y simbólicos significativos, útiles en ocasiones e incluso decisivos en la lectura narrativa unitaria y espiritual del corpus. Quizá, tras las repetidas alusiones de la crítica al antecedente arquitectónico conocido, tampoco resulta necesario contrastar esa funcionalidad proporcional, rítmica y armónica con la que ofrece su presencia modular en otras formas artísticas. Su reconocimiento y validación no quedan, desde luego, limitados por antecedentes vitruvianos que el estudioso, conocedor siquiera parcial de la biblioteca y lecturas de Petrarca, no deberia ignorar.

Volvamos a la lectura particular del Canzoniere que nos interesa ahora. Centrémonos en la macrosecuencia CXVIII-CCCLXVI que revisamos. Estamos también, más adelante, en el año veintiuno con el sonetto CCLXXI que, tras la data sacra del CCXI, establece un nuevo punto de partida, inmediatamente confirmado desde el sonetto CCLXXII «La vita fugge, et non s'arresta una hora» (Santagata ed. 2004: 1110; y 2005: 20 ss.; contrástese con Bettarini ed. 2005: 1238). Pronto encontramos las primeras consecuencias de la muerte de Laura. El interés del problema se potencia y renueva con la recientísima publicación de un estudio monográfico sobre Morte en el Canzoniere y las Familiari que conozco tarde, con este artículo ya en prensa (S. Stroppa: 2014). El lector interesado habrá de contrastar el presente trabajo con lo que la estudiosa italiana escribe sobre «La richerca di una consolazione ( $R v f 270) »$ en 2014: 246 ss. y 254-262; o, más detenidamente y referido al tema en 
todo el libro, sobre «Il pensiero della morte nei Rerum vulgarium fragmenta», ibid.: 195-290. Lamento no poder comentarlo ahora con el espacio que merecen sus propuestas.

Muchos textos después del primer conocimiento de esa grave pérdida, Petrarca fechará la que desde 2004 considero data tragica, tardia y finalmente explícita en posición destacada (desplazada) y significativa, explicable tal vez por razones de composición cifrada, mediante el sonetto CCCXXXVI (fol. 66, verso; Armisén 2008a: 49-51). Tanto la voluntad final de conservar esa particular y retrasada posición in ordine, en el límite de los textos reordenados por las postille, como la misma fórmula discursiva del CCXI, ahora repetida, su posición relativa como segundo soneto en los respectivos folios, el número y posición final de sus versos (vv. 12-14) o la coincidente fecha de ambas precisas dataciones (data sacra y data tragica) confirman al lector atento, motivado, el interés compositivo y su localización intencional en el codice. Santagata 2004: 1314. Si atendemos a esos lectores y a sus imitaciones, no es la única causa o razón a valorar (Armisén 2012: 94-95).

Con la distancia que pauta el ordo y ritmo modular, la composición que distingue la forma posicional, espacial y numérica del Canzoniere de otras articulaciones narrativas se hace, una vez más, evidente por varias vías. Saber que esa composición, en muchos detalles, asume y potencia el sentido espiritual o religioso e incluso teológico de la recurrente lectura literal ayudará a percibir su trabajada operatividad.

En esta ocasión la macrosecuencia que, en principio, nos interesa más destaca un espacio temporal preciso, señalado por textos liminares de aniversario referidos a los años 16/17 (CXVIII) y 21/22 (CCLXXI). Puede preparar, enmarcar o centrar también tanto la crisis moral in vita (CCLXIV [Rico 1974, Santagata 1992 y Fenzi, ed. Secretum, 1992; o Galbiati 2004: 109 ss.]) como la personal in morte (CCLXVIII [Bettarini [1987b] 1998: 45 ss.; Petrini 1993: 98 ss. y 113]), que cifrará in ordine después con la CCLXX y el sonetto CCLXXI un espacio temporal y textual mayor de 249 pezzi (CXVIII-CCCLXVI) en cuanto proportio o ratio significativa. Ejemplifica, una vez más, la composición redentorista modular y recurrente: de nuevo encontramos el 153 (ó 153/154 evangélicos), número sagrado y cristiano con antecedentes aritméticos y pitagóricos que sería útil documentar mejor $^{5}$. No parece insignificante, aunque sea ahora un aspecto marginal. La cifra y su reconocimiento se convierten en elemento simbólico constitutivo y en problema formal del libro de Petrarca.

\section{El sonetto CXVIII. La huella numérica de los Salmos, la peregrinatio del Salmo CXVIII y el año 17. La conversión a los cuarenta años. El 153/154 de Agustín en la macrosecuencia CXVIII- CCCLXVI de 249 pezzi.}

Confirmado el interés de Agustín y Petrarca en el simbolismo numérico de los Salmos, será oportuno recordar que el Psalmus CXVIII «Alleluia. Beati inmaculati in via quia ambulant in lege Domini» es ejemplo destacado de interpretación simbólica, marcado por el interés de su conocida

\footnotetext{
${ }^{5}$ Armisén 2011: 20 ss. y nn. 13 y 16. Además de otras macrosecuencias de 306 unidades, señalé en 2008a: 57 la posible relación de los 31 años de su pasión amorosa (no olvidemos los tres días alegóricos de la sestina CCXIV) con el 153 de la secuencia biográfica que, en la dispositio que resulta de las postille marginales del codice, delimitan y fechan posicional y narrativamente los fragmenta CCXI-CCCLXIV. Contrástese con Pötters 1987: 85 ss.
} 
forma alfabética (Aleph / Tau) cifrada con el 22. Los preámbulos y la materia simbólica implicada en el comentario de Agustín requerirían un trabajo particular. Enarrationes CXVIII, serm. 1-32. Armisén 2012: texto y n. 18; 2013: 204.

Según he indicado, este importante Salmo CXVIII desarrolla el tema de la peregrinatio espiritual y puede leerse como destacado precedente bíblico de un componente fundamental y sostenido del componente narrativo de los $R v f$. El tema mencionado será, tras el Canzoniere de Petrarca, referente constante de la poesía petrarquista. El peregrino salmódico, en repetidas ocasiones cifrado y sostenido por la numerología de Agustín, poéticamente potenciado por los Rvf (sonetti XVI, XVII et al.) se convierte siglos después en modelo destacado, héroe del barroco y la contrarreforma. Armisén 1982: 56, 387 ss., et al.; 2004b: 71-87; 2013: texto y n. 12. Vid. infra.

Conocida ahora la coincidencia numérica y temática del sonetto CXXXVI y el Psalmus CXXXVI, que como cifra numérica he comentado en otras ocasiones (Armisén 2011: 21; y 2013: 200 ss. y 226), es oportuno señalar el interés del 118 en cuanto número con antecedentes significados en la tradición bíblica de la búsqueda espiritual y la peregrinatio vitae. En el canzoniere castellano de Boscán es ya tema recurrente y petrarquista que en los 153 versos de la final canción CXXX [102], vv. 136 ss. culmina el Libro II con el revelador motivo evangélico de la parábola del buen samaritano (Lucas, X, 25-37). Vid. infra.

La macrosecuencia CXVIII-CCLXX/CCLXXI (153/154) presenta datos textuales útiles e indicios numéricos a considerar despacio. La coincidencia numérica con el Salmo CXVIII «Alleluia / Beati immaculati in via / ...» [《Beati quorum immaculata est via»], parece relevante. El camino hacia la deseada contemplación de Dios puede ser aún largo, pero la huella de los Salmos en esa peregrinatio, ahora señalada, se hace de nuevo evidente.

La repetida atención de los comentaristas medievales al simbolismo numérico de los Salmos sí es un hecho conocido. Røstvig 1970: 50 ss. Petrarca poseía las Enarrationes in Psalmos y, como el propio Agustín era en esos comentarios muy claro sobre las dificultades de su interpretación numérica -para cuya solución, según declara, el hiponense esperaba aún recibir ayuda divina...-, el poeta toscano no pudo ignorarlo. Tampoco cabe limitarse a los comentarios de Agustín. Que Petrarca, estudioso y biógrafo de Escipión, conocía bien la numerología pagana compilada por Macrobio es así mismo evidente.

Centrémonos, pues, en datos conocidos y en los textos liminares. Tal vez sea oportuno advertir este nuevo punto de partida del sonetto CXVIII en su búsqueda espiritual o peregrinatio («Incola ego sum in terra, non abscondas a me mandata tua.»Ps. CXVIII, v. 19), en el inicio del año 17 de su pasión, que coincide parcialmente o se solapa unos meses con el año 40 de vida de Francesco ( $«$ La conversione a quarantanni: è la base del Secretum», sic. Billanovich [1966] 1996, p. 178 ss.; Pötters 1987: 81-82 et al.; Armisén 2013: 202-205). En principio, la supuesta macrosecuencia apuntada con razón por Pötters se cierra después en el sonetto CCLXXI -ya en el año 22 de su pasión por Laura, de su conflicto espiritual y su peregrinatio- con la confirmación reiterada de la voluntad de afirmarse enamorado in morte. 
El tema de la utilidad espiritual de su daño (sonetto CXVIII, v. 5: «L'amar m’é dolce, et util il mio danno,») puede también hacernos pensar en la bienaventuranza de los que lloran y sufren, punto de partida del comentario de Agustín sobre el Psalmus CXVIII (Sermo 1, 3: «beati qui plorant...»). La petición del Ps. CXVIII, v. 41 merece siquiera un recordatorio ahora: «Et veniat super me misericordia tua, Domine; Salutare tuum secundum eloquium tuum».

Los últimos versos del sonetto CXVIII confirman su condición constante con el motivo simbólico del llanto (recordemos: dolce et amarum), símbolo permanente de ese dolor y de su misma escritura (Chessa 2005: 317-319). Con el antecedente ya señalado de Confessiones (IV, 5, 10 ss), el motivo reaparece todavía en los $R v f$ con su pétrea identificación final en «l'ultimo pianto», devotamente comparado al llanto de María, 249 textos después, en CCCLXVI, vv. 111-117: «Medusa et l'error mio m'àn fatto un sasso / d'umor vano stillante: / ....». E inmediatamente, con el inicio de la última stanza, el verso 118 de la canzone «Vergine bella...» confirma (vv. 118-120) la humilitas alcanzada por el poeta caminante con una petición conocida (Armisén 2004a: 95; 2008a: 67-69; y 2013: 207 n. 10, 211 et al.), cifrada numéricamente a 17 versos del final:

Vergine humana et nemica d'orgoglio, del comune principio amor t'induca: miserere d'un cor contrito humile.

Recordemos lo señalado en el 2004: el primer miserere marcaba desde el sonetto LXII «Padre del ciel...» de la prima preghiera el inicio de una macrosecuencia de 306 fragmenta (153x2 [ó 17x17+17]) Armisén 2004a: 89; 2008a: 52 ss. El necesario rechazo del orgullo y la exaltación de la verdadera humildad, como el mismo tema de la vida, camino hacia Dios o peregrinatio (Chessa 2005: 92, 216; Ego sum via [Juan, 14, 16] Enarr. CXVIII, 6, 3), son componente necesario de los primeros sermones de Agustín sobre el Psalmus CXVIII. Según Chessa, los del hiponense no son tampoco los únicos comentarios a valorar. Pero la presencia dominante de motivos simbólicos conocidos en los últimos versos del Canzoniere se apoya también en posiciones marcadas y con números conocidos, verificables en texto literario y codice.

Como digo, sin perder de vista la huella señalada del Psalmus CXXXVI en el sonetto CXXXVI de los $R v f$ (Armisén 2011: 21; y 2013: 232, n. 22et al.), atender a la presencia operativa de la lectura numérica de los Salmos parece oportuno. Los números de los Salmos reaparecen en la obra del poeta toscano donde son frecuéntemente evocados, utilizados con intención en diversos momentos. Su coincidencia frecuente con la numerología cristiana de Agustín viene a probar de forma circunstancial pero consistente el interés de ambos numeri aeterni en la poesía de Petrarca ${ }^{6}$. La relación del sonetto CXVIII en que se inicia el año 17 y la canzone della Gloria, CXIX, con la que ofrece perceptibles

\footnotetext{
${ }^{6}$ Considerar por analogía y de forma simplista los números de los Salmos y otros textos bíblicos (Evangelio de Juan, etc.) y/o los números paganos fundamentales integrados y cristianizados en la obra de Petrarca como números eternos es una propuesta de lectura. Agustín, en principio, usa los numeri aeterni para referirse a la Creación Universal (Harmoniae aeternae) y al anima (Harmoniae animae), Correa Pabón 2009: 170-176 y 158-169, respectivamente), referentes, arquetipo divino o primer modelo del artifex y modulator. Sobre los numeri aeterni... vid. De musica, VI, 9, 23 ss.; y VI, 12, 34 ss. También Correa Pabón 2009: 170-189.
} 
contrastes (Santagata 2004: 546-547), marca el inicio de un año significativo y otra macrosecuencia reveladora de 249 unidades que debemos revisar ahora.

$\mathrm{Si}$, de acuerdo con lo más obvio, podemos reconocer con Bettarini ([1987] 1998: 78 ss.) que el CCLXXI es un fechable «sonetto di anniversario, messo là come indizio di celebrazione», puede que ésa no sea con los años su función compositiva más relevante en los $R v f$. Muy probablemente, como dovela chiave, el sonetto señala en la posición 154 del total final de 249 una intersección con medidas precisas y proporciones reconocibles -la famosa media y extrema razón...- de la macrosecuencia que desde el inicio del año 17 completa el libro de rime sparse.

La macrosecuencia particular CXVIII/CXIX - CCLXX/CCLXXI (Armisén 2004a: 93-94; 2011: 12; y 2013), delimitada por las dataciones de los aniversarios dieciséis y veintiuno, ambos ya cumplidos, se presenta solo implícita, señalada numérica y posicionalmente; pero se hace significativa $\mathrm{y}$, finalmente reconocible, se desvela al lector atento de los comentarios evangélicos, conocedor interesado de la exégesis de Agustín sobre la pesca milagrosa como cifrada numéricamente por el 17 y el 153 .

Una cifra evangélica muy conocida que en el codice Vat. lat. 3195 -la composición numérica es forma constitutiva de la secuencia...- establece y marca primero el período temporal que se inicia con el decisivo año diecisiete de su aventura amorosa: «La conversione a quarant'anni è solo un momento della più vasta e impegnativa finzione di cui il "Secretum" è il cardine» (Santagata 1992: 191). En principio, se completa (textualmente formalizada por la cifra del 153/154 redentorista del Evangelio) en el veintiún aniversario cumplido, con ese año 22 que se inicia pronto, tras la muerte de Laura reconocida en el sonetto CCLXVII. Son cifras (numeri aeterni) que apoyan también la prevalente lectura espiritual del caso.

Como he venido señalando desde el 2004, la huella numérica de Agustín no tiene presencia ocasional, única o casual en el Canzoniere. El sistema numérico del hiponense provee información pertinente, se convierte en perceptible forma repetida, intencional, de reconocimiento obligado en la lectura de la composición del libro. Porque el poeta enamorado se afirma formalmente con su misma transformazione, explícitamente declarada con énfasis posicional, doblemente apoyada antes con el 153/154 en el v. 14 del sonetto CCXIII de las «Gratie ch'a pochi il ciel largo destina»-verdaderas formas orgánicas operativas, las actualizadas con el verso 56 del fol. 42 recto y en las sílabas 153/154 del sonetto mencionado (Armisén 2008a: 64) - confirmada en los poemas finales de la gran secuencia de il riscatto de 306 fragmenta (LXI-CCCLXVI [153+153]). Y la presencia de la influencia divina, de la caritas aludida en el sonetto CCLXVI con el doble aniversario (15+18), cierre de las rime in vita,

\footnotetext{
${ }^{7}$ Tomo la distinción moderna entre forma abstracta (estabilizada, regular...) y forma orgánica de la crítica literaria de los años 30 y de Herbert Read, Form in modern poetry (1932) en particular. En [1991] 1995, 1998: 143, 1999, [2005] 2007 y [ 2009] 2010: 9 comenté su influencia, desde 1956 por lo menos, en la poesía de Jaime Gil de Biedma (1929-1990) y otros poetas de su generación: más precisamente, su significativa relación con el cifrado exorcismo político e histórico de la importante sextina «Apología y petición» ([1960], Cuatro poemas morales, 1961 y Moralidades, México, 1964), con «Ampliación de estudios» y otros textos del poeta barcelonés. Armisén 1999: 44 ss., 72, n. 32, 117, 140 y n. 125.
} 
cifra y loa simbólicamente la condición positiva de ese amor ya antes de la muerte de Laura (Armisén 2008a: 52 ss.y 63-64; 2011: 12 y ss.; 2013: 210 n. 3, y 218-220; 2015...). Contrástese ahora con Stroppa 2014: 234-241.

\section{La ratio aurea de los Rerum vulgarium fragmenta y sus implicaciones espirituales. Muerte de Laura y Providencia: la corregida canzone CCLXX y el sonetto CCLXXI.}

El año 17 que suscitó la mención enfática de Augustinus en el Secretum (III, [137], ed. 1992: 206), en el sonetto CXVIII referida en principio al cumplido décimo sexto aniversario de su pasión por Laura -y a sus proféticos antecedentes paganos-, ha merecido en el pasado la atención de otros poetas y estudiosos. Aunque todavía regularmente ajenos a las propuestas exegéticas de Agustín sobre ese número primo y su relación con el 153+1 del Evangelio de Juan (XXI, 1-14), tras las observaciones apuntadas en los comentarios del siglo XVI y las ediciones modernas, «Rimansi a dietro il sestodecimo anno» interesó por otras razones en la relación del Canzoniere con el Secretum a no pocos estudiosos. Atendiendo a su interés en la narración biográfica y en el sistema de aniversarios, fue destacado como momento cardinal de la composición del libro de poesía vulgar por W. Pötters (1987: 51 ss.; 63 ss.; 85 ss.). Sin entrar en la evaluación última de todas sus particulares propuestas de lectura numérica de los $R v f$ que, en ocasiones y en los términos en que las presenta, puede ser difícil compartir, será oportuno, como adelanté ya en 2004, volver sobre alguno de los planteamientos, detalles relevantes y lecturas aritmológicas más útiles del profesor de Würzburg.

Porque, después, esa misma secuencia unitaria de 153/154 fragmenta que concluyen la canzone CCLXX y el sonetto CCLXXI se integra significativamente en la narración y en la suma del total numérico subsiguiente con forma y función que creo significativas. Discretamente, desde el sonetto CXVIII que señaló el inicio del año 17 hasta la canzone CCCLXVI, con una proporción que semeja de nuevo ajustada por ratio perceptible, tras la muerte de Laura, sostiene y confirma en términos de macrocomposición (249:153/154...) las consecuencias del sentido espiritual de su amor in vita e in morte.

En mi opinión, la macrosecuencia iniciada en el sonetto CXVIII (y acabada con el final del Canzoniere) resuelve formalmente, con la composición proporcional de ratio conocida y en clave agustiniana, un problema central del Canzoniere; y establece en el dictus (De música libri VI, lib. I, 11, 18; Correa Pabón 2009: 68), con la famosa ratio aurea, una de las macrosecuencias dominantes, finales y conclusivas de los $R v f$. El sentido unitario de las rime sparse se hace evidente. Interesa percibir la transformación -transformazione reconocida con el perspectivismo propio de la confesión autobiográfica retrospectiva-, adelantada al lector en la sucesión de acontecimientos narrada y rememorada en tiempo de escritura con la loa de Laura en el CCXIII, v. 14; anterior también a su pérdida, conocida desde el sonetto CCLXVII, «primo testo in morte».

Estudiar la recuperación cifrada por el año 17 de su pasión y el 40 de vida, reiniciada con nueva fuerza in morte después y señalada con énfasis en CCLXX, CCLXXI, CCLXXII parece ahora obligado. Es tan importante como verificar el interés simbólico de la ratio y la huella numérica de 
Providentia, introducida ya como tema con el nacimiento de Laura en el sonetto IV. Armisén 2004a: 83-84; 2008 a: 58 ss., nn. 6 y 7; y 2013: 227.

Con el recuerdo de la condición figurada de Laura, destacada en el sonetto «Que' ch'infinita providentia et arte» que cierra armónico $(1+2+3+4)$ la primera página del «codice d'autore», tengamos, pues, presente lo señalado sobre el valor y límites de Fortuna en CXVIII, vv. 5-8; o -más relevante ahora- sobre las correcciones textuales y el valor último de Morte en la canzone CCLXX (Armisén 2004a: 89 y 93-94) que supone el triunfo de Providencia, inmediatamente destacado por el sonetto CCLXXI. El sentido providencial de esas muertes (si aceptamos hablar de dos...) lo establece la medida composición, nos lo confirma su forma numérica.

No faltaban lectores conocedores de la cifra evangélica y de la exégesis de Agustín sobre el 17 $\mathrm{y}$ el 153. Pudieron, tal vez, leerlas y entenderlas como operativas, siquiera fragmentaria $\mathrm{u}$ ocasionalmente, en el texto de los $R v f$. En todo caso, los problemas que todavía hoy plantean la función de Laura, la existencia después de una nueva tentación femenina -con antecedente en la Vita Nuova de Dante- y el enigma subrayado con la doble acción de Morte (Santagata 1992: 198; 205 ss.) parecen ahora significados o resueltos por la composición y sus razones. Encuentran una vía de solución formal en los $R v f$, si atendemos a la posición relativa del conocido como enigmático sonetto CCLXXI del fol. 56 recto; y, más precisamente, a la declaración ahí de sus tres últimos versos, localizada con voluntaria intención posicional en la macrosecuencia mencionada.

Pero hemos de reconocer que tanto la materia numérica integrada, operativa según vemos en texto literario y codice, como la armonia de la macrocomposición o sus razones casi nunca fueron objeto de interés explícito en las espositiones del siglo XVI. Armisén 2011: 29-30. Al menos hasta donde las conozco, aunque interesadas en otros temas como la lectura biográfica y localización personal o espacial de Laura y el Sorga, ignoran el problema formal que estudiamos.

La distancia de 249 pezzi que restan en el texto, desde el inicio del sonetto CXVIII con el comienzo del año 17, marcado ahí también por la reaparición del temor anterior de que la muerte de Laura le preceda (Secretum: III, 138; Armisén 2008a: 49-51; 2013: 210 ss.), y medida que después formalizará como total el final último de los $R v f$, puede y parece haber sido ajustada con ratio significativa. La paradójica afirmación «L'amar m’é dolce, et util il mio danno» en su v. 5, mencionada aquí como posible huella del comentario de Agustín sobre el Psalmus CXVIII, señala y refuerza el componente críptico de la premonición. La cifra redentorista (153/154), que desde ese sonetto sostiene la paradoja explícita de la providencial muerte de Laura, permite reconocerlo.

La canzone CCLXX -texto en que el poeta enamorado, rechazando nuevas tentaciones amorosas que amenazan con devolverlo al «giogo antico» del dios Amor, se afirma in morte de nuevo en su pasión laureana: pide a Amor que recree a Laura, que la vuelva a la vida, vv. 13 ss. (ed. Bettarini 2005: 1219 ss.; Praloran 2007: 107 ss.) - asume también, quizá, cambios de expresión o stile (M.S. Sapegno 1999: 65). Creo que Petrarca alcanza un medido contraste, buscado contrapunto que focaliza o realza la situación, que acompaña la revelación final de Morte propuesta en términos de ratio. 
Con las correcciones introducidas y su ampliación de cuatro a siete estrofas (ed. Santagata 2004: 1097) -tengamos muy presente el interés del texto para la lectura providencialista y posterior de Boscán en su canzoniere castellano (Armisén 2004a: 86-90, en particular 89)-, el valor temático retrospectivo se acentúa en cuanto examen o revisión de la anterior dependencia al dios tirano -cual metamorfoseado, nuevo Acteón- con la reafirmación in morte de su rendida voluntad anterior, las gratie de Laura del CCXIII evocadas ahora en términos de «laccio d'or», añoradas todavía como armas de Amor (estrofa V, vv. 61-75). Y la posición de la canzone «Amor, se vuo' ch'i' torni al giogo antico» se impone, nos lo confirmará. Porque las importantes correcciones establecen la importancia y origen de su Spes y confirman la condición positiva de su pasión (estrofa III, vv. 31-45). Tras esas siete estrofas, la función determinante y decisiva de Morte la subrayan conclusivos los tres versos finales.

La marcan como objeto de particular atención en fechas discutidas, probablemente pertinentes en el proyecto de composición del libro. Santagata ed. 2004: 1097-1099. Mediante la transcripción en el códice autorizado, su localización y su lectura in ordine quedará ajustada con el sonetto CCLXXI del veintiún aniversario (ed. Bettarini 2005: 1235) y con la conocida cifra numérica de Agustín a una proporción pitagórica muy conocida ${ }^{8}$.

Hemos de valorar tanto la relevancia del importante año 17, iniciado por el sonetto CXVIII de los Rvf, como las conocidas e importantes correcciones del texto de la canzone CCLXX; también el precedente conocido de la Vita nuova en lo relativo a una segunda opción amorosa; o incluso, con otra cronología, distinto contexto y otra perspectiva, la posible incidencia posterior de la akrasia en la canción CIII [75] de 154 versos del canzoniere de Boscán (Armisén 2004a: 85-91; Williams 1996: 34 36) y en otros textos posteriores del Libro II de 1543 (p.e. soneto CXXVII [99] en el que alcanza la condición de parálisis con el referente reconocible del milagro evangélico; o finalmente en la canción CXXX [102], vv. 136 ss.)

\section{Otras lecturas y lectores del 17 y el 153 de Agustín y Petrarca. Las cifras evangélicas recuperadas. Los grabados CXVIII / CXIX en las Evangelicae Historiae Imagines del P. Jerónimo Nadal. El peregrino del P. Baltasar Gracián, sus criaturas y la cifra de El Criticón.}

Antes de 1542, en fecha imprecisa, el poeta barcelonés Boscán, según he advertido, cifra en los últimos 17 versos de su canción final de 153 versos -reincidiendo en el tema salmódico de la peregrinatio vitae que acabó la canzone CCCLXVI «Vergine bella...» de 137 versos- un cierre marcado por el referente conocido de la parábola evangélica del buen samaritano (Armisén 1982: 399411; 2004a: 79-81 y 86-87). Y según vemos, como señalé (2004b: 71-82), el motivo reaparece,

\footnotetext{
${ }^{8}$ El interés de la canzone CCLXX y el sonetto CCLXXI en la macrocomposición de los Rvf ha sido descuidado regular y casi generalmente por sus comentaristas, pese a la atención de W. Pötters desde 1984 y 1987. La estrecha relación temática y funcional de ambos textos queda poco menos que anulada por la segmentación en dos secciones distintas y en trabajos diferentes en la reciente compilación de Lectura Petrarcae Turicensis, aunque con razón la menciona y revisa brevemente Fenzi en la página inicial de su aportación de 2007: 595 ss.
} 
ajustado con el mismo sistema numérico presente en los $R v f$ de Petrarca, reutilizado por Boscán en el Libro II de la edición póstuma de 1543 y en su composición final.

Será después aplicado con intención en los 153 grabados+1 de portada de las Evangelicae Historiae Imagines (Antwerp, Cristobal Plantin, 1593) del P. Jerónimo Nadal (1507-1580). Según advertía en 2004, la figuración de la gratia en relación con el tema de la peregrinatio y el buen samaritano la cifra Nadal en el grabado 33 de sus Imagines..., CXXXVII del ordo litúrgico (Cif. Biblia Natalis 2008: 92-93).

La lectura de la composición numérica del Libro II de Boscán, pese al sorprendente, terco e ignorante silencio de sus editores y algunos estudiosos recientes, permite desde 1982 y 2004, advertir en el importante texto de 1543, muchas veces reimpreso en el XVI (próximo y accesible, muy conocido...), la adecuación y presencia activa de las cifras implicadas, que reaparecen también incuestionables -cifra total y alguna posiciones...-, años después, en la composición simbólica de la «vita Christi» del jesuita mallorquín.

Como texto concebido para la evangelización y la meditación espiritual practicada por la Compañía de Jesús, su difusión e influencia no plantean dudas. Lo considero una prueba, no la única, de la operatividad del mismo código durante bastantes años. El P. Nadal podía muy bien leer el sentido espiritual o la intención simbólica de los 102 componentes del canzoniere de Boscán. Debía reconocer e interpretar, con facilidad obvia, significado y forma numérica en los 153 versos de «Gran tiempo Amor me tuvo de su mano», CXXX [102], canción final de 1543. Importa recordar que el 102, total del canzoniere castellano de Boscán, tantas veces reimpreso, reaparecía como cifra significativa en el número de grabados del llamado Catecismo visual de Pedro Canisio S.J. (Antwerp, Plantin, 1582) Armisén, 2004b: 76 y n. 15.

La influencia formal de los canzonieri en el programa de Nadal sobre la vita Christi no debe rechazarse sin una consideración previa, interesada y más atenta. Podría, quizá, incluso tratarse de una relación o influencia directa del mayor interés ahora. Amigo y, con el tiempo, discípulo de Ignacio de Loyola (Azpeitia, 1491-París, 1556: conocido en vida como el peregrino), el sacerdote mallorquín pudo (tal vez, debió) tener muy presente el canzoniere de Boscán de 102 componentes y conocía el Canzoniere de Petrarca cuando, tras la elaboración de varias series de dibujos, años de dudas sobre los impresores y los ajustes y las discusiones propias de un proyecto de la Compañía concebido mucho antes $^{9}$, ajusta y decide finalmente el ordo plural y las cifras de los 153/154 grabados que, consciente de la importancia del proyecto, ha meditado y cuidado durante años.

El proyecto original de las Imagines surge en las inmediaciones del mismo Fundador, queda documentado pocos años después de su muerte y, quizá, contaba con su aprobación previa. La publicaciones de Canisio y Nadal se producen algunos años antes de la beatificación (1609) y posterior

\footnotetext{
${ }^{9}$ El primer proyecto de las Evangelicae historiae imagines fue asumido por el P. Francisco de Borja que con su nominación al Generalato de la Compañía (1565) lo deja en manos de Nadal en 1566. Sobre los avatares y cambiantes circunstancias del mencionado proyecto, véase Rodríguez G. de Ceballos [Nadal ed. 1975]: 9 ss.; y Dekoninck, 2005: 170-178.
} 
canonización de Ignacio de Loyola (1622). Un Peregrino al que reconozco, años después, como referente remoto, antecedente velado o modelo en el último guía de El Criticón (1657, III, crisi 12) que acompañará finalmente a Andrenio y Critilo en el paso a la Eternidad. Los 33 méritos rubricados confirmaban el velado componente autobiográfico con el referente modélico de la vita Christi, sostenido en su significado personal intimo por las 38 crisis completadas y publicadas, pese a todo, en 1657. Será oportuno no perder de vista el interés de destacados miembros de la Compañía de Jesús en la criptología numérica. Baltasar Gracián trabaja códigos conocidos y directamente accesibles.

Pero creo también que el referente directo inmediato o más próximo (y provocador) del personaje alegórico final de El Criticón podría ser, en esa ocasión, el propio autor aragonés. La pretensión de incluirse en la propia obra no era solución nueva. Puede leerse apoyada por la cifra númérica y autobiográfica de la secuencia de 38 crisis. El Modelo general y último del Peregrino, reconocible como guia y protector para no pocos lectores del libro (prohibido al P. Gracián por sus superiores antes de su publicación), aparece, reaparece y surge acompañante de Andrenio y Critilo en el tránsito final. $\mathrm{Si}$, con alguna razón, puede leerse como referente velado del verdadero autor, sostenido él mismo por su obra y con el aval de sus 38 años de milicia, lo leo mejor como personificación alegórica jesuítica en el trabajado final destinado a la interpretación, una forma de autoafirmación medida, que va más allá de la mera referencia personal, pretenciosa y sin duda cuestionable para más de uno.

El Peregrino se ofrece al lector en la Crisi 38 de 1657 como última clave por resolver en la sucesión numerosa de guías y emboca al lector de la alegoría en la ineludible, necesaria percepción del componente autobiográfico de El Criticón. Encontramos y leemos el artificio como discreta y humilde invocación, una propuesta insinuada y velada de mediación del fundador, santo y héroe modélico, la última provocación retórica y devota del autor, destinada también a confundir y frenar a sus detractores pasados.

Baltasar Gracián, será avalado en 1657 por los 38 años de militia Christi desde su ingreso, novicio en la Compañía de Jesús, el 30 de mayo de 1619. Que los lectores modernos ignoren y desconozcan esos datos parece casi natural, pero son hechos relevantes en una lectura interpretativa, rigurosa e histórica de El Criticón. Tras la inédita comunicación de 1992 en Alcalá, más oportuno hubiese sido plantearlo con espacio en Zaragoza el 2004 (Armisén 2010: 20 y n. 5).

La búsqueda de lo admirable ejemplar es el tema central, pero lleva su trabajo. Tiene como fiel y natural compañero el desengaño. Con mejor criterio, evitaré hoy la impertinencia gratuita de fechar en el 2014 estas propuestas circunstanciales en dia supuesto y lugar inoportunos. Si la concepción universal del libro del jesuita se hace pronto perceptible, reconocer y valorar la influencia del círculo próximo a Gracián y sus lectores inmediatos no tiene nada de inútil o baladí, excede los límites de nota. Frente al académico silencio, sí resulta obligado insistir: es justo y, me temo, parece todavía necesario.

La defensa de lo admirable ejemplar más allá de lo verdadero o verosímil permite reconocer que su rechazo del realismo no ejemplar, que hemos vinculado con sus críticas al Quijote cervantino, suponen también la defensa teórica de su propia práctica oratoria. 
Como sus personajes lo hacen con el índice final de 33 méritos rubricados ante el Mérito, aunque más discretamente, el autor se presentaba reconocible para numerosos lectores próximos Societatis Iesu, señalado por esas 38 crisis que [13+13+12] dan forma biográfica medida y significado personal al texto. Estamos ante una clave final, un ejemplo con antecedentes, una lectura formal construida en la tradición alegórica de la tipología bíblica y las figurae. Vid. Armisén 1986: 238-242; 2004b: 97-98 y nn. 33 y 37.

La intencionalidad de esas cifras en la obra de Gracián, motivado profesor de retórica y orador religioso cuestionado, censurado y castigado en la propia Compañía, confirma la interpretación y ha de suponerse - «el curso de tu vida en un discurso...»- como perceptible (más bien evidente) para los lectores próximos e iniciados, conocedores de esa vida y de sus fechas personales, atentos a sus circunstancias y problemas.

Las criaturas del universo mundo verbal y alegórico dan forma irrenunciable al reto per sonal del jesuita de Belmonte. Leer El Criticón con el eje conceptual que revisé en 1985 de la admiratio (los famosos mirabilia y los madrileños engaños de Falsirena o los frágiles, cuestionábles, falsos méritos de tantos pretenciosos: «maravillas caducas», «diphtongos del engaño» u «hombres tintoreros», et $a l . .$.$) , un tema estético y ético culminado en la novela alegórica con la búsqueda última de «lo$ admirable ejemplar», pese a todo lo escrito, hoy sigue siendo tarea útil. Cualesquiera que sean los motivos, ignorarlo es ya, en mi modesta opinión, un error de lectura. Armisén 1986: 216 ss.; 228 ss. y 236-242.

En 1545 Nadal realiza los ejercicios espirituales e ingresa en la Compañía de Jesús. No dudo tampoco que el P. Jerónimo Nadal S. J., muchos años antes de 1580 -como el propio fray Luis de León O. S. A.-, pudo fácilmente entender la función simbólica del motivo evangélico en los 17 últimos versos del canzoniere de Boscán ${ }^{10}$. Hombre culto, teólogo y matemático formado en Alcalá y Paris -donde conoció a Íñigo López de Recalde-, minucioso y exacto, lector de poesía, tuvo que reconocerla ahí casi necesariamente después de 1543, valorando su integración funcional en los 153 versos de la canción CXXX [102], cierre y explicación espiritual del primer canzoniere castellano impreso. Armisén 2004b: 80. Entiendo que la presencia de la numerología de Agustín en el Libro II de 1543 es un antecedente más que probable (y muy directo) de su aplicación posterior en los 153+1 grabados de la «vita Christi» del P. Jerónimo Nadal.

\footnotetext{
${ }^{10}$ La decisión de Jerónimo Nadal de situar antes de su muerte en 1580 los dibujos previos sobre la pesca milagrosa de Tiberíades con los 153/154 grandes peces (y los grabados que realizaría Wiericx después) en las posiciones 144/CXVIII y 145/CXIX de las Evangelicae Historiae Imagines muestra, probablemente -ahora solo en los números romanos del ordo litúrgico-, el interés del jesuita mallorquín en esas cifras que pudo, quizá, reconocer ya antes, cifradas repetidamente también por el 17 en el Canzoniere. El grabado 33/CXXXVII nos revelaba la identidad simbólica del buen samaritano (Lucas, X), motivo que trabajó Boscán con intención numérica reconocible en el cierre de su canción final de 153 versos: CXXX [102], vv. 136 ss. Como Nadal aplica una doble numeración -en romanos (dispositio de las E.H.I. de 1593 según el calendario litúrgico vigente); y arábigos (sucesión de su disposición en el texto preparado por Nadal)-, el milagro del Evangelio de Lucas (V, 1-11) ocupa la posición 17 en el orden de 1593 (ó CXXXI de la dispositio, en romanos). Con ello, en mi lectura de las E.H.I. al menos, ese 17 cifra también el ordo dispuesto por Nadal del acontecimiento milagroso, narrado por Lucas in vita. Más allá del texto evangélico, la atención del jesuita al devoto cierre mariano de las Imagines merece así mismo atención.
} 
En los finales del siglo XVI, Nadal ejemplifica el interés en la composición narrativa de la numerología cristianizada por Agustín y su aplicación. El antecedente de la búsqueda espiritual de Petrarca y el canzoniere redentorista de Boscán difícilmente pudieron serle ajenos por todas las razones. Su forma numérica, como vemos, no era tampoco inaccesible para el jesuita, él mismo interesado practicante años después en la composición narrativa y cifrada de la vida de Cristo con esos mismos números. También la relación simbólica del sonetto CXVIII y la canzone CXIX de Petrarca con el año 17 y el 153 de Agustín pudo ser de alguna manera conocida o reconocida por Jerónimo Nadal siglos después ${ }^{11}$. Leemos textos de una tradición numérica bíblica y cristiana en la que las coincidencias no parecen gratuitas y reaparecen con intención presumible. El interés del jesuita en la simultaneidad secuencial de la composición pictórica medieval ( fragmentación» sic. G.. de Ceballos [Nadal, ed. 1975]: 12; D. Bauer 2012: 1 ss. y 8 ss. ) no impide reconocer su coincidente atención a las posiciones y formas numéricas que cifran el sentido de algunos textos en las formas narrativas de Petrarca.

Hemos de valorar seriamente esa posibilidad, siquiera aventurada, pero marcada en el Canzoniere por el componente sentimental, espiritual (o en ocasiones penitencial [incluso como «laberinto» o ergastulum]) de la sagrada, ritual meditación poética (la situación poética), en no pocos poemas anterior y tantas veces próxima en su génesis a la compositio loci. Y no faltan coincidencias numéricas que podrían apoyar esa hipótesis de la relación directa con los Rvf, dado que Nadal reserva las posiciones CXVIII y CXIX de su trabajado libro (numeración litúrgica en romanos) para los grabados sobre la pesca milagrosa del Evangelio de Juan. No olvidemos tampoco, junto a la biográfica y agustiniana autoinculpación confesional, el antecedente numérico davídico.

En todo caso, en las Imagenes... encontramos formas de aplicación ocasional y reiteradamente significativas que -como las breves notas latinas que complementan y orientan (o incluso suplementan) persuasivos detalles devotos más allá del texto bíblico- ofrecen posibilidades al magister, guía espiritual que dirigirá la meditación para la que esa macrosecuencia visual y ritual ha sido concebida y ordenada. La confesión general final de los Ejercicios rige o dirige un proceso espiritual conocido.

Los 153 grabados (+1 de portada) sostienen la lectura simbólica, actualizan un código numérico activo, accesible para iniciados, tal vez reservado para los avanzados, pero conocido, frecuente en círculos interesados en la espiritualidad, perceptible en los comentarios del milagro evangélico, con huella reconocible en los Ejercicios y la famosa compositio loci. Que otras secuencias de grabados

\footnotetext{
11 Además de la condición del 119 como múltiplo de 17, el interés de Petrarca y Sannazaro por el año 17 serán datos relevantes para lectores interesados en la numerología de Agustín. No puede extrañarnos que la primera pesca milagrosa de Lucas, V, fechada en el año 31 de Jesús, sea representada en el grabado 17/CXXXI. Nadal busca apoyar la lectura y explicación de sus Imagines con cifras, aprovecha las posibilidades ocasionales de su plural ordenación. Estamos en una tradición numérica evangélica que se nutre de los comentarios más conocidos, que podemos documentar e interpretar con la summa evangelica de Ludolfo de Sajonia. Armisén 2004a: 79; y 2004b: 69 ss. Más difícil será señalar los límites del reconocimiento que llegaron a alcanzar el Padre Jerónimo Nadal S.J. y los círculos del Collegio Romano (fundado en 1551) de la búsqueda espiritual y la composición numérica de Petrarca en los Rerum vulgarium fragmenta. Como veremos, el interés por el simbolismo numérico puede verificarse incluso en los Ejercicios Espirituales de Ignacio de Loyola. Sobre las fechas y estadios de su redacción, vid. «Introducción general» de D. López de Tejada a Los Ejercicios Espirituales de san Ignacio de Loyola, [1998] 2002: 23-26.
} 
jesuíticos posteriores apoyen la aplicación biográfica de la «composición viendo el lugar» y/o las meditaciones de Ignacio, aunque permiten conocer datos muy útiles sobre cifras de interés, no cambia mucho las cosas (Dekoninck 2005: 178; Bauer 2012: 3 ss. ${ }^{12}$ ). La preciosa, muy accesible edición fotográfica bilingüe de 2008 de la Biblia Natalis facilita hoy su verificación y la necesaria lectura directa de las Imagines.

Conocido el coincidente interés en la composición numérica cifrada con el pensamiento de Agustín, la relación de los Rvf de Petrarca con los Ejercicios espirituales de Ignacio de Loyola y su famosa composición de lugar merecería un estudio particular. Armisén 2004b: 71-82 et al. No faltan otros indicios de la atención de la Compañía de Jesús a la poesía espiritual y a la del Canzoniere en particular ${ }^{13}$.

Desde su publicación en 1593, los dos grabados de Wiericx sobre la pesca milagrosa de Tiberíades (Juan, XXI, 9-13) incorporados entre los 153+1 del libro de Nadal, una vez corregida la evidente errata de impresión del primero que solo afecta a su numeración en romanos, de hecho ocupan en el orden litúrgico las mencionadas posiciones 118 y 119 ${ }^{14}$. Armisén 2004b: 73-75, 99 y 100. Sin salir del mismo código numérico que localizo y estudio en los Rerum vulgarium fragmenta, muchos años después, se confirma todavía el interés reiterado de algunas relevantes cifras y posiciones en espacios textuales destacados.

Y no es tampoco el único dato a considerar. Entre las 153 esculturas del colonnato, piazza retta y fachada de la basílica en la Piazza di San Pietro, obra diseñada finalmente por Gian Lorenzo Bernini y acabada antes de la muerte de il cavalier en 1680, la escultura del Fundador de la Compañía, canonizado el 22 de mayo de 1622, ha sido situada en una posición calculada, decidida antes de 1656 muy probablemente o poco después.

$\mathrm{Si}$, entrando en la plaza, leemos el espacio desde la izquierda, tras la 136 de san Bernardo y la 137 de san Benedicto (que no cabe ignorar: sería la 17, leyendo desde la derecha), san Ignacio ocupa

\footnotetext{
${ }^{12}$ La atención de la Compañía a lo numérico ofrece ejemplos reiterados y significativos. Armisén 2004b. Aunque pueda parecer anecdótico, con el recuerdo de «Se Virgilio et Homero avessin visto» («sonetto153», el Rvf CLXXXVI del 56 de Augusto y Escipión), no renuncio a advertir de nuevo que el número de los grabados de la Vita Beati P. Ignatii Loiolae, (Anvers, 1649 et al.), siquiera parcialmente atribuídos al joven P.P. Rubens, tras su primera aparición (Roma, 1609), alcanzó en las reediciones de la segunda mitad del siglo XVII el total de 56 grabados, numerus plenus de Ciceron, conocida cifra de héroes y de profecías, antes referida a Escipión o Augusto (Macrobio, In Somnium Scipionis; Rvf, sonetto CLXXXVI; Armisén 2014: pendiente de publicación). Vid. Dekoninck, 2005: 179-180.

${ }_{13}$ Véase al respecto la descripción del que Rodríguez Moñino tituló Cancionero de Jesuitas en su artículo «Tres cancioneros manuscritos (Poesía religiosa de los siglos de oro)», Ábaco, 2, 1969, pp. 127-272.

${ }^{14}$ El grabado de Wiericx, que desde 1593 ocupa la posición CXVIII (numerado en su ordo litúrgico en romanos como XCVIII por verosímil error de imprenta: los dos primeros números han cambiado su posición), trata una sucesión de momentos de la llegada de la barca, con Jesús asando ya el pez que trajo consigo y con los discípulos arrastrando los 153 grandes peces a la orilla. El inmediato grabado CXIX (ó 17x7) se centra en la instauración de la Eucaristía, la Iglesia y su proyecto de evangelización: Jesús y seis discípulos con el primer pez ya en la mesa y el séptimo discípulo preparando en las brasas alguno de los pescados por ellos. He reproducido ambos grabados en Armisén 2004b: 99-100. El elaborado Evangelio de Juan lo sitúa, con énfasis comentado por Agustín, como última de las apariciones in morte, mayor y último milagro (sic. Agustín). Armisén 2004b: 74. Los cuidados grabados de las Evangelicae Historiae Imagines de Nadal, impresos en 1593 y reeditados en fechas recientes, son hoy accesibles en edición on line como $p d f$ y en varias ediciones impresas.
} 
la posición 138. Ibid: 95 y n. 36. Considerando la figura de Jesús, destacado en el centro de los apóstoles y sobre la fachada de la basílica - volviendo ahora sobre el «error mínimo» sospechado (y rechazado) en el 2004-, podemos también leer la discreta cifra numérica posicional de Ignacio como 137 ó 16 desde la derecha: un caso más de 136+1 tal vez, en una lectura parcial que dejase a Cristo resucitado y central fuera de cómputo. Es un indicio del momento histórico de la Iglesia romana. Armisén 2004b: 86-87. No dudo que la disposición, el ordo y numero de las esculturas fue meditado, quizá debatido y desde luego calculado en sus significativos detalles.

Creo que las coincidencias señaladas merecen atención. Con ellas, la posible huella directa que he comentado de la forma numérica de los libros de Juan Boscán y/o Francesco Petrarca en la composición de las influyentes Imagines de Nadal debe ser al menos considerada. El mallorquín había concebido, anotado, controlado y ordenado los diseños de los dibujos realizados en su mayoría por los italianos Bernardino Passeri y (quizá, tardíamente) Giovanni Battista de Benedetto Fiammeri, jesuita florentino que ingresa como novicio en 1576. Nueve dibujos son de Martin de Vos y uno tardío de Jerónimo Wiericx.

Si no existe otro antecedente directo de la composición iconográfica de Nadal que comparta o explique mejor las coincidencias numéricas que advierto con los $R v f$, los precedentes de Agustín y la tradición petrarquista que estudio permiten una interpretación plausible que reclama atención.

\section{El año 17, el sonetto CCLXXI y la función de Muerte en los $R v f$. La numerología pagana cristianizada. Aritmética y geometría a lo divino: el 153 de la raiz cuadrada de tres $[\sqrt{ } 3]$ en el vesica piscis cristiano. Peregrino hacia las formas numéricas de lo sagrado: la Piazza di San Pietro.}

Regresemos primero al Canzoniere. El enigma de la liberación alcanzada en los $R v f$ con la doble acción de Muerte en el cierre de la canzone CCLXX vv. 106-108 y el sonetto CCLXXI vv. 12-14 se presenta explícitamente destacado en ambos textos de Petrarca.

Recordemos al menos la observación de Roberto Antonelli (1992: 407):

Da 271 alla fine il tempo cessa di essere scandito: ormay il breviario spirituale organizzato da Petrarca si può concludere con se stesso, ovvero con il 1358, ultima data sposta, coincidente con la fine della parabola...[...] (364, vv.1-7).

De acuerdo todavía con las introductorias propuestas de 2004, ambos casos particulares ayudan a entender ahora la precisa y excepcional coincidencia de otras fechaciones de aniversario con límites exactos inicial y final de la cronología biográfica explícita, amorosa o espiritual integrada en la forma compositiva de los $R v f$. Hoy parece más relevante, con la presencia activa conocida del triangular y redentorista 153 (ó 17x9), advertir la reaparición del modulus de 17 en destacados textos (el sonetto CXVIII p.e.), marcados posicionalmente, o en estructuras secuenciales parciales, narrativas y/o temporales, integradas en el sistema. 
Sobre todo cuando, tras reconocerlo en fragmentos varios, secuencias imbricadas o secciones significadas (con frecuencia solapadas, no exactamente sucesivas), verificamos ahora de nuevo el 153 como total, resultado definitivo de una dispositio alternativa -la propuesta por las numeraciones marginales del Vat. lat. 3195- y total referido, de forma que considero medida e intencional, una vez más, a las fechaciones inicial y final de la aventura narrada como transformazione. Es la summa biográfica pertinente $a b$ initio, desde la data sacra del CCXI hasta el sonetto CCCLXIV davidico $e$ penitenziale (Chessa 2005: 296) del último aniversario y la última revisión cronológica de esos 31 años. Santagata ed. 2004: 1406 ss.; Bettarini ed. 2005: 1603 ss; Tonelli 2007: 813-815; Armisén 2011: 33 ss. Lo he tratado con más espacio al comentar el caso de Sannazaro y el anclaje cifrado de sus Sonetti et canzoni (Napoli, 1530) con la mencionada puerta de entrada al «laberinto» en el famoso sonetto CCXI. Armisén 2014/2015.

Recordemos, pues, lo ya dicho. Advirtamos de nuevo, siquiera para los que desconocen (o, mejor, evitan y omiten) los trabajos de Pötters, que desde el inicio del año 17, marcado por el sonetto de aniversario CXVIII de Petrarca en el que se presiente de nuevo la muerte de Laura -texto y año que tanto interesaron después a Sannazaro en su último sonetto 98 «O mondo, o sperar mio caduco e frale», el número de fragmenta que, incluido el sonetto de esa fechación, conforman los restantes $R v f$ es de $249^{15}$.

Hemos de tener muy presente lo que he señalado en otros trabajos sobre la secuencia particular CXVIII - CCLXX/CCLXXI en cuanto forma narrativa cifrada por el 153/154 que establece y marca numéricamente, quizá por vez primera tras el sonetto IV, el sentido espiritual de su relación con Laura y la influencia divina en la misma.

No olvidemos, por tanto, con las opiniones de la crítica anterior sobre el año 40 de Petrarca, las observaciones aritméticas de Pötters sobre el 7, el 10, el 17 y el año 17 (1984: 172; y 1987: 63 ss.), ni tampoco la ya mencionada numeración de los dos grabados sobre la pesca milagrosa de Wiericx/Nadal en 1593. Las coincidencias numéricas con las cifras y posiciones que estudio en los $R v f$ nos interesan. Como digo, por lo menos prueban la pervivencia activa del código numérico en los siglos XVI y XVII. Han de ayudarnos también con el reconocimiento y verificación de sus antecedentes y otras posibles secuelas.

Como Baldassarri señala en fecha reciente, el sonetto CXVIII «Rimansi a dietro il sestodecimo anno», incluye una mención inicial de Fortuna (v. 7) asociada en cuanto timore a sus tempranas preocupaciones sobre la hipotética muerte de Laura (2004: 30 y 32). La importancia del tema, que se

\footnotetext{
${ }^{15} \mathrm{El}$ interés del 17 como cifra simbólica de la Gratia (Agustín, In Iohannis...) que marca repetidamente, por lo menos, un punto de partida en los $R v f$ ayuda a valorar, quizá, la plural lectura del v. 17 «et maledico il dì ch'i' vidi '1 sole» de XXII, primera de las 9 sestine del libro, texto relacionado probablemente con la edad de Petrarca en el primer encuentro fechado el 6-IV-1327 (Santagata ed. 2004: 91; Bettarini ed. 2005: 96 ss. y 99, nota v. 17); ...y también el sonetto XVII que, tras el sonetto XVI del peregrino «vechierel canuto e bianco», tal vez, con el apoyo de una reconocible cifra numérica constata (o señala) el inicio de su viaje espiritual. Armisen 2013: 218. Sobre el año 17 en el canzoniere de Sannazaro véase A. Armisén 2014/2015: pend. de publ.
} 
convierte en dominante en la macrosecuencia iniciada ahí, aconseja ahora recordar lo que se ha dicho acerca de la sustitución ideológica en los $R v f$ de Fortuna por Amore, Laura y Morte.

Recordemos también la centrada alusión a Providencia de Boscán en el soneto LXXVII [49], vv. 3-4 de 1543 «no es fortuna quien manda ya esta rueda:/ más alto’stá mi mal o mi remedio». Es el primero de los cuatro sonetos centrales del Libro II sobre la creación de su dama. Armisén 1982: 391 394; y 2004a: 89. Pensar que Boscán podía ver y leer, en alguna medida de precisión difícil, la huella de Providencia en el caso de Laura resulta obvio, es consecuente. Y no puedo pensar que fuese el único en alcanzar esa lectura. Al menos, el barcelonés lo considera tema adecuado para textos cardinales que, más allá de la simple sucesión biográfica y temporal, ocupan posiciones fundamentales en la composición petrarquista y agustiniana de su canzoniere castellano.

Que lectores modernos desconozcan y nieguen (o no sepan reconocer en el siglo XXI) las formas de espiritualidad del Libro II señaladas y comentadas ya en 1983, aparte cuestiones referidas a la calidad poética de Boscán, obedece a otras causas y razones muy distintas en las que no me extenderé. En cualquier caso, la práctica de citar bibliografía que no se ha trabajado es cuestionable en sí, y peligrosa en la interpretación filológica. Sin lugar a dudas, el mérito de la tosca poesía de Boscán es muy inferior a su interés histórico literario. Su escritura muy pocas veces alcanza una imitación válida del modelo italiano, pero negar su componente espiritual es ignorar el texto de 1543 y supone también desconocer su forma numérica. El petrarquismo del barcelonés mejora cuando imita, reescribe y evoca con emoción la poesía castellana de Garcilaso.

En los $R v f$, la composición de esa macrosecuencia de 249 unidades y su ratio permitirán entender mejor las razones de esa sostituzione y las implicaciones formales de la que desde 2004 denomino data tragica (CCCXXXVI, vv. 12-14). La importante macrosecuencia central, simétrica, de las enfermedades y muerte de Laura (XXXI-CCCXXXVI) de 306 unidades(Armisén 2008a: 50-51) se potencia desde el año 17 de la pasión de Francesco y tras el sonetto CXVIII con la localización de la razón proporcional que en los últimos 249 pezzi guarda una clave espiritual de los $R v f$. En relación con el problema que la ratio resuelve, la afirmación que cierra el sonetto CXVIII parece el reconocimiento de la incapacidad del poeta para resolver por sí solo el conflicto en que se debate. La unidad del Canzoniere, sostenida por la imbricación de macrosecuencias posicionales, integra textos particulares e interdependientes, con lectura plural o relevante en más de una de ellas. Creo inconveniente detenernos ahora en la ejemplificación y análisis de ese problema.

Encontramos aquí, como clave de la macrosecuencia CXVIII-CCCLXVI de 249 pezzi, la presencia decisiva de Providencia, antes adelantada, señalada en cuanto poder mencionado en el sonetto IV que, con el tema del nacimiento de Laura, cerró la primera página del codice con la introducción textual de su condición funcional figurada. Armisén 2004a: 83-84, 89 et al.; 2008a: 49, 51, 58 et al. Repasaremos datos conocidos y otros textos que pueden ayudarnos en la lectura, reconocimiento formal e interpretación de los $R v f$. 
Con el apoyo de la lectura parcial esbozada por Anton Maria Amadi en 1563, el sonetto IV es texto posicional y temáticamente destacado en relación con la armonía (también «armonia dell'eloquenza», sic. H. Wayne Storey 2004: 132), reconocida ahí por lectores del Cinquecento con acceso confirmado al «codice de autor» que conocemos hoy como Vat. lat. 3195. Un sonetto que $(1+2+3+4)$ cierra el fol. 1 recto con 56 vv. (Armisén 2008a: 48-49, 58 et al.), marcando y emplazando el figurado simbolismo piscatorio y redentorista del libro. Providencia divina se ofrece como activo componente agustiniano, integrado con intención desde la página inicial. El propio Vellutello reconocía la sostenida atención de Petrarca a su influencia en la creación de Laura (vid. sonetti IV y CCCLII, «antes» 363 en el codice autorizado; ed. 1538: 5 recto y 132 verso)

Recordaré algo que ya sabemos: 249 y 154 son cifras y medidas relacionadas entre sí, con aproximación perceptible (aunque no coincidencia exacta desde las milésimas: 1'616883...) a la proporción que conocemos como sección áurea (o «de la media y extrema razón»: 1'6180339...). Una ratio atribuida a Pitágoras que tiene huella reconocida en los Elementos de Euclides ${ }^{16}$. Con el antecedente de la numerología cristiana propuesta por Agustín, la razón será cristianizada, comentada explícita y tardíamente como divina proportione por fra Luca Pacioli (Venecia, 1509) ${ }^{17}$. El comentario del matemático franciscano sobre sus doce propiedades (que son trece [ó 12+1] ..., caps. XXII y XXIII de Pacioli ed. 1991: 58-60.) permite verificar todavía la adecuación del duodenario cristiano más conocido con la forma+1; o la presencia coincidente y tardía de la ratio -ajustada, supongo, en el proyecto de autor- con la conocida cifra apostólica y la redención. Armisén 2011: 14-17 y nn. 6 y ss.

Si aquí tomamos en consideración las implicaciones simbólicas del análisis de Agustín sobre el 153 y el 154 de la pesca evangélica, el interés de la presencia de la sesquitertia ratio y el de la conocida media y extrema razón -que entiendo construida con esas mismas cifras en la obra de Petrarca- crece y se potencia. Recordar la mención de Pedro y Juan, presentados como precedentes funcionales, instrumentos de la Redención o figurae de Laura en el sonetto IV, se hace de nuevo oportuno. Siglos después, la presencia repetida del tema de la pesca milagrosa entre los motivos evangélicos que, destacados en el programa iconográfico de la Compañía de Jesús, alcanzan representación pictórica codificada suscita atención crítica ${ }^{18}$.

\footnotetext{
${ }^{16}$ Vid. Euclides, Elementos ed. 1991-1996: además de una definición en lib. VI, 29-30, véase la indirecta referencia del lib. II; o su aplicación en la construcción del pentágono, lib. IV; y en relación con el icosaedro y octaedro, lib. XIII] cif. M. Livio 2006: en particular 89 y 87-94.

${ }^{17}$ En un estudio hoy clásico, Erwin Panofsky advertía sobre «el prestigio insólito» y «la exagerada valoración» de la sección áurea en el Renacimiento que llevó a relacionar esta proporción con diversas divinidades ([1955] ed. 2006: 103 ss. y 126). En 1955 su opinión se fundaba muy especialmente en De divina proportione de Luca Pacioli, texto que citaba breve y generalmente por la edición de Viena, 1899; y en el De Harmonia mundi totius cantica tria ([1525] Paris, 1545) de Francesco Giorgio (1460-1540). C. Butler 1970: 56 ss. dedica alguna atención a Giorgio, pero descuida o ignora y no comenta el caso de Pacioli.

${ }^{18}$ En vida de Petrarca la pesca milagrosa, en cuanto último milagro (contrástese Lucas V, 1-11 y Juan XXI, 1-25) era tema destacado del Evangelio de Juan; y, junto a otras exégesis del caso, mereció atención detenida en la Vita Christi, summa evangelica del cartujo Ludolfo de Sajonia. En fecha anterior ambos milagros, codificados y contrastados por Agustín, interesaron a Duccio Buoninsegna (1255-1318 ó 1319) en sus trabajos para el retablo de la Maestà (1308-1311). La Aparición del lago Tiberíades, pintura al temple sobre madera fue realizada, como parte de la sección post mortem, para la Maestà en Siena (hoy en el Museo dell Opera del Duomo). No faltan otras realizaciones sobre el tema que destacan sobre las brasas el simbólico pez aportado por el propio Jesús: sic. «Tercera aparición de Cristo», anónimo after Dirk Bouts
} 
Estos números cifran la Redención, tanto por referencia a los 153 grandes peces extraidos en la red, como por la suma con el pez que Jesús Resucitado trajo consigo (153+1): «Piscis assus. Christus est passus. Ipse est et pannis qui de caelo descendit.» Según he advertido en 2004b: 66, Agustín en su exégesis no deja lugar a muchas dudas sobre la adecuación y sentido del número evangélico, ni sobre el significado del pez que Jesús aporta y con el que inician la comida. In Iohannis evang., 123, 2. A finales del siglo XVI, la atención cuidadosa con que el autor/ordenador/comentarista y el grabador (Jerónimo Nadal / Hieronimus Wiericx, Antwerp, 1593) tratan el tema en el grabado CXVIII de las Imagines sólo nos lo confirma.

Muchos años antes, reconocer la presencia repetida de la forma +1 en el De divina proportione de fra Luca Pacioli permite verificar en 1509 que se trata de un uso numérico y cristiano que no es excepcional, ni queda limitado al milagro de Tiberíades. El interés de la obra del franciscano y sus antecedentes se hace evidente por muchas razones ${ }^{19}$. El número que cifra in ordine el grabado concebido, compuesto y ordenado por Nadal, realizado como plancha por Wiericx, puede merecer atención por su significada presencia anterior en los $R v f$ y en los Psalmos. No son datos aislados, aunque la ordenación de las Imagines, realizada antes de 1580 por Nadal, ejemplifica casos y grabados muy tardíos cuando intentamos explicar las posiciones, causas y razones de los Rvf.

Estudiamos cifras simbólicas de largo recorrido, con precedentes y aplicaciones que semejan pertinentes por su presencia frecuente, anterior y posterior, en textos y espacios relevantes. Será útil recordar que el pez alcanzó en la tradición cristiana anterior la condición de símbolo de Jesús Redentor; y también que el 153 era, por lo menos desde Arquímedes (n. ca. 287 a. de C. / m. ca. 212 a. de C.), número conocido, utilizado antes de la difusión de los números irracionales en la representación muy aproximada de la raiz cuadrada de tres: 1'73205080...[ $\sqrt{3} \approx 265: 153=1$ '7320261...]. El nexo simbólico o la interrelación ocasional y presumible de esos datos provocan creciente interés.

Era, es una famosa proporción y la casi exacta representación abreviada de la $\sqrt{ } 3$, aplicada tempranamente y reconocida en la historia de la aritmética. Tiene una primera aplicación conocida ( $\sin$ explicaciones...) en Medición del círculo (Arquímedes ed. 2005: prop. 3; vid. introd. 241, y 247-249)

\footnotetext{
(1410-1475), quizá de inicios del s. XVI. Sobre ambos milagros y los tres grabados incluídos en las Evangelicae Historiae Imagines del P. Jerónimo Nadal, S.J. (Cristobal Plantin, Antwerp, 1593), cifrada con los 153 numerados (+ 1 de portada) obra de los hermanos Jerome y Anton Wiericx, Bernardino Passeri y Marten de Vos, he tratado en Armisén $2004 \mathrm{~b}$ : 71 ss. y $99-100$.

${ }^{19}$ Pensemos en el comentario de Pacioli sobre las doce propiedades de la divina proportione (que son trece) que explica con el antecedente sagrado de los participantes representados en la Última cena, mural de Leonardo realizado para Ludovico Sforza en Santa Maria delle Grazie, Milano. Vid. Pacioli [1509] ed. cast. 1991: cap. XXIII, 59-60. En el capítulo V del De Divina Proportione ([1509] 1991: 41-42) Pacioli, que también dedica su obra al Duque, justificó su título con cuatro razones (que son cinco) referidas a epítetos divinos. Sostiene la semejanza de la aurea ratio por su unicidad, «supremo epíteto de Dios mismo»; por su definición en tres segmentos y la Santísima Trinidad; por la inconmensurabilidad del número áureo y la imposibilidad de definir a Dios; por la autosimilaridad y la omnipresencia de Dios «en todo y por todo»; finalmente la quinta correspondencia la establece Pacioli: «así como Dios confiere el Ser a la virtud celeste, por otro nombre llamada quintaesencia, y a través de ella [...], de igual modo nuestra santa proporción confiere el ser formal ... [sic. Platón, Timeo] al cielo mismo, atribuyendole la figura del cuerpo llamado dodecaedro [...] el cual [...] no puede formarse sin nuestra proporción». La condición fundamental (y modular) del dodecaedro en cuanto quintaesencia del Universo y su relación con la divina proportione merece ahora toda nuestra atención. Armisén 2011: 15 y n. 9.
} 
y presencia posterior integrada (en relación con el triángulo equilátero e implicaciones trinitarias) en el símbolo paleocristiano vesica piscis. Lo forman dos circunferencias con el mismo radio y exactamente solapadas, de modo que el centro de cada círculo está en la circunferencia del otro. Sus centros distan ese mismo radio compartido. El citado símbolo, la yuxtaposición de ambos círculos formaliza, en ocasiones, el fundamento geométrico y aritmético original de la críptica mandorla de la escultura, pintura y arquitectura religiosas.

Como la exacta mandorla geométrica descrita integra dos triángulos equiláteros contrapuestos que comparten uno de sus lados, sus dos ejes (mayor y menor) se ajustan a la $\sqrt{3}$, ratio que antes de la difusión de los números irracionales se representó y aplicó en la casi exacta proporción 265:153. Para alcanzar una mayor precisión era necesario trabajar con cifras mucho más elevadas. Una proporción conocida, que ocupa lugar reconocido en la historia de la aritmética y ahora nos ayudará a entender mejor el diseño de la Piazza di San Pietro, obra de Bernini.

En esa proporción o ratio abreviada, operativa en el vesica piscis y cifrada por la $\sqrt{3}$, el $265 \mathrm{se}$ refería o representa el eje mayor, la altura de la mandorla, la distancia que separa las intersecciones de las circunferencias. Probablemente pitagórico, el número triangular 153 corresponde en la ratio al eje menor, lado del mencionado triángulo equilatero, coincidente con el radio de esos círculos y distancia que separa sus centros. Son formas que cuentan también con conocidos, perceptibles antecedentes en Euclides: hablo de la «Proposición I. Construir un triángulo equilátero en una recta definida dada» (Elementos, Libr. I, 1; ed. 1991-1996, vol. I: 201-202). Armisén 2011: 24 y n. 16. Si hemos de tener presente la condición triangular de la cifra evangélica interpretada por Agustín tampoco debemos olvidar la Proposición I, 1 de Euclides. Y Pacioli en 1509 viene después a confirmar con su exégesis la adecuación de la sección áurea o el implícito interés trinitario del problema. Supra n. 19. El diseño de Bernini no carece de antecedentes.

Tanto si las formas icónicas religiosas medievales que comento (vesica piscis y mandorla) eran precedentes inmediatos y bien conocidos en sus implicaciones aritméticas por Petrarca -en muchas ocasiones las mandorlas románicas y góticas parecen poco o nada ajustadas en sus exactas medidas; ajenas a la conciencia e intención de canteros o artesanos menores que, con rigor y precisión geométrica variables, repetidamente las trabajaban- ...como si el poeta toscano tampoco valoraba esos precedentes en lo referido a sus implicaciones aritméticas y/o geométricas, será conveniente tenerlos hoy muy en cuenta. Documentan la huella operativa, el interés anterior y duradero del 153, la cifra numérica que nos interesa más, en formas próximas y espacios sagrados relevantes. Su presencia resulta significativa y precisa en algunos casos. El número de las esculturas que coronan la Piazza, aunque generalmente descuidado por los estudiosos, nos lo confirma en esta ocasión.

La peregrinatio a Roma prueba, siglos después de 1374, la pervivencia funcional de la cifra y las formas que nos interesan. Y aunque, como sabemos desde 2004, no falta evidencia visual perceptible y cuantificable de su calculada presencia en el Vaticano $(1+12+140$; número de las esculturas, difícil de verificar visual y directamente in situ... Armisén 2004b: 82-98), su intencion simbólica se afirma con el diseño espacial unitario de las 153 tallas, pero subyace implícita y se 
confirma silenciosa solo a quien, conocedor de la cifra evangélica y sus antecedentes, la intuye necesaria o la convierte en objeto de búsqueda. Ha sido ignorada y desatendida por estudiosos de ese espacio durante siglos.

Si es cifra evangélica directamente accesible (con alguna dificultad, como digo) en lo referido a las 153 figuras ejemplares de la cristiandad, semeja críptica en el diseño geométrico y aritmético de la Plaza. Con su llegada a la famosa platea Sancti Petri, los fieles, peregrinos y visitantes se unen en un espacio consagrado de la memoria colectiva, atrio de recepción y reunión jubilar.

No debe ignorarse la presencia coincidente del 153 , suma total de las 13 esculturas sobre la fachada del templo Vaticano y las 140 del colonnato de la Piazza di San Pietro, con la huella cifrada (vesica piscis y mandorla incluidas) en la planta de la misma Piazza, vestibolo Vaticano según el diseño de Gian Lorenzo Bernini (Armisén 2004b: 101 [sic. plano de F. Borsi, 1980: 88 y portada], et $a l)$.

Estamos ante un ejemplo presumible de significativa aplicación del vesica piscis que -aunque silenciada e ignorada...-- podía ser reconocible siquiera para los iconógrafos, geómetras y aritmólogos cristianos interesados en la planta del proyecto; pero también encontramos, obvia, perceptible y verificable ahora en el plano descriptivo de Borsi, la mandorla umbral, con la invisible cruz de sus dos ejes (recordemos $\sqrt{3} \approx 265: 153$ ), símbolo sagrado de recepción en ese Theatrum mundi, centrados ambos y dominados por el antes reubicado obelisco (Curcio 2003: CLXX ss.), culminado así mismo por la cruz visible. Armisén 2004b: 89-90. Si el plano de Borsi, que él no interpreta en los detalles cifrados que ahora nos interesan (1980: 88-91), da cuenta con alguna exactitud de la realización del espacio que reproduce, la intencionalidad del proyecto de Bernini en la aplicación con la mandorla de la $\sqrt{ } 3$ y el 153 evangélico se hace evidente, me parece ya incuestionable.

El discutido obelisco se asienta hoy en la línea que une los dos centros de círculo en el «ovato» (vesica piscis) de la Piazza ( $\mathrm{F}^{1}$ y F $\mathrm{F}^{2}$, en Borsi, p. 90), en la cruz y centro de ese segmento central, radio compartido de ambos círculos y también lado del triangulo equilátero (sic. Euclides, Proposición I, 1, vid. Borsi, p. 88). Ocupa el punto axial y central de los dos ejes de la sagrada y velada mandorla implícita, sobre el eje menor que establece el simbólico triángulo, representado en la proporción que cifra la $\sqrt{3}$ de los ejes en esa forma umbral, con el triangular, pitagórico y evangélico 153. Vid. Borsi 1980: 87-90; y/o la accesible reproducción del plano mencionado en Armisén 2004b: 101.

La contradicción que Borsi señalaba entre la bifocalidad del ovato tondo, visual, confusamente descentrado por las dos fuentes, y el famoso obelisco que considera devaluado ( $«$ messo tra parentessi, psicologicamente "rimosso"», Borsi 1980: 87 y 96) creo que se resuelve y entiende mejor si reconocemos y valoramos la integración funcional de la mandorla en el vesica piscis paleocristiano y apreciamos con ellos, con la $\sqrt{ } 3$ y la cifrada ratio de sus ejes (265:153), la presencia triangular de la Santísima Trinidad.

La lectura cristiana, aritmética y geométrica con el 153 evangélico de las figuras ejemplares y su presencia críptica en el triángulo equilatero, símbolo trinitario implícito, se impone al estudioso del espacio sagrado. El número solidario de las estatuas de la Iglesia Triunfante que rodea la plaza y abraza 
a fieles y peregrinos, como advertí, parece determinante en la significativa composición del regista del Barocco y en su reconocimiento. Armisén 2004b: 85 y n. 24. La presencia de las fuentes en la plaza obedece, quizá, a otros intereses. En mi opinión actual, impresiona como resultado de un compromiso con la aspiración a obtener otras metas estéticas; pero solo retrasa u oculta en principio la forma esencial subyacente. El plano de Borsi, que reproduje en la última página del trabajo de 2004, me parece ahora evidencia más que suficiente.

El diseño berniniano queda formalizado con el solapamiento medido de las dos circunferencias, círculos y mandorla unificados con el «153» del radio compartido. Simboliza e integra el conocido triángulo equilátero trinitario de la iconografía cristiana, sostenido por la geometría de los cuatro triangulos rectángulos. Sus hipotenusas quedan cifradas también por el 153, número integrado en la ratio de los ejes cruzados y en los equiláteros contrapuestos de la sagrada mandorla umbral. Con las propuestas e implicaciones del teorema de Pitágoras (Elementos, I, prop. 47; ed. 1991: 260-262 y 6667), no perdamos tampoco de vista la primera Proposición de los Elementos de Euclides.

La histórica $\sqrt{3}(\approx 265: 153)$ establece en la exacta mandorla, como razón cifrada de sus dos ejes, la relación simbólica y la distancia de ambos círculos (un operativo y simbólico «153», paleocristiano «numero del pez»), abrazados por el colonnato y dominado todo por las 153 figuras ejemplares que reciben a los peregrinos. Bernini actualiza, en mi opinión, una aplicación plural, coincidente, trabajada y significativa de la cifra evangélica (triangular de 17) que estudio ahora en el espacio del reencuentro final. Como radio compartido y eje menor de la mandorla, con su presencia histórica en la forma breve de la $\sqrt{ } 3$, genera, mide y cifra el perfecto triángulo equilátero. Reconocer así el interés del número de estatuas señalado en 2004 para la percepción inicial, lectura y comprensión de este espacio de la memoria es ahora fácil.

Y, como advertí en esa fecha, aunque la nueva maravilla romana de la cristiandad suponía la culminación de un programa anterior con modificaciones diversas, marcado quizá por el traslado e instalación definitiva del obelisco egipcio (1586), será útil saber más sobre la ulterior relación del P. Athanasius Kircher, S.J. con la realización del proyecto final de Bernini. Dado el valor funcional de la $\sqrt{ } 3$ (y de $\pi$ ) en estudios sobre el círculo y la circunferencia; o sobre el hexágono, pentágono, cuadrado, rectángulo, triángulo, etc. podrían ser pertinentes, parecen datos útiles y necesarios en la lectura espacial, geométrica y simbólica del mencionado proyecto. Armisén 2004b: 90 ss. y n. 28, con reproducción reducida del mencionado plano de Borsi en la p. 101.

Trabajamos formas y números reconocibles para conocedores de la numerología de Agustín, aunque no limitados por ella. Porque el valor documentado de la cifra y alguna de las aplicaciones del 153 preceden, según señalé en otros trabajos, a su conocida huella en los Evangelios ${ }^{20}$. Pero su

\footnotetext{
${ }^{20}$ La cifra de la pesca milagrosa de Tiberíades ha interesado también en la cultura hebráica y pudo tener presencia operativa en Templo. Véase lo que dice sobre el censo de Salomón y los 153. 600 «extranjeros» que trabajaron en la construcción del templo de Jerusalén Michel Remaud, Vangelo e tradizione rabbinica, Bologna, EDB, 2005, p. 131, n. 34. No parece fácil encontrar una explicación sencilla y aceptable. La cristianización evangélica del 153/154, antes de su integración en el Vaticano y la Piazza di San Pietro con el diseño de Bernini (Armisén 2004b; y 2011: 20 y nn. 13 y 16), era muy conocida en círculos religiosos. Junto a los trabajos de miembros destacados de la Compañia de Jesus que he comentado, la he
} 
aplicación posterior en la codificación simbólica cristiana se confirma también como bastante anterior a Agustín. Armisén 2011: 20 et al. y n. 13. Si el número de los apóstoles era doce y el de los discípulos 72 -como el de las naciones y lenguas en tiempos de Noé (sic. De civitate Dei, XVI, 9)-, en algún momento de la inicial y creciente iglesia de Cristo el total de sus obispos parece haber sido 153. Fácil es verificarlo con ayuda de la Patrologia latina de Migne atendiendo ahí a la documentada presencia del evangélico y redentorista centum quinquaginta tria.

\section{Sobre numeri aeterni y las aportaciones de W. Pötters. Un dramma di numeri e di proporzioni} (Bettarini, 2005). El lector inscrito y la lectura actual de los $R v f$. Preámbulo formal y aurea ratio. La lectura espiritual del codice: el 153/154 y el sonetto CCLXXI.

Aunque Wilhelm Pötters en sus conocidos estudios sobre el Canzoniere permanece ajeno al texto evangélico, a la exégesis de Agustín y al sentido religioso o espiritual de estas cifras, algu na de sus elaboradas observaciones numéricas resulta particularmente sugerente. Sus trabajos, silenciados y no sé si entendidos en lo relativo a sus propuestas más útiles, pero rigurosamente eludidos en estudios y ediciones importantes e inexcusables, ofrecen aportaciones valiosas que ahora no cabe ignorar.

En 1984 y 1987, con la relación aritmética proporcional en los $R v f$ del 249 y el 154 -número éste que el profesor alemán reconoce y valora en cuanto componente total silábico del sonetto italiano-, ponía ante nosotros una evidencia formal relevante que los críticos atentos a la composición de las rime sparse o siquiera interesados en anotar y comentar los sonetti CXVIII, CCLXXI desconocen, han descuidado o prefieren ignorar. Su trabajo de 1998 recuerda después la atención que el problema de la aurea ratio tuvo en la cultura aritmética y geométrica de la edad media, pero apunta a una relación entre cifras localizadas en la forma sonetto y en los $R v f$ que no deberíamos desatender ${ }^{21}$. Conocer la difusión de la exégesis numérica de Agustín o su repetida aplicación en la obra de Petrarca permitirá alcanzar una comprensión avanzada y coherente, la interpretación documentada; en destacadas ocasiones, incluso proponer una lectura histórica, rigurosa y verificable.

Son datos útiles los que encuentro en el especulativo trabajo sobre la relación posible de la forma sonetto y sus 154 sílabas con el triángulo rectángulo: Pitágoras...Paolo dell'Abaco [1271-1374] (Pötters 1998: 104-110; fig. CXV, 165 et al.), ampliadas en 2007: 281-286 et pass. Las medidas regulares y conocidas proporciones del grupo estrófico son puestas en hipotética relación o siquiera contrastadas por Pötters con estudios anteriores sobre la cuadratura del círculo (Franco de Liegi [1050 ca.] cif. Pötters 1998: 62 et al.) o con información sobre la sección áurea de los segmentos del pentagrama inscrito en el famoso pentágono pitagórico (Pötters 1998: 111 ss; Euclides, Elementos, (lib. IV, pro. 11) ed. 1991: 355 ss. y n. 99; vid. Livio 2006: 42-45). La posible o probable relación de

localizado también en ámbitos herméticos y numerológicos del siglo XVI interesados en la obra de Petrarca. Pienso ahora en el caso particular de Anton Francesco Doni (1513-1574). Armisén 2004b: 82, n. 21.

${ }^{21}$ Vid. Pötters 1998: 104 ss. et al. El 154 (total de sílabas de la forma sonetto en los trabajos del profesor de Würzburg) y el 249, número de textos de los Rvf desde el sonetto CXVIII que data el año 17, como números recíprocos han sido asociados por el estudioso alemán con la aurea ratio que hoy conocemos como divina proportione [154:249 = 0'61847... ó parte aurea dell'unità; sic. Pötters 1998: 106 [0’6185...]; y con el número áureo 249:154 = 1’6168...; sic. Pötters 1998:110 [1'6180...] 
la forma sonetto y su génesis con la matemática y con la geometría estudiadas en la corte de Federico II ayudan ahora directa e indirectamente en la recuperación de la composición de los Rerum vulgarium fragmenta y en su interpretación.

No perdamos de vista tampoco que el digno de admiración y dignísimo decimotercer efecto de la divina proportione, según Pacioli, op. cit. cap. XXII ([1509] 1991: 58) se refiere al pentágono y al dodecaedro (el mas noble entre todos los cuerpos regulares), cuerpo de doce bases pentagonales «cuya forma atribuye el divino Platón a la quintaesencia, es decir al cielo con razones muy convenientes» (figs. XXVII y XXVIII de Leonardo).

Por otra parte, como sabemos, 72 [ó 12x6] es el total de folios numerados del codice autorizado que estudiamos, con huellas de dos manos en esos mismos números. Zamponi 2004: 13-15; contrástese con Savoca 2008b: 3 ss. Vid. Armisén 2008a: 60-61 y n. 9. Si la forma unitaria y modular del sonetto tuvo en sus orígenes fundamento matemático, como propone Pötters, no faltaban antecedentes formales a los canzonieri en la numerología cristiana o en la geometría platónica fundamental. Evaluar la reiterada presencia del 153/154 no será inútil. La huella del 6 el 12 y el 72 en las sestine y en las formas del codice y texto literario de los $R v f$ merece así mismo alguna atención. Conocer también que 72 era número con huella en los Evangelios, integración supuesta en el Panteón (sic. Pacioli, 1509) o significada presencia (hoy considerada espúrea, pero impresa en 1482 y considerada correcta durante siglos: del XIII hasta el XVIII ó XIX) en los manuscritos latinos, traducciones y ediciones de los Elementos de Euclides parecen datos pertinentes. Según he advertido cumplidamente, el De divina proportione (Venezia, 1509) de fra Luca Pacioli y su traducción de los Elementos, publicada en esas mismas fechas, documentan tardíamente su reconocido interés anterior. Armisén: 2011: 14-16, nn. 616 et al.

Centrémonos en los $R v f$ y volvamos al tema que nos ocupa. Incluso sin ir aquí más allá de una breve y tentativa lectura, puede valorarse la composición de esa macrosecuencia o sección de 249 pezzi iniciada con el sonetto CXVIII que señala el año 17. Tras las observaciones iniciales (Pötters 1984 y 1987: 63 ss., 51, et al.; Armisén 2004a: 93-94) el problema simbólico y su huella formal integrada en la composición nos interesan. Armisén 2008a: 59-60, n. 8; 2011: 12 et al.; y 2013: 203 ss.

Porque no se trata en este caso siquiera de estructura única o exclusiva, ni tampoco de una observación aislada. Junto a la reiterada presencia de la numerología de Agustín, podemos constatar que otras secuencias imbricadas -integradas, simplemente superpuestas o parcialmente solapadasparecen apoyarse en el mismo sistema de los aniversarios (en esta ocasión, sobre los 12 textos CVIICXVIII, referidos al inmediato año 1342-1343: palcoscenico construito all'interno del Canzoniere, sic. McMenamin 2001: 6 y 8) y lo sostienen con la sucesión de peticiones en el umbral de la macrosecuencia de 249 últimos fragmenta.

Entiendo así que la secuencia previa inmediata, relacionada con el año 16, revisada recientemente por McMenamin (CVII-CXVIII) constituye un preámbulo formal, cronológico y operativo de 12 pezzi que, en el marco del tema de la amicitia: amistad / amor / caritas (Agustin, De 
civitate Dei...; Tomás de Aquino, Summa, IIa, IIae, 23. a. 1, resp.; y Bettarini 2005: 1614), sitúa a Sennuccio del Bene como interlocutor preferente destacado en los sonetti CXII y CXIII (Barber 1982: 21 ss, 31; Picone 2007b: 281-286). Realza y señala desde el año 16 de lunga guerra amorosa (CVII, v. 2) en que el poeta no sabe cómo podrá salvarse, retenido por las ramas del laurel, arma de Amor (vv. 12-14), el paso al decisivo año 17 (CXVIII, v. 1). Y ese preámbulo o atrium de 12 componentes -recordemos su condición de número pluscuamperfecto, sic. Agustín (Armisén 2012: 87)- se cierra en/con el inicio de la macrosecuencia que estudio ahora. Habrá que volver sobre el símbolo arbóreo de Laura tantas veces comentado.

Con las conocidas propuestas de Pötters (1987: 35 ss.; 1998: 21-125) sobre las proporciones de la forma (repetida, modular y dominante en los Rvf) del sonetto italiano de 154 sílabas que, unidas en 1998 a su revisión de la matemática de esos siglos, tienen interés en sí mismas, reconocemos mejor la forma narrativa compleja de los $R v f$ construída repetidamente con el 17 y sus múltiplos, con el sentido espiritual del 153/154 redentorista y el pensamiento de Agustín ${ }^{22}$. No olvidemos tampoco el caso del sonetto CCXIII, cifrado simbólicamente mediante sus dos últimas sílabas (153/154), con lectura sostenida por su posición en el texto literario de 366 pezzi $(60+306$ [ó 153+153]) y en los 72 fogli numerados (v. 56 del fol. 42, recto) del codice autorizado...Armisén 2008a: 63 ss. Vid. infra.

En la macrosecuencia de 249 pezzi (CXVIII-CCCLXVI), la coincidencia solo muy aproximada de la cifra evangélica del 153 con la proporción áurea en la canzone CCLXX o la más exacta del 153+1 (recordemos: componente o factor numérico evangélico y agustiniano) con la conclusión del sonetto CCLXXI (fol. 56 recto) del año 21 de la muerte de Laura -año evocado, mencionado después con intención en el texto que concluye la secuencia biográfica CCXI-CCCLXIV de 153 pezzi-, marca y cifra la composición. Parece decisiva en la lectura formal del macrotexto. Arroja nueva luz sobre la presencia emergente de Providencia en los $R v f$.

El proceso textual y espiritual reiniciado desde el año 17 y el sonetto CXVIII, cronológicamente, se cierra «pentito et tristo de' miei sì spessi anni» en 1358 (sonetto CCCLXIV, que cierra y resume la

\footnotetext{
${ }^{22}$ Sería simplificación errónea limitar el interés de la cifra $153+1$ a la exégesis de Agustín, dado que la forma+1 tiene presencia repetida en otras cifras, en enumeraciones y representaciones varias. Armisen 2011: 24 y n. 17. Pero es fácil verificar anterior y silenciosa atención a la misma en una tradición pictórica relacionada con la materia que en algún otro caso, quizá, pudo conocer el propio Petrarca. Supra n. 18. El interés simbólico del pez que Jesús resucitado lleva consigo se confirma repetidamente como motivo codificado de la representación y exégesis del milagro piscatorio, integrado en comentarios evangélicos y formas plásticas narrativas sobre la vita Christi. Pienso ahora tanto en la tradición anterior, que ejemplifica el anónimo, próximo a Dirk Bouts, de la escuela holandesa de inicios del siglo XVI, como después en los tres grabados de Nadal/Wiericx que tratan el tema en los 153 grabados +1 de portada de las Evangelicae Historiae Imagines (Antwerp, 1593), texto fundamental en el programa iconográfico de la Compañía, vid. Armisén 2004b: 72-81 y 99-100); o también en las dos grandes pinturas del presbiterio sobre La pesca milagrosa (Lucas, V) y La aparición de Cristo del lago Tiberíades (Juan, XXI), junto al altar mayor en la Catedral de san Pedro de Jaca, y en sus transportables bocetos (17911792; Museo Diocesano), obra del cartujo fray Manuel Bayeu Subías. La primera, con modificación del boceto inicial, corrige y reduce finalmente el detalle de las barcas sobrecargadas por la pesca, interpretado por Agustín como figuración de cismas y otros problemas futuros de la Iglesia. Y «La aparición....» se refiere al milagro final del Evangelio de Juan con Jesús en la orilla y su pez ya en las brasas antes del desembarco, los 153 grandes peces todavía en las redes... El interés simbólico del pez de Cristo había sido reconocido por Agustín en su conocido comentario, texto asumido, revisado y difundido por la Vita Christi de Ludolfo de Sajonia, et al.
} 
macrosecuencia biográfica de 153 pezzi); pero será clausurado textual, literaria y formalmente 249 componentes después de su inicio, con la final canzone CCCLXVI de 137 versos que establece el total de esa sección o macrosecuencia iniciada con el año 17, completada en la página 137 y folio 72, verso del codice.

\section{La ratio sesquitertia en el Canzoniere. Sobre el tejido textual y el ciclo de il guanto.}

Si hoy nuestra lectura se construye también desde el conocimiento de las observaciones de Pötters sobre la forma del sonetto, sus números y sus posibles orígenes matemáticos, no dudo que los lectores próximos a Petrarca conocían mejor y vivían más religiosa y directamente que muchos de los lectores modernos del poeta de Arezzo la exégesis sobre las cifras de la pesca milagrosa. Para los interesados en el pensamiento numérico de Agustín y en su lectura sobre el Evangelio de Juan -cristianos creyentes y conocedores de la famosa razón áurea pitagórica, lectores atentos y motivados de las propuestas iniciales del poeta en los cuatro primeros sonetos-, acceder al reconocimiento de la cifra clave piscatoria redentorista y después a la lectura espiritual (o incluso teológica) de la divina proportione en el libro de rime sparse podía muy bien resultar bastante más sencillo, si no fácil. También Armisén 2011c.

Es hoy conocida la importancia del año 17 de su biografía literaria, espiritual y amorosa que se solapa con el 40 de vida de Petrarca; y también la señalada huella del mismo en los $R v f$ desde el inicio del sonetto CXVIII, texto pivote que cierra el año 16 de lunga guerra y eje cardinal que señala liminar el comienzo de ese año décimo séptimo, antes ya profético como el repetido 56 en cuanto decisivo para Escipión y su biógrafo. Eran datos explícitos y conocidos o muy accesibles. Los mejores lectores de Petrarca debieron advertir siquiera su particular interés.

Otras lecturas ofrecen mayor dificultad, pero no carecen de datos macrotextuales accesibles e indicios pertinentes que he venido señalando. La posibilidad de relación proporcional de la sección de los últimos 249 fragmenta con la cifra redentorista del 153+1 ó 154 del Evangelio de Juan y de la consecuente exégesis piscatoria de Agustín impone recordar siempre el sonetto IV en que «tolse Giovanni da la rete et Piero». La página inicial, fol. 1 recto $(1+2+3+4)$ culminaba armónica con la creación de Laura, momento desde el que se inicia, en el fol.1 verso y con el sonettoV del nombre de la amada, un proceso de búsqueda de 362 pezzi, unificado y significado por la data sacra (sonetto CCXI, vv.12-14) y, con ella, la ratio sesquitertia. Armisén 2008a: 59-60 y n. 8.

La doble macrosecuencia de 306 pezzi $(153+153)$ iniciada tras el sonetto LX parece confirmar el preciso interés posicional della conversione desiderata o prima preghiera cristiana del rinnovato proemio localizado en los sonetti LXI/LXII (Amaturo [1971] 1988: 281; Armisén 2004a: 95-96; 2008a: 53, 55 ss.; Picone 2007a: 161 ss. y 164-171). Se confirma y potencia la subsiguiente macroforma LXI-CCCLXVI, asimétricamente centrada también por la ratio 4/3 en el fol. 42, recto-el de los sonetti CCX-CCXIII- del codice d'autore de 72 folios numerados por el propio autor. Semeja, pues, presumible y probable que esa doble sesquitertia ratio (coincidente con la data sacra del sonetto CCXI, vv. 12-14 [como digo, sonetto V - canzone CCCLXVI: 362 pezzi] en texto literario y códice, 
fol. 42 recto) sea así mismo forma de composición de otros componentes, secciones o macrosecuencias del libro.

El caso de la sección de 306 pezzi (sonetto XXVI, vv, 9 ss. - sestina CCCXXXII, vv. 43-48) que en el textus delimita o trata la escritura poética dictada por Amor como tessere llama todavía nuestra atención $^{23}$. Petrarca parece haber situado con intención el tríptico de il guanto recamado ${ }^{24}$, sic.traduciones de Garcés (1591) y Crespo (1995).

El sonetto CCI ocupa la posición chiave que, probablemente con el recuerdo del sonetto I, v. 14, acompañado también por la vergogna, descubre la condición breve y vicaria de una caída, críptica y ritualizada. Una experiencia culpable menor de evidente interés simbólico: «Né mi riede a la mente mai quel giorno / che mi fe' ricco e povero in un punto» vv. 5-6 del sonetto CCI que coincidiría, en la escritura dictada por Amor de esa posible o hipotética sección, con la conocida ratio sesquitertia ${ }^{25}$. La tardía microsecuencia apoya el reconocimiento de la sección mencionada. En ella alcanza valor posicional «l'araldica squisitezza del 'bello aurato et serico trapunto», sostenida, quizá, por otros indicios simbólicos y lecturas varias, apuntadas por Pastore Stocchi en 1994: 251 ss. Su interés emblemático en el componente narrativo de los $R v f$ ha sido subrayado recientemente en las rápidas revisiones de Carrai y Fachard de Lectura Petrarcae Turicensis.

Difícilmente podemos olvidar ahora la descripción virgiliana del escudo de Eneas (Eneida VIII, vv. 626-728) señalado ab initio como textum «hastamque et clipei non enarrabile textum» (ibid., VIII,

\footnotetext{
${ }^{23}$ Pastore Stocchi 1994: 251 ss.; Armisén 2012: 78 ss., 83-88. Pese a las correcciones de Pastore sobre excesos biográficos y paráfrasis documentadas en la lectura del tríptico (G. A. Gesualdo, 1531), los comentaristas modernos (Santagata y Bettarini) insisten en la lectura del «ciclo del guanto» como microsecuencia narrativa destacada. Vellutello (1525, fols. 47, verso - 48, verso) reconocía su unidad narrativa. Pastore revisa el motivo del velo («bel velo», CXCIX, v. 12; comentado ya por Vellutello, que destacó las dudas del enamorado sobre su constancia en retener il guanto), apuntado antes en el sonetto XXXVIII, la ballata LIX o la canzone LXXII. En lo referido a la composición de los Rvf, creo también relevante la metáfora de la escritura poética como tessere comentada en 2012 y relacionada con la composición reticular y redentorista. No faltan detalles que como los «Lacci Amor mille...» (CC, v. 5) evocan el tesare / tessere y las reti de Amor (i laquei venatorum: Bettarini 2005: 929, n. v. 5 y 6). Tienen entre sus antecedentes próximos el importante sonetto CLXXXI «Amor fra l'erbe una leggiadra rete / d'oro et di perle tese sott'un ramo»y, 17 pezzi después, el inmediato «L'aura soave al sol spiega et vibra / l'auro ch'Amor di sua man fila et tesse», CXCVIII, vv. 1 ss.

${ }^{24}$ Entre el fol. 39, verso y el 40, recto del codice Vat. lat. 3195 hay un folio en blanco y sin numeración. Pudo resultar tanto del margen de seguridad previsto para la transcripción o de un proyecto modificado levemente (sustitución de una canzone por un sonetto, p.e) como también de la decisión de fijar el umbral del fol. 40 con el sonetto CCI en una posición calculada del codice.

${ }^{25}$ La chiave de la ratio sesquitertia (4/3) en la sección de 306 pezzi iniciada tras el sonetto XXVI la ocupa el texto 175 -en términos numéricos más exactos 174'85714- que en dicha sección corresponde al sonetto CCI «Mia ventura et Amor m'avean si adorno» del famoso «serico trapunto», del bordado sobre el guante de seda de Laura, de «...la mia nobil preda non più stretta». Armisén 2012: 35. El folio en blanco situado tras el 39 verso, quizá, fue destinado para un texto más extenso que finalmente no incluyó en ese espacio, y quizá anulado después con la ausencia de numeración autorizada. Como he dicho, la numeración de los 72 folios es solidaria de la ratio sesquitertia del codice. Armisén 2008: 58-64. Interesa considerarlo, dada la tardía fecha de transcripción de los sonetti del ciclo de il guanto. La postilla del Vat. lat. 3196 , traducida por Dotti (ed. 2004: 553), sitúa la recuperación del sonetto CXCIX, escrito 25 años antes, en la noche del 19 de mayo de 1368. Pensemos en las fechas de transcripción de esos fols. 39-40. Recordemos ahora la conocida postilla del mismo ms. sobre la recuperación del sonetto CCXI a las once de la noche del 23 de junio de 1369 que convierte también el sonetto de la data sacra en chiave calendariale de los $R v f$ apoyada por la misma ratio. Petrarca, ed. V. Pacca e L. Paolino 1996: 787 y 809-810; Santagata [1996] ed. 2004: 906-909.
} 
v. 625) divino, profético, trabajado por Vulcano y don último de Venus (Armisén 2012: 35) ${ }^{26}$. Pero aquí en el CCI de Petrarca valoramos un motivo cortesano con antecedentes trovadorescos y éxito conocido en el primer petrarquismo (Carrai 2007: 442-447). Era tema arquetípico ritualizado, marcado por su léxico y reconocible (pegno devuelto, añorado; y preda o furto, CXCIX, v. 14), culpable, doblemente culpable para el poeta y para algunos lectores). Un tejido textual y una escritura en la que spoglie, permite hablar de exuviae con antecedentes en Virgilio (Castelvetro, cif. Dotti ed. 2004: 553, n. v. 11); y de las relaciones metonímicas o incluso de la magia simpatética contaminante (Frazer [1890] 1981: 65 ss).

Sin duda, el problema nos llevaría, pronto y de nuevo, demasiado lejos. Remito a información recogida por Carducci-Ferrari: 287; y a la medida nota introductoria de Bettarini, ed. 2005: 931. Los lectores de Garcilaso reconocen el motivo inicial y dominante del soneto $\mathrm{X} \ll_{\mathrm{i}} \mathrm{O}$ dulces prendas por mi mal halladas» y su huella en la égloga I, vv. 353-365. Como es sabido, no faltan antecedentes para todos ellos.

\section{El cifrado enigma de la muerte de Laura, Providentia y divina proportione en los Rerum vulgarium fragmenta}

Centrémonos en la macrosecuencia de 249 textos iniciada desde el sonetto CXVIII del año 17 de su pasión amorosa (iniciada el 6 de abril de 1327) y en el año 40 de vida de Petrarca, nacido el 20 de julio de 1304. Valorando la pertinencia de la numerología de Agustín y sus lecturas del 17 y el 153 evangélico, considero que la localización inicial y final del segmento, sección o secuencia -iniciada en el sonetto «Rimansi a dietro il sestodecimo anno» (Santagata ed. 2004: 544) y acabado con el Canzoniere y en la canzone CCCLXVI- cumplen (sobradamente) con la condición necesaria de ser momentos cardinales significativos, nuevo principio y final absoluto, destacados con intención en el continuum de 366 pezzi.

La coincidencia solo muy aproximada de la cifra evangélica del 153 con la proporción áurea en la canzone CCLXX o la más exacta del 153+1 evangélico y agustiniano, con la conclusión del sonetto CCLXXI del año 21 de la muerte de Laura -año recordado después con intención en el texto que concluye la que denominé secuencia biográfica (CCXI-CCCLXIV) de 153 pezzi-, será ahora decisiva en la lectura formal del macrotexto. La ratio de la macrosecuencia de 249 unidades establece el sentido de esa sección final y focaliza nuestra atención. Como hemos visto, la huella operativa e implícita del 153 no puede considerarse forma exclusiva del Canzoniere de Petrarca.

\footnotetext{
${ }^{26}$ También el texto de Virgilio puede estar (o parece) ajustado por proportiones y rationes. No sabemos, pese a sus conocidas anotaciones, qué noticia alcanzó Petrarca sobre su composición formal. En este caso, si consideramos las propuestas de Duckworth sobre su forma, podría tratarse de la recurrente (o modular) aparición de la sección áurea. G. Duckworth, en un importante y conocido trabajo que nos interesa por muchas razones ([1962] 1980: 146, números 621624), ha señalado proporciones muy próximas a la sección áurea de la unidad (0’618) en los versos que tratan el tema del escudo de Eneas en el libro VIII de la Eneida (vv. 626-728). Petrarca había trabajado desde su juventud la descripción del escudo, interesado en el texto, sus antecedentes e información histórica como prueban las postille del Virgilio que le perteneció y las de los comentarios de Servio sobre la Eneida, Petrarca ed. 2006: vol. I, 412-415; vol. II, $912-919$.
} 
Sin embargo, arroja nueva luz sobre la presencia emergente de Providencia en la composición de los $R v f$. El proceso textual y espiritual reiniciado desde el año 17 y el sonetto CXVIII, al menos cronológicamente, se cierra «pentito et tristo de' miei sì spessi anni, en 1358 (sonetto CCCLXIV, que completa y resume la macrosecuencia biográfica [CCXI-CCCLXIV] de 153 pezzi); pero será clausurado textual, literaria y formalmente tras 249 componentes con la canzone CCCLXVI de 137 versos, en la página 137 y folio 72, verso del codice. El sonetto CCCLXIV «Tennemi Amor anni ventuno ardendo» reclama, de nuevo y ya en el cierre del Canzoniere, la atención del lector sobre el 21 aniversario, antes evocado con plural intención en el sonetto CCLXXI:

$$
\begin{aligned}
& \text { L'ardente nodo ov'io fui d'ora en hora, } \\
& \text { contando, anni ventuno interi preso, } \\
& \text { Morte disciolse, né già mai tal peso } \\
& \text { provai, né credo ch'uom di dolor mora. } \\
& \text { Non volendomi Amor perdere anchora, } \\
& \text { ebbe un altro lacciuol fra l'erba teso, } \\
& \text { et di nova ésca un altro foco acceso, } \\
& \text { tal ch'a gran pena indi scampato fôra. } \\
& \text { Et se no fosse experïentia molta } \\
& \text { de' primi affanni, i' sarei preso et arso, } \\
& \text { tanto più quanto son men verde legno. } \\
& \text { Morte m'à liberato un'altra volta, } \\
& \text { et rotto 'l nodo, e 'l foco à spento et sparso: } \\
& \text { contra la qual non val forza né'ngegno. }
\end{aligned}
$$

Si bien W. Pötters, que prestó atención muy particular a estos sonetti por su explícita condición biográfica y su función demarcativa, entendía (1987: 63 ss.) que la cronología, explicita y ficticia del Canzoniere, o los poemas del año 17 (del CXVIII al CXXII) podían tener alguna relación aritmética con las 154 sílabas regulares de la forma sonetto, creo más bien que la fechación con el sonetto CCLXXI del 21 aniversario (153/154 pezzi después del inicio de ese año en el CXVIII) señala un centro y axis nodal de macrosecuencia o sección significativa en los $R v f$, cifrada espiritualmente por la numerología de Agustín.

Valorar la huella espiritual y numérica de Agustín desde 2004, tras la localización en 2008 de la ratio sesquitertia en el sonetto CCXI y la data sacra, permite ahora plantear con algún crédito la presencia significativa de una ratio que apoya la doble presencia de Morte como designio o Providencia divina, factor positivo cifrado con el código desvelado por el obispo de Hipona. Ha de recordarnos el confesional «L'amar m'è dolce, et util il mio danno», CXVIII, v. 5, que comento en este mismo trabajo.

En mi opinión, la relación proporcional de la cifra de Agustín con el total parcial de los 249 últimos componentes del Canzoniere, tras la muerte de Laura y la canzone CCLXX (Armisén 2004a: 89), sitúa posicionalmente en los versos finales del sonetto CCLXXI la significativa declaración con la sugerencia de la Providencia divina, responsabilizada pronto en el sonetto IV de la creación de 
Laura; y silenciosa, formalmente propuesta ahí, precisamente en el folio 56 del codice, como causa de la solución final. Los considero datos cifrados relevantes y significativos, apoyados numéricamente.

La cifra de la profecía sobre Escipión, comentada por Macrobio, era conocida por Petrarca -que anotó el ms. de sus Commentariorum in Somnium Scipionis (Nolhac [1892] 1965: I, 157, 159 passim; II, 103-104 et al.)- y por no pocos lectores de los Rvf. Armisén 1982 y 2013: 228-229; vid. Macrobio, ed. L. Scarpa 1981: 48; y M. Armisen-Marchetti Introd. ed. Macrobe 2001: LXVI ss. y en particular p. LXXI y n. 184. Como veremos, Sannazaro y Bembo, Garcilaso o Boscán conocían esos números y podían reconocer también su valor funcional.(Armisén 1982 y 2011c)

La atención a las medidas y cifras implicadas en la forma sonetto ha de parecer más aventurada, sin duda. Se apoya en la conveniencia de valorar los vínculos de la geometría o de la música y la Armonía (De musica libri VI) con la numerología de Agustín, con la búsqueda espiritual, con la confirmación de su amor o con la mutatio (sonetto CCXIII, v. 14 [v. 56 de la página]; y fol. 42, recto), con las descripciones de Laura y también, sólo generalmente, con la forma poética modular del Canzoniere $^{27}$, unificado por la misma ratio sesquitertia.

Resulta consecuente concluir que la conocida razón pitagórica áurea permitirá entender mejor la localización cifrada de la canzone CCLXX [texto número 153 de la mencionada secuencia] y el sonetto CCLXXI [texto 154] entre los 249 fragmenta que restan del libro desde «Rimansi a dietro il sestodecimo anno / ...» ${ }^{28}$. De modo que la posibilidad cierta de que la proporción entre el 153/154 de Agustín (In Iohannis..., 123, 2; sic. Evangelio de Juan, XXI, 9-13) y los últimos 249 fragmenta de los $R v f$ actualicen en la obra de Petrarca una trabajada realización (proportio habens media et duo extrema...sic. Pacioli), de la más conocida como media y extrema razón (1'618033...Pitágoras) se hace evidente. Vid. Aristóteles sobre los pitagóricos y el número como substancia de las cosas, causas material y eficiente [Metafísica, I, 5; ed. 1970: 34-45] o Iamblico, Euclides [Elementos, VI, 30-31],

\footnotetext{
${ }^{27}$ Las dudas que resultan de la regular omisión de referencias al De musica libri VI -no sé si acertadamente...- podrian llevar a la idea de que Petrarca no conoció esa obra de Agustín. En todo caso, las propuestas sobre la relación de la armonía con la virtud de Agustín (en su caso las virtudes cardinales, en concreto) tienen coincidente reflejo en la atención sostenida de Petrarca en los $R v f$ a su progresión en las virtudes teologales. Ejemplifica todavía esa carencia de referencias al texto de Agustín la reciente revisión «Quanto e quale Agostino», Giannarelli 2004: 1-17. También ajeno al De musica y sin apenas referencia al importante sonetto CCXIII «Gratie ch'a pochi il ciel largo destina», vv. 5-8, que incluye entre las gratie de Laura su relación con «e 'l cantar che ne l'anima si sente» vid. Capovilla 2007: 115, 117-118. Armisén 2011: 24.

${ }^{28}$ Vid. «Le misure auree» en W. Pötters 1998; 104 ss. Aunque ajeno en sus trabajos a la influencia de la numerología de Agustín y a la propuesta que planteo ahora, Pötters sí a considerado la posible relación de la famosa sección áurea con la medidas de la forma sonetto. Parece una observación a estudiar. Subrayaré más el interés posicional, temático, del sonetto di preghiera CXVIII -que el mismo Pötters, años antes, valoraba como inicial (1987: 63 ss.)- en una fecha simbólica sagrada, cifrada con el pensamiento numérico de Agustín; y, después, los fragmenta CCLXX y CCLXXI, dada la probable relevancia compositiva de la distancia (153/154) que separa esos dos poemas in morte del inicio del año 17. Sobre ambos textos, véase también Bettarini 1987: 225-244. Su interés se refuerza con la oportunidad de entender relevante, en términos de composición narrativa, la condición formal unitaria de los 249 últimos textos de los Rvf. Señalar el interés de Sannazaro en el sistema de aniversarios que toma de Petrarca y en el año 17 de los Rvf importa ahora por muchas razones. Algunas de las cifras de los $R v f$ no eran inaccesibles ni ignoradas en el siglo XVI. No olvidemos que ese año 17, anhelado mucho después por Sannazaro en el sonetto 98, todavía lo subraya Petrarca después en los vv. 1-4 del sonetto CXXII. Sobre su huella en los Sonetti et canzoni (1530), Armisén ( [2011c] 2014/2015, pend de publ. Vid. Canzoniere ed. Santagata, 2004: $544,569,1097$ y 1107.
} 
Boecio, etc. De modo que evaluar tentatívamente en sus precisos y exactos límites esa ratio y la posibilidad matemática de su lectura operativa en la mencionada sección de los $R v f$ es ahora obligado.

Como macrosecuencia del Canzoniere, simbólica y temáticamente reestructurado desde el aniversario que señala el principio del año 17 de su pasión, ofrece una lectura unitaria y proporcional a estudiar. La proporción de la extrema razón 249:154 [1'61688...] (exacta casi hasta las milésimas ...) se completa, tal vez, con la correspondiente y ya menos precisa media razón 154:95 [1'62105...] Nos permite reconocer una macrosecuencia final significativa: unificada por ratio, en términos numéricos solo muy aproximada. Pero quizá «bastante» exacta si atendemos a su condición propia en cuanto números irracionales; más aún si la comparamos con otras propuestas conocidas de su aplicación en las artes espaciales o visuales de menos perceptible, imprecisa o más difícil cuantificación última.

Aún podemos decir más. Si, considerando cada texto unidad con sus correspondientes centésimas -recordando el caso de la ratio sesquitertia ubicada en los Rvf mediante la declaración de la data sacra del CCXI, vv. 12-14. Armisén 2008a: 60 y n. 8-, ...y si también tomamos como referencia el inicio de la enigmática conclusión del sonetto CCLXXI, v. 12-14 (153'85 / 95'14 en los 249 fragmenta), el ajuste de la extrema razón (249: 153'85 = 1'61845...ahora sí, exacta hasta las milésimas) y el de la media razón (153'85: 95'14 = 1'61709...) se hacen ambos todavía más precisos. En mi opinión, con ser ya datos concluyentes, no son todavía la mejor prueba de su presencia.

La señalada semejanza o ritual coincidencia formal de las declaraciones sobre las fechas del primer encuentro (CCXI, vv. 12-14) y la muerte de Laura (CCCXXXVI, vv. 12-14) confirmará indirectamente una complementaria función simbólica con el sonetto CCLXXI en términos de composición significativa.

Si la famosa data sacra cifraba en los $R v f$ el componente litúrgico o calendariale por referencia a la vita Christi y/o el año litúrgico (en algunos pezzi destacados), la muerte de Laura lo marca posicionalmente en el proyecto formal de Petrarca y -lector reconocido de la Metafísica que poseyósoluciona formalmente su causa reconocible en «términos pitagóricos y/o aristotélicos» como ratio y razón espiritual con la declaración sobre las consecuencias de esa pérdida CCLXXI, vv. 12-14 en la macrosecuencia CXVIII-CCCLXVI:

Morte m'à liberato un'altra volta,

et rotto 'l nodo, e 'l foco à spento et sparso:

contra la qual no val forza né 'ngegno.

La declaración que cierra el sonetto CCLXXI, vv. 12-14 establece y focaliza la reiterada función de Morte como paradoja y enigma, pero no declara la acción de Providencia que se desvela mejor en términos de cifrada composición formal.

Su exacta confirmación aritmética puede obtenerse mejor directamente. Dividir el total de 249 pezzi por la famosa aurea ratio permite verificar que la declaración sobre los efectos de Morte y de la muerte de Laura ocupa con exactitud incuestionable y discreto énfasis la posición chiave. Y Petrarca, estableciendo su función como enigma determinante en la lectura, la delimita y localiza en los $R v f$ en 
relación significativa tanto con el 17 (y el año 40 de Petrarca) como con el 153/154 de la exégesis evangélica de Agustín. Concluiremos que la aurea ratio (1'618033 ...) se revela como clave operativa de Providencia (y también... como divina proportione anterior al libro de Pacioli [1509]) en el codice d'autore acabado de $1374^{29}$.

Alcanzada con exactitud final la mejor prueba, no creo necesaria otra verificación. Si aceptamos la oportunidad e interés de interpretar la sección de 249 pezzi (CXVIII-CCCLXVI) que, desde el inicio del año 17 delimita la transformazione, volviendo sobre la crisis marcada por la desesperación en la CCLXVIII, atendiendo a la importancia decisiva que la muerte de Laura cobra en la resolución del caso ...hemos de concluir que la famosa sección áurea permite acceder a una declaración que focaliza una clave espiritual decisiva de los $R v f$. La conocida como media y extrema razón parece confirmar su presencia operativa en la composición del Canzoniere, ajustada por la cifra redentorista de Agustín.

Tras la primera mención de la condición providencial de Laura y de su nacimiento en el sonetto IV, su desaparición - temida en los Rvf y adelantada como vaticinatio [post eventum] por Augustinus en el Secretum (Armisén 2013: 206-213, et al.)- se establece como solución providencial y revelación formal, marcada con precisión en la dovela chiave por la divina proportione. Apoyada y sostenida por la forma numérica de otras macrosecuencias cifradas también por los números de la exégesis de Agustín (por ejemplo la de las enfermedades de Laura [XXXI-CCCXXXVI]), con la ratio de la proporción áurea se impone velada y formalmente el triunfo de la Providencia divina sobre «l'empia Fortuna» (CXVIII, v. 7), la conclusión de la condición providencial de la temida «Morte» (CXVIII, v. 8).

De acuerdo con los datos mencionados, el interés de la final declaración de alcance del CCLXXI, vv. 12-14 (Santagata ed. 2004: 1107-1108 y 1109, n. v. 12; Bettarini 2005: 1235-1237), próximos los antecedentes señalados por Chessa de los lacci y nodi (2005: 155 ss.; CCLXX, vv. 56-62), tras el congedo que cerraba con intención la canzone «Amor, se vuo' ch'i' torni al giogo antico» centrada por «la topica del laccio o del nodo» que «...la Morte ha definitivamente 'sciolto'» (Fenzi 2007: 600), expresando aún su voto «Del laccio d'òr non sia mai chi mi scioglia», vv. 61 ss., se potencia numérica, biográfica y posicionalmente con el sonetto «L'ardente nodo ov'io fui...» y con la ratio de la famosa sección áurea en su segundo terceto. Creo que el interés operativo del sonetto CCLXXI o su declaración final son evidentes. La exactitud de la proporción resulta, en principio más que satisfactoria, la valoro en este caso como casi incontestable.

No perdamos de vista que -conocedores de que el hombre no puede manejar con exactitud absoluta los números irracionales-, para algunos matemáticos el número áureo presenta el peor grado

\footnotetext{
${ }^{29}$ Armisén 2008a: 60-63 y nn. 7-11. Su exactitud fuera de dudas resulta ahora de dividir el total de esa macrosecuencia de 249 pezzi [CXVIII-CCCLXVI], comenzada con el año 17 desde el verso inicial del sonetto CXVIII, por la conocida sección áurea: $249: 1 ' 618033 \ldots=153$ ' $89055 \ldots$ No cabe, pues, hablar solamente de aproximación. Es también la solución más exacta posible de la ratio en ese total. El resultado coincide plenamente con el último terceto del sonetto CCLXXI, texto 154 de esa macrosecuencia.
} 
de «aproximabilidad», lo que ha llevado a describirlo como el número más irracional. Su aplicación para la expresión de diversos efectos divinos en la cultura clásica y renacentista, mencionada ya por Panofsky sin precisiones en 1921 (1995, ed. 2006: 103), parece confirmar repetidamente esa adecuación. La semejanza con la formalización señalada en el 2008 de la ratio sesquitertia en la data sacra del sonetto CCXI, vv. 12-14 se hace evidente.

Vellutello no atiende a la relación de Petrarca con la división en dos partes del Canzoniere ni al ordo del codice, propuesta por Bembo e impreso por Manucio en 1501 (Belloni-Pulsoni 2006: 149 et pass.), obviamente ajeno a la posibilidad de una composición macrotestual intencional y válida o autorizada. Manteniendo en su reordenada edición la contigüidad de CCLXX y CCLXXI por su perceptible coincidencia temática, biográfica y situacional (ed. 1525: 142, recto; 1538: 114, recto), explicará en 1538 con una breve ampliación de su primera espositione el rechazo de esa nueva tentación en «L'ardente nodo ov'io fui d'ora in hora», verso inicial que nos hace pensar también ahora en el importante CCCXLIX, v. 1. Un sonetto CCLXXI cuyo contenido (funcional) comenta el lucchese, en esta ocasión excediendo los límites de su contenido explícito, con ayuda de una curiosa fórmula de corte proverbial «... ma nuova rete vecchio uccel non prende».

Trabajando en el códice de autor recuperado, valorando el apoyo de la macrocomposición y la localización de la ratio que formaliza mejor la relación de sus referentes causales, los comentarios mencionados, antiguos y modernos, semejan hoy una lectura perfectible.

La lectura propuesta se construye considerando las tesis teológicas y numerológicas del autor de las Confessiones. Providentia (De musica VI, 11, 30 y 33; y sobre todo ibid. VI, 17, 56-58; Confess., VI, 5, 7; y VII, 7, 11) había sido relacionada por Agustín con el orden numérico de la creación (De civitate Dei, IV, 23; y V, 11).

Su presencia fue adelantada en el sonetto IV, donde Petrarca introducía en los $R v f$ el tema de la Gratia y establecía con perceptible claridad -siquiera en mi lectura de 2004-, unida a la humilitas, la condición funcional figurada de Laura desde su nacimiento mediante el antecedente redentorista y piscatorio de «... Giovanni... et Piero,» significados instrumentos de la redención. Ambas (Providentia y Gratia) reaparecen después, aunque la primera lo haga de forma elidida, trabajado fruto de la lectura de su composición. Como vemos, el numerus y las interpretaciones numéricas de Agustín tienen mucho que ver con ello. Pensemos también que caritas es amor, tocado, acompañado o inspirado por la Gratia.

La composición modular o pautada con la numerología redentorista sostiene y confirma el reconocimiento de la ratio. No olvidemos que la forma numérica es elemento constitutivo de la secuencia. Providencia se afirma cifrada aquí por el 17 y el 153 (o, mejor aún, el 153+1) de la exégesis de Agustín en el cierre de la canzone CCLXX o los versos finales del sonetto CCLXXI de Petrarca y en relación directa con la muerte de su dama. Contrástese J.-Y. Lacoste [1998] 2007: 45 ss. y Arendt [1929] 2001: 36 ss. y 58 ss. et al; Armisén 2004a: 83 ss. y 89.

Reconocer ahora la coincidente presencia anterior del 153 piscatorio en la casi exacta $\sqrt{ } 3$ [ 265:153] que, al parecer, marca en repetidas ocasiones las proporciones simbólicas de la mandorla 
(in vesica piscis) es más que oportuno. Su relación con el símbolo cristiano pictórico y escultórico o arquitectónico, que tantas veces señala el umbral del espacio sagrado, permite siquiera advertir que trabajamos con cifras significativas y formas geométricas con precedentes conocidos de presencia anterior y repetida. Su más que frecuente aplicación imprecisa no puede extrañarnos. Sirva, en todo caso, para advertir siquiera que en el Canzoniere -su aplicación del sistema numérico cristiano cifrado con el 153- cuenta con referentes formales y otros antecedentes que no conviene ignorar, dado que el código numérico en que se formaliza reaparece después (con función verificable) en textos y espacios históricos que lo actualizan con intención.

La divina proportione de la macrosecuencia CXVIII-CCCLXVI tiene, probablemente, dispares antecedentes crípticos de uso próximo, semejante y repetido en la pintura y arquitectura religiosas de esos siglos. La mencionada mandorla era incluso un motivo conocido en la ilustración de códices. No es la ocasión para detenernos en ese problema. Después, como he dicho, la presencia de esas mismas formas simbólicas, proporciones y cifras en la solución de Bernini para la Piazza di San Pietro (Armisén 2004b: 90, 101 et al.; y n. 28) confirmará aún en el siglo XVII su aplicación, adecuación y la vigencia posterior. Esa composición de la sección o macrosecuencia CXVIII-CCCLXVI [249:153/154...) tenía antecedentes en la criptología medieval cristiana, con repetidas formas numéricas (aritméticas, espaciales y arquitectónicas). Glosadas con breve y cauteloso énfasis en el cierre de la Arithmologia de A. Kircher (Roma, 1665), pero concebidas en fechas anteriores reaparecen todavía en el Vaticano antes de 1680.

La explicación del tema del nacimiento y muerte de Laura y su positiva función en la vida u obra de Francesco Petrarca, se ofrece en la composición formal de los Rvf (macrosecuencia CXVIIICCCLXVI) como paradójica, silenciosa y cristiana solución del caso. Aventurándonos a considerar el Agustín del sonetto XL (y más aún el Augustinus del Secretum) como aventajado y supuesto «primer lector de las rime sparse», admitamos que el profético magister del diálogo tenía datos para su mejor lectura como respuesta de Francesco.

Hoy, todavía atentos a sus ecos, puede hacernos pensar también en la explicita y semejante opción de Boscán, similia similibus curantur, comentada en la canción CXXX [102] de 153 versos. Con el referente del símil central de Lázaro (In Iohannis evang., tract. 49, 1-28; Ludolfo..., Vita Christi ed. 1530: III, caps. XVII y XVIII), cierra, resume y explica el sentido espiritual del primer canzoniere castellano. La identificación del Lázaro, pecador redimido, como símbolo del poeta petrarquista hispano, reaparece en la poesía de Góngora y tiene vida posterior. Armisén 1982: 405-411; 2004a: 7681;2011: 10. Tuviese o no el barcelonés otros modelos, la influencia del libro de Petrarca es reconocida y dominante: la cifra evangélica codificada por Agustín difícilmente será en el Libro II de 1543 ajena por completo a su reiterada presencia anterior en los $R v f$. 
9. El arquetipo y sus ecos. La huella de Macrobio en texto literario y codice. El 56 de Escipión y Augusto en el «sonetto 153». «Se Virgilio et Homero avessim visto» (CLXXXVI, Rvf). La concentración de efectos en la loa del CCXIII. EI timor del sonetto CXVIII y la pareja CCLXX / CCLXXI: Providentia y divina proportione en el fol. 56 recto del codice Vat. lat. 3195. Los De musica y sus coincidencias con el Secretum.

La lectura de Petrarca propuesta por el ms. Vat. lat. 3195 se convierte, tras la muerte del poeta, en solución definitiva. El destino y fortuna cambiante de ese códice han marcado los límites del conocimiento de un libro de poesía con doble forma autorizada de lectura en sus composiciones finales que -ignorada o perdida en su exacta transcripción de las postille, solo ocasional y reconocida por muy pocos, hoy documentada parcialmente (G. Belloni 2004: 80 ss.; A. Soldani 2006: 216 ss., 246-247)se establece pronto, siquiera de forma incompleta y pese a las dudas sobre numerosos aspectos formales, como modelo canónico de colección narrativa de poesía lírica.

El presente estudio asume sus límites. Es solo una investigación parcial sobre esos aspectos formales cifrados y posicionales, menos conocidos, desatendidos o no trabajados por la crítica filológica moderna. Aunque intento destacar posibilidades textuales objetivas, recuperando aportaciones descuidadas o poco valoradas, propongo también lecturas relevantes de la primera forma original. Sin conocer y repasar las aportaciones de numerosos estudios pasados y recientes sobre el Canzoniere este trabajo hubiese sido irrealizable. Trabajamos viejos temas en un constante proceso de revisión, centrados, orientados y limitados por la información precedente.

La forma secuencial marcada por el 17 y el 153+1 de la exégesis de Agustín parece confirmada en los conocidos versos finales del sonetto CCLXXI:

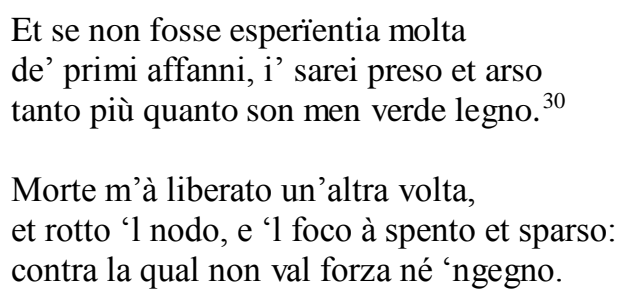

En la macrosecuencia última y definitiva de 249 fragmenta iniciada con el sonetto CXVIII y el año décimo séptimo, el sonetto CCLXXI del ya cumplido 21 aniversario, tras la referencia a la nueva tentación de Amor «ebbe un altro lacciuol fra l'erba teso», v. 6 y con su declaración final sobre la providencial, reiterada acción de Morte -«Morte m'á liberato un'altra volta / ...»- ofrece la más exacta aproximación posible en dicha secuencia a la sección áurea. Considerada la relevancia temática demarcativa de su primer y último texto, difícilmente será un hecho casual y por completo ajeno a la voluntad compositiva del poeta. Recuperar información sobre su reconocimiento o sobre los lectores

\footnotetext{
${ }^{30}$ Según Bettarini (ed. 2005: 1235) es «Primo sonetto delle rime "in norte" che riprende lentamente a scandire il fluire del tempo...d'ora in hora, / contando...». Subraya la nostalgia de un imposible regreso a la juventud. Señalando la estrecha relación con la canzone anterior, el verso 8 lo anota Santagata (2004: 1108-1109) como referencia que contrasta con el primer verso «L'ardente nodo...» y en cuanto alusión a su capacidad de volver a arder como leño seco. Antes he apuntado la repetición de la fórmula inicial en el v. 1 del sonetto CCCXLIX.
} 
que pudieron acceder a las formas de composición que la sostienen sería un difícil trabajo que creo útil.

Un dato a valorar se refiere a los problemas implicados en esa aplicación de la ratio. Si la aurea proportione construye o sostiene la lectura espiritual de los Rerum vulgarium fragmenta desde un año, el cuarenta de vida, marcado por el sonetto CXVIII, esa forma esencial se hace reconocible desde, con y por la presencia verificable del 17 y el 153/154, cifras conocidas por Petrarca y alguno de sus lectores propios como fundamentales de la numerología de Agustín ${ }^{31}$. La condición indicial del sonetto XL en que la declarada influencia del magister en la construcción textual de la obra se une a la petición de ayuda debe ser recordada. Armisén 2012: texto y nn. 3, 4, 7 y 15.

$\mathrm{Y}$, en términos de composición simbólica, formal y grafico-visiva, puede ser también oportuno señalar que si el sonetto XL se transcribe en el umbral del fol. 10 del codice de autore, el CCI de $i l$ guanto («Mia ventura et Amor m'avean sì adorno / d'un bello aurato et serico trapunto», vv. 1-2), del «guante recamado»-goce fugaz, prenda de la amada Laura brevemente retenida por el enamorado culpable, don o gracia de Amor, según reconocen las traducciones de Garcés (1591) y Crespo (1995)-, así mismo textus en que la sección sobre el tessere como escritura de 306 pezzi (XXVICCCXXXII) alcanza su ratio sesquitertia, lo trascribe el propio autor como cierre del fol. 39 y en el correspondiente umbral del fol 40. Supra n. 24. Armisén 2012: 83 y nn. 4, 5 y 14.

Fenzi insistía recientemente en el interés de la canzone CCLXX. Destaca todavía (2007: 595 ss.), con otras razones, la importancia de la inserción del sonetto CCLXXI entre los textos iniciales in morte y la estrecha relación de ambos. En relación discutida con la superación o el rechazo de una nueva oportunidad amorosa (tentación personal de Francesco / nueva opción literaria del poeta), reconocer en el Canzoniere una forma secuencial probable, en chiave narrativa agustiniana, marcada desde el sonetto CXVIII con el final del año 16 por el inicio del 17, el temor a la muerte de su dama (recordémoslo una vez más) y la confirmación positiva de su amor por Laura, volviendo sobre mis propuestas del 2004a: 93-94 ó 2008a: 49-51, et al. resultará oportuno. Secretum ed. 1992: III [137-154 et ss.] Armisén 2013.

\footnotetext{
${ }^{31}$ El caso propuesto tiene antecedentes en la poesía clásica que conviene mencionar, aunque no tengamos información sobre su trasmisión y reconocimiento. Tal vez sea Corrado Bologna (1998: App. Bibliog. 121-122, et al.) el único que, en su caso en relación con Dante, ha prestado atención explícita y reconocida a esos precedentes. La precisión cuantitativa de la divina proportione en la macrosecuencia CXVIII-CCCLXVI del codice d'autore de los Rvf no es cuestionable en su exactitud rigurosa, si la contrastamos con otras numerosas señaladas en propuestas sobre los textos de Virgilio. Véase al respecto el artículo de G. Brugnoli y R. Scarccia en la Enciclopedia Virgiliana, 1987: vol. III, 792-793. La ambiciosa pretensión de G. Duckworth de estudiar y proponer (Chapter 4 [1962] 1980: 45 ss.) la sostenida huella de la media y extrema razón en 1040 segmentos o fracciones de la Eneida (y en otros textos) se permite (entiendo que voluntaria y calculadamente) considerar una precisión laxa (0'600/0'640) de la más exacta sección áurea de la unidad (0'618). Esa laxa pauta recurrente, que valora como intencional por razones de frecuencia (ibid. 1980: 45-48), ha sido lógicamente cuestionada en estudios posteriores. Una revisión (no la única) de ese trabajo y de sus antecedentes en relación con la composición arquitectónica de las Bucolicas (P. Maury, 1944) y con la primera Georgica (Le Grelle, 1949; etc.) puede verse en Miniconi 1963: 263-272; et al. No hacen falta tantos casos como suman las tablas de Duckworth ([1962] 1980: Appendix F 111-117 y G 117-118; Tables I-VIII, 121-173) para que podamos, al menos, señalar aquí su interés como (posible y probable) antecedente clásico de la composición modular y pautada que estudio en los Rvf. Miniconi 1963: 264267, 271-272 et al. No dudo que la intención de Petrarca, conocedor de Vitruvio, es otra diferente. La aplicación sostenida de la numerología cristiana de Agustín en los Rvf sí resulta acorde con sus creencias e información documentada.
} 
No faltan pruebas de que, más allá de sus implicaciones espirituales, tras el conocido antecedente de Dante, con la crisis resultado de la muerte de Laura, la nueva tentación amorosa se convierte después en motivo nodal repetido, en función cardinal característica del modelo o arquetipo narrativo de biografía de poeta enamorado ${ }^{32}$. Si es posible reconocer su huella en la poesía castellana de los siglos XVI y XX, no dudo que sus ecos en la poesia italiana serán varios o incluso numerosos.

Petrarca defiende lo positivo o benéfico de su amor contra los consejos del Augustinus del Secretum. Lo plantea desde el sonetto CXVIII, aunque en otros términos fijados con eficacia por la conocida declaración de su v. 5, «L'amar m'è dolce, et util il mio danno», unida a la inmediata declaración en los vv. 7-8 de sus temores por la muerte de Laura, según he advertido en las primeras páginas de este trabajo.

En cuanto afirmación paradójica, vinculada a esos mismos temores que centran la macrosecuencia $a b$ initio, el lector - piadoso o no...- puede muy bien recordarla todavía 153 textos después. Y «Morte m'à liberato un'altra volta», v. 12 del sonetto CCLXXI, objeto de particular atención crítica, verso cuya ambigua ricchezza interesa a Fenzi ([1998] 2003: 163-164; después 2007: 597-601; y 2008: 117-119), se presenta como aparente paradoja explícita y queda cifrada formalmente con intención. Como he dicho, me parece ahí una huella trabajada por Petrarca, semivelada pero destacada (y más aún duplicada) de Providencia cuya presencia hubo de ser reconocida por lectores atentos.

Si la lectura propuesta por Vellutello de los que conocemos como canzone CCLXX y sonetto CCLXXI ejemplifica bien la importancia que la comprensión directa y más común presta a las coincidencias temáticas, situacionales o relaciones intertextuales de algunos textos destacados, la interpretación avanzada de esos mismos fragmenta en sus implicaciones espirituales y narrativas se apoya en el codice de autor con la composición numérica, unitaria y macrotextual que el comentarista lucchese ignora. Las supuestas incongruencias señaladas en 1525 parecían observaciones pertinentes, pero eran también razón, y quizá excusa o justificación de su pretensión crítica personal que le llevó a anotar profusamente, reordenar y editar los textos de Petrarca.

El sonetto CXXII «Dicesette anni à già rivolto il cielo» declaraba el interés de ese año iniciado en el CXVIII; y, partiendo de un proverbio conocido (CXXII, v. 5), marca de nuevo o subraya la relación de la reiterada cifra de Agustín con la dubitativa expresión de sus deseos en los últimos versos:

Oïmè lasso, e quando fia quel giorno che mirando il fuggir degli anni miei, esca del foco, et di s'lunghe pene?

\footnotetext{
${ }^{32}$ Boscán, consciente de la inadecuación o difícil posibilidad de integrar el tema de la muerte de la dama en su canzoniere castellano, alude contrastivo a la generosidad divina que la mantiene en el mundo como reflejo divino; y se afirma en la esperanza de que tardará en reclamarla. Es el soneto que cierra la microsecuencia central sobre la creación de su dama LXXX [52], vv. 12-14. El inmediato soneto LXXXI [53] reinicia el continuum narrativo, consecuente con un enamorado deslumbrado, silenciado y paralizado, dominado por sus carencias. Junto al precedente dantesco del motivo de la nueva tentación post mortem en Vita nuova, señalado por la critica del Canzoniere de Petrarca, recogido por sus editores y revisado por Fenzi (2008: 117 ss.), señalaré ahora su huella moderna, irónica y laica en el soneto III de «Los sueños dialogados», fábula de identidad de Antonio Machado en cuatro sonetos con numerosos componentes petrarquistas incluida en Nuevas canciones (1924). Vid. Armisén 2008b: 36-39, 46-49 et al.
} 
Vedrò mai il dì che pur quant'io vorrei quel'aria dolce del bel viso adorno piaccia a quest'occhi, et quanto si convene?

Los anhelos, las pretensiones y las aspiraciones se suceden, contrastan, se encadenan o transforman como las peticiones en el continuum. El «... e quando fia quel giorno / que mirando il fuggir degli anni miei...», vv. 9-10 del CXXII de la Correggio -eco reconocido de un celebre «passo ciceroniano» anotado por Dotti (ed. 2004: 354)- parece también antecedente significado del «sarei contento di sapere il quando, / ma pur devrebbe il tempo esser da presso», vv. 8-9 del CCCXLIX (Rv6: ed. Santagata 2004: 1343).

Nos permite reconocer ahora que, ahí en la CXXII, expresaba in vita y en el año 17, iniciado poco antes con el CXVIII que enmarcaba el temor del enamorado, antes ya apuntado en otros textos, un premonitorio deseo de alcanzar lo que in morte solicitará después el sonetto CCCXLIX. Lo hará entonces, con énfasis final y después de una transformazione (CCXIII, v. 14), desde una situación personal y espiritual distinta, tardía si atendemos al componente biográfico del ordo, pero en una posición marcada de nuevo, a 17 textos del cierre y coincidente con el módulo de 17 [de hecho, la 289 ó $17^{2}$ en la macrosecuencia de 306 pezzi LXI-CCCLXVI], esa misma cifra potenciada que ya conocemos. Armisén 2008a: 52 ss.; 2013: 206 ss. La imbricación secuencial macrotextual suma sus efectos.

De modo que la recurrente presencia del módulo y de la composición numérica agustiniana se hace presente reiteradamente en las rime sparse, puede ser rastreada con mayor o menor rigor por distintas vías. Advirtamos ya que no faltan datos a considerar en sus imitadores italianos. El interés final del sonetto $98 \ll \mathrm{O}$ mondo, o sperar mio caduco et frale» de Sannazaro por alcanzar el año diecisiete «giungendo al fin del sestodecim'anno»v. 10 (Sonetti et canzoni, Napoli 1530) tiene su antecedente directo en los $R v f$. Aceptando el conocimiento y la noticia de la cifra de Agustín por el poeta napolitano, establecer el alcance y límites en ese canzoniere de su reconocimiento previo en el libro de Petrarca es bastante más aventurado, aunque hayamos de considerarlo.

No sabemos que el poeta napolitano llegase a estar entre los que, de una u otra forma, tuvieron acceso al ordo alternativo propuesto por las postille de los últimos 31 textos del códice de autor. Que en el caso del texto de Sannazaro hay un eco de ese año simbólico que estudiamos en el Canzoniere y en el sonetto CXVIII sí parece evidente. De modo que la composición del libro de Petrarca ofrece elementos de reconocido interés para el poeta napolitano. El caso del sonetto CCXI y la ratio sesquitertia de los Rvf, con su huella en la edición póstuma de 1530, merece una revisión particular que he completado en fecha reciente. Armisén 2011c.

Tras la muerte de Laura, como sabemos, con el comentario sobre la consecuente crisis en terrenos próximos a la desesperación o suicidio (canzone CCLXVIII, vv. 1 ss.) ${ }^{33}$, mediante la trabajada

\footnotetext{
${ }^{33}$ Armisén 2011: 28, n. 22 y p. 31. Tanto el mito de Ifis y Anaxárete como el caso virgiliano de Dido y Eneas, cuyos ecos castellanos he estudiado en trabajos anteriores, son antecedentes clásicos a considerar. Santagata (2005: 20-21) advierte
} 
ampliación a siete stanze de la canzone CCLXX y ahí con la confirmación «Dal laccio d’òr non sia mai chi me scioglia», v. 61, que le retiene aún, el sonetto CCLXXI es el texto que desde sus primeros versos «L'ardente nodo ov'io fui d'ora in hora / contando, anni ventuno interi preso, / Morte disciolse...», señala el veintiún aniversario recordado y destacado después en la breve revisión final del sonetto CCCLXIV. El proceso desde la superbia amenazadora (De musica...VI, 12, 40-41; Secretum II, 70-74 y 80-82 ed. 1992:142 ss. y 152-155 et al.) hacia la necesaria humilitas acompaña la deseada y señalada transformazione, anunciada en el v. 14 del sonetto CCXIII, último verso -ya autógrafo y levemente corregido della stessa mano su rasura- del fol. 42, recto. Zamponi 2004: 30 31.

Es en mi opinión, quizá, la más trabajada aplicación de las cifras que marcan funcionalmente y acompañan la loa de Laura. Tanto el número de folios como el formato de página parecen haber sido elegidos con plena conciencia de sus posibilidades numéricas. Recordemos el caso indicativo y anterior del CLXXXVI, como «sonetto 153» in ordine. Armisén 2013: 200, 229 ss., et al.

Pero no son tampoco las únicas pruebas verificables de composición intencional, medida y significativa. El reconocimiento de la divina proportione en la macrosecuencia iniciada con el sonetto CXVIII y el año 17 establece, como vemos, la relevante función de Morte, actante o personaje decisivo, «fino alla fine del Canzoniere, è l'evento» importante o definitivo (Antonelli 1992: 428), «l'avvenimento centrale dell'autobiografia lirica» (Regn 2007: 574) repetidamente mencionada en el fol. 56 recto, con el final de la canzone CCLXX (153 en esa macrosecuencia de 249 pezzi) y en el sonetto CCLXXI (ó 154). Una interlocutora explícita que, como Fortuna o Amor, quedará sometida a otra causa o poder más alto, declarado en la stanza final de la canzone : «Dio, che sì tosto al mondo ti ritolse, / ne mostrò tanta et sì alta virtute / solo per infiammar nostro desio», vv. 99 ss., tema destacado mediante la trabajada ampliación a siete stanze de la canzone CCLXX.

La numerología evangélica, codificada por Agustín, y la numerología cristianizada vinculada también al pitagorismo platónico proveen la composición formal en que el poeta enamorado (artifex y modulator), con la apetencia de alabanzas, honores y fama (De musica, VI, 13, 41; Secretum, I, 36; II, 130-134; ibid. III, 147; y III, 158 ss.) avanzando en tensiones y debatiéndose entre «fantasiae» y «fantasmae» (De musica VI, 13, 42; Secretum, I, 66-68) desarrolla el conflicto en curso y significará su búsqueda espiritual. Repetidamente, temas y motivos tratados en los De musica libri VI encuentran proyección literaria en las críticas y avisos morales del Augustinus del Secretum. Reconocer los límites de su aplicación de la numerología compilada por Macrobio, que Petrarca conocía, puede ser más difícil. Sin embargo, el caso del famoso 56, principio y fin de ese compendio, reconocido e integrado, frecuente entre los números eternos del poeta, no presenta demasiadas dudas.

sobre la rareza de la tentación del suicidio en la lírica anterior a Petrarca, aunque lo considera (canzoni LXXI, vv. $42-44$ y CCLXVIII, vv. 4-6 y 60-65) un motivo propio de la temática amorosa. Como he señalado, es problema sobre el que Augustinus advierte a Francesco en el Secretum. Años después, la traducción castellana de Garcés es muy explícita, aunque se apoye con la antítesis: «que estoy desesperado / de acá me ver y es esperar tormento», vv. 7-8 de CCLXVII «Che debbio far?, che mi consigli, Amore?». Trato con más detalle el tema y los símbolos de la desesperación de Francesco en las fechas de redacción del Secretum (1347-1354). Vid. Armisén 2011b: pend. de publ.; y su presencia en el Quijote en 2010: 16, nn. 13 y 17, pp. 45 ss., 56, et al. 
Superando el secular y casi regular descuido hacia los De musica..., esa coincidencia sostenida de cifras conocidas (numeri aeterni) ha de tener atención crítica. Ajena al componente autobiográfico más evidente, centrado en los Rerum vulgarium fragmenta por la huella reconocida y dominante de las Confessiones, su incidencia en la construcción literaria del poeta enamorado y culpable de los $R v f$ y del Francesco del diálogo ficticio o en la del propio Augustinus del Secretum debe ser considerada con fundamento. Luque Moreno / López Eisman ed. 2008: 25.

La sucesión de algunos motivos literarios del Canzoniere y el programa o guión de temas del diálogo ficticio encuentran un reiterado, directo antecedente en problemas que antes focaliza y revisa el tratado de Agustín sobre el numerus. Alguno de los hilos conocidos («...le fila benedette», Rvf, sonetto XL), necesarios para la construcción de los textos de Petrarca, forman también parte reconocible de la materia tratada en los De musica y en Confessiones.

\section{Notas finales a componentes cifrados del Canzoniere. Las posiciones de la creación de la dama en el centro del canzoniere de Boscán. Sobre la loa y los vestigia trinitatis. Providentia y divina proportione.}

Juan Boscán, según he podido señalar desde 1982, en el primer cuarteto de su central soneto LXXVII [49] «Puesto m'ha Amor al punto do'stá el medio», como otros lectores atentos de Petrarca, con el conflicto Fortuna/Providencia debió de reconocer la activa presencia literal y formal de esta en la lectura e interpretación redentorista del Canzoniere. Alcanzó alguna noticia del problema teológico en los planteamientos de Agustín e incluso pudo reconocer parcialmente o sospechar con fundamento y evidencias varias el interés del tema en la compleja composición formal del modelo. Armisén 1982: 391-394. El propio texto de 1543, la forma cifrada del canzoniere castellano de sonetos y canciones y, con ella, la influencia evidente del autor de Confessiones avalan esa opinión.

Los cuatro sonetos centrales del Libro II, de 102 componentes, loan en la princeps impresa por Amorós (Barcelona, 1543) la creación divina de la dama, verdadero medio y remedio. Son términos elegidos de intención plural que lo destacan y confirman fuera de toda duda en posición significativa. Un tema focalizado después, en cuanto obra maestra de la Creación (17x3) con el LXXIX [51] «La tierra, el cielo y más los elementos» en términos conocidos: «Dichoso el día, dichosa la hora, / también la tierra donde nacer quiso / esta del mundo general señora», vv. 9-11. Los límites de esa loa merecen valoración. El interés formal e histórico literario de los problemas planteados en 1982 sobre el canzoniere de Boscán, pese a silencios, incomprensión u omisiones varias de los editores modernos y otros estudiosos supuestamente interesados, es ahora fácil de confirmar.

Aunque por distintas razones, dos son los posibles antecedentes a valorar como más relevantes. A todas luces, la composición central que realza el nacimiento de la dama en 1543, motivo anterior conocido del sonetto IV de los Rvf, desarrolla un tema y una forma de composición con precedentes inescusables y reconocibles. Íñigo López de Mendoza, Marqués de Santillana lo trató en posición inicial destacada -como Petrarca en el sonetto IV-, después de 1438, en «Quando yo veo la gentil criatura» soneto I de sus Sonetos fechos al itálico modo, cuidada colección, prologada por el Proemio 
e carta al Condestable don Pedro de Portugal, que Diego Hurtado de Mendoza, descendiente directo del marqués, y quizá también Garcilaso o Boscán probablemente conocían. Armisén 1982: 373-378 y 359 ss.

Destacan en el caso de Boscán las implicaciones universales o cósmicas y divinas, vinculadas a la creación providencial de la dama, potenciadas mediante la concentración de coincidencias y referencias al modelo literario reconocido en esos cuatro textos (centrales, como digo) del primer canzoniere castellano impreso en 1543. Supra texto y antes n. 1.

Recordaré el interés simbólico del número 51 -posible vestigio trinitario según la lectura del sagrado número de los grandes peces de Tiberíades-, múltiplo del 17 de la Gratia [17x3]; como el mismo 153 [50x3 ..+3], comentado y desglosado por Agustín en el In Iohannis...(122, 8), después recordado en las Enarrationes in Psalmos, Ps. CL, 1.

El segundo antecedente a estudiar plantea otros problemas, puesto que nos lleva a la Vita Nuova y a la Divina Commedia. Un número, ese 51, tanto repetido y cifrado por el 17 (17x3) en el Canto XVII del Purgatorio $([1+33]+17 \ldots)$ como así mismo central absoluto en el total unitario de la Commedia de Dante (1/33/33/33). Anterior a su huella en Petrarca, la presencia del 153 evangélico y de Agustín en la obra de Dante merece alguna atención crítica.

El sistema reaparece en 1543, clave central de nuevo en el canzoniere de Boscán de 102 unidades que cierran los 153 versos de la canción «Gran tiempo Amor me tuvo de su mano». No puede ignorarse. Armisén 1982: 405-410; 2004b: 72 n. 10; y 2008a: 64. Lo que no nos lleva a concluir que exista necesariamente una relación numérica determinante, directa y significativa entre esos dos textos, incluso si pensamos que la numerología de Agustín podría, quizá, ofrecer otros datos útiles, a estudiar todavía en la interpretación de la Commedia. Los estudiosos de Dante tienen la palabra.

El caso del nacimiento y función providencial de la dama en los sonetos centrales del Libro II de 1543 -recordemos: medio y remedio...- sí tiene clara filiación petrarquista, aunque establece una variante formal que todavia confunde a algún lector. El valor funcional del 51 en la composición del canzoniere de 102 textos de Boscán es patente y ha de valorarse en relación con el 102 del total y el 153, señalado número de versos de la canción final.

Después, el caso de Nadal y sus Evangelicae Historiae Imagines (Antwerp, 1593) no parece tampoco ejemplo gratuito ni casual. Y el interés del propio Íñigo López de Recalde por lo numérico merece atención. La reaparición del 51 (ó 17x3) como número reconocido de los «Misterios de la vida de Cristo» [apartados 261-312 en los Ejercicios espirituales de Ignacio de Loyola] o la inclusión de la pesca milagrosa ([306 ó 153×2 ...] titulada «Aparición a siete discípulos junto al lago», octavo en los catorce apartados numerados [299-312] subtitulados como «Misterios de la Resurrección» semejan medidos y significativos. Recordemos las opiniones de Pietro Bongo (1585, 1591...) sobre la adecuación particular del número 51 para los misterios. Armisén 2004b: 67 n. 3; y 71 ss., n. 10. 
Como digo, esos mencionados 51 Misterios, pertenecientes a la cuarta semana de los Ejercicios espirituales (Armisén 2004b: 72 n. 10; y 77; Loyola ed. López de Tejada, S. J., Edibesa [1998] 2002: 817), aconsejan tener muy en cuenta otros datos numéricos y sus posibles o presumibles secuelas en textos varios. Tampoco cabe ignorar que en el total de los 370 apartados de esa cuidada edición, el penúltimo apartado, 369 de los Ejercicios, está dedicado a la «Decimoséptima regla: Gracia y libertad». Vid. ed. [1998] 2002: 1021-1027.

En los finales del siglo XX, la actitud en medios religiosos hacia el simbolismo numérico es muy otra, dentro y fuera de la Compañia. Advertiré que la cifra de los 153 peces, sin explicaciones satisfactorias que yo conozca, ha desaparecido de la versión del Evangelio de Juan en alguna Biblia de reconocida filiación jesuítica. La anterior sustitución directa del 153 evangélico por el 150 tampoco resultaba solución nueva satisfactoria. Y reciente es todavía la ampliación de los números del Rosario, en principio el mismo 150 tomado de los Salmos, que pasa a contar con 20 Misterios con la inclusión de los 5 denominados Misterios Luminosos.

El caso de la común aplicación del sistema numérico de Agustín en los Rvf de Petrarca y el Libro II de Boscán parece fundado, difícilmente podría ser casual. Armisén 2004: 76 ss. En esta ocasión, el uso coincidente del mismo sistema cifrado es un hecho significativo por considerar, pero no el único dato a valorar. El tema biográfico, amoroso, confesional, la forma narrativa imitada, la composición del primer canzoniere castellano impreso o numerosos textos y versos clave del barcelonés muestran perceptible relación genérica, intertextual reconocible y funcional (en ocasiones incontestable) con las rime sparse de Petrarca, innovadora recollectio que el amigo de Garcilaso trabajó, muy probablemente en la edición aldina de 1501 controlada por Bembo o en sus secuelas inmediatas (Armisén 2004a: 81), quizá en la de 1514 modificada por el editor Manuzio.

Una forma literaria reconocible, que es consistente en la edición princeps barcelonesa de 1543. La materia temática y la forma de los libros de Petrarca y Boscán están directamente relacionadas; la solución numérica comparte código y cifras antecedentes, es en alguna medida semejante. Ahora podemos verlo, con otra perspectiva, como fuente de información útil en el reconocimiento de la forma de los $R v f$ y su recepción.

El primer canzoniere castellano impreso tiene composición numérica relevante. Documenta y prueba en términos de imitación el reconocimiento tardío o posterior del código de Agustín; y, siquiera parcialmente, con variaciones y otras dimensiones, verifica la reaparición de cifras del modelo reconocido, del caso de composición cifrada por Petrarca que nos ocupa.

Discernir la causa y razón que unifica la cruel, repetida actuación de Muerte en los Rvf era enigma, tragedia o asunto grave a resolver, en términos de composición formal siquiera, por el lector deseado, lector inscrito y propio del texto entretejido por Petrarca. La declaración de los versos 12-14 del sonetto CCLXXI del 21 aniversario plantea de nuevo la sostenida paradoja del CXVIII, v. 5 como problema de lectura. Y ese problema se soluciona directamente reconociendo, valorando la posición de esos mismos versos en la macrosecuencia CXVIII-CCCLXVI de 249 componentes. Como las 
restantes cifras implicadas en esa macroforma, codificada por Agustín de Hipona, tenían antecedentes avalados por Augustinus y por Petrarca, la lectura propuesta semeja hoy inexcusable y documentada.

La divina proportione, construida y delimitada o señalada con el 17 y el 153, cifras redentoristas conocidas, resuelve el tema trágico de la muerte de Laura-vaticinatio post eventum en el Secretum (Armisén 2013: 206 ss.)-, adelantado en los $R v f$ por el timore, enmarcado por sucesivas preghiere, en su chiave formal, paradójica y literalmente. Después, en el trabajado final del libro se funden, confluyen y coinciden o se suman formas finales, secuencias narrativas imbricadas y macrosecuencias varias construidas con la numerología de Agustín.

Reconocer el liminar, demarcativo antecedente del sonetto CXVIII en que, desconfiando de Fortuna y, como digo, confirmando su amor constante, afirma ya la utilidad de su daño parece importante por un creciente número de razones. La evangélica cifra del 153/154 de la Redención estudiada en el In Iohannis... se convierte así en forma constitutiva y es clave formal accesible al cristiano conocedor de la exégesis de la pesca milagrosa, emplazado ahora, atento lector de la secuencia fechada y señalada desde el sonetto CXVIII (forma o redazione Co. 1356-1358) que inició el año décimo séptimo ${ }^{34}$. Las dudas sobre Fortuna enmarcan ahí el problema de Francesco. Después, el sonetto CXXII reitera y subraya el interés cifrado de ese año, subrayan otros motivos que el sonetto CCCXLIX recupera y refuerza finalmente con la misma forma numérica que comento. La macrosecuencia LXI-CCCLXVI de 306 pezzi apoya, diecisiete posiciones antes del final absoluto, el valor del entreoído sonetto «E' mi par d'or in hora udire il messo» con la potenciación simbólica del $17^{2}$.

Realzada por el sistema de aniversarios, en relación con la función última de su amor constante y otros motivos complementarios, las huellas operativas del 17, año que se inicia, y el 153/154 evangélicos señalan también en la canzone CCLXX y el sonetto CCLXXI, como he adelantado, la acción de Providencia en relación con la condición figurada de Laura, introducidas ambas con presumible intención en el sonetto IV. Una presencia, con ecos en alguna ilustración conocida, que pudo interesar al lector propio de los $R v f$ desde la primera página en que se comparó Laura a Juan y Pedro como pescadores divinos con su milagrosa red.

\footnotetext{
${ }^{34}$ Nadal fue responsable hasta su muerte en 1580 del ordo, contenido y comentarios de los 153 grabados numerados (más uno de portada) de las Evangelicae Historiae Imagines, publicadas finalmente por Diego Jiménez en 1593. No dudo que el jesuita mallorquín, que de acuerdo con antecedentes medievales hace coincidir en el grabado 1/CVII la encarnación de Jesús (A, B, C, D, E) con la creación del mundo (F, G, H [Pie credi potest...]) o en el 131/CIV, tras la muerte de Cristo en el 130/CIII, la crucifixión con la interpolación del descenso ad inferos y el juicio final (sicut Rodríguez G. de Ceballos, Imágenes... [Nadal ed. cit. 1975]: 12), y que después cerraba también el libro con cuatro grabados sobre el tránsito, sepultura, resurrección y coronación de María por la Santísima Trinidad, sabía de devociones marianas...y estaba en condiciones de entender y concebir sin problemas tanto la fechación simbólica del primer encuentro con Laura en coincidencia con el viernes santo del sonetto III, como las referencias a la Providencia divina y la rete del IV o la coda mariana de los Rvf, los 137 versos de la canzone CCCLXVI. El caso de Boscán y su Libro II era bastante más sencillo. Conocedor de las propuestas de Agustín sobre la pesca milagrosa, Jerónimo Nadal, matemático y teólogo, podía reconocer con la huella del 17 y el 153 el interés particular de la macrosecuencia de 249 pezzi iniciada el año 17 con el sonetto CXVIII.
} 
La divina proportione es solución formal trabajada y coherente. Parece destinada a convertirse en clave reconocible de la muerte de Laura y de la recuperación espiritual de Francesco para los lectores adecuados. No olvidemos tampoco los Dones del Espíritu Santo y la Gratia, relacionados por Agustín con el 7 y el 17 en el In Iohannis evangelium tractatus y las Enarrationes in Psalmos.

Quizá sea oportuno recordar algo que he señalado en la descripción y primera localización de los textos chiave que nos interesan. Tanto el final de la canzone CCLXX, vv. 88-108, como el sonetto CCLXXI son transcritos en el fol. 56 recto del ms.Vat. lat. 3195 Vid. Petrarca, ed. Modigliani 2004: 341; ed. Savoca 2008a: 438-439 et al. No es necesario insistir en el interés excepcional de esa cifra, el 56 profetizado de la edad de Escipión, número de la plenitud (téleios, en Cicerón plenus), verdadero principio y fin de la numerología de Macrobio -exacto contemporáneo pagano de Agustín- en el excurso aritmológico que Petrarca conocía bien de los Commentariorum in somnium Scipionis libri duo (ed. L. Scarpa 1981: I, 5, 2 ss. y nn. en 379 ss.; y ed. F. Navarro 2006: 148-192, texto y notas).

Sí es obligado recordar que, como apunto en 2011: 21 y reviso con nuevos datos en otro trabajo aún pendiente de publicación, el 56 habia merecido atención declarada como cifra de loa de héroes («...gli altri semidei») en el sonetto CLXXXVI, texto que -si no me equivoco-es ciertamente (también y además), el número 153 in ordine de los sonetti en los Rvf.

Incluso ajeno a estos datos numéricos, Vincenzo Fera en 1987: 223 ss., por razones que considera después en relación con el nombre de Laura, su descriptio y el caso de Scipione, señalaba que «...il punto de inserimento fu scelto con cura». Como advertí, son los sonetti 153 y 154 (CLXXXVI y CLXXXVII) los que, tras el CLXXXV «Questa fenice de l'aurata piuma», comentan la adecuación preferente de los mejores poetas en «...questa pura et candida colomba» [...] «...force scema sue lode parlando» (CLXXXVII, vv. 5-14) Santagata 2004: 814, 417 y 820 ss. No creo verosímil que Petrarca pudiese situarlos en esas posiciones ajeno a la cifra explícita del 56, mencionada con intención como referida a Augusto en el CLXXXVI, v. 7, pero en su momento reconocible a todos los efectos como propia también de Escipión (ni que los transcribiese ignorante del 153/154, codificados por Agustín, aplicados más discretamente mediante su posición en la ordenación particular de los sonetti).

Tuvo que ser un efecto calculado, relacionado con las formas propias de la loa de Laura. Señalaré que el sonetto CLXXXVII (ó 154 de esa forma textual en los $R v f$ ), en que se compara «...questa pura et candida colomba» con Aquiles, tiene en sí también la condición de múltiplo de 17 in ordine (17x11)...; y, aunque de reconocimiento obligado por muchas razones, es o parece ahora un dato de relevancia menor.

Petrarca dejaba constancia en «Se Virgilio et Homero avessin visto» de su interés en las cifras de Agustín y Cicerón o Macrobio, referidas a Escipión y Augusto; e incluso de la adecuación de aunar sus efectos. Su voluntad de integrar la numerología clásica y la evangélica se hace evidente. La conocida, reiterada tentación de comparar Laura y Escipión, revisada también por Fera (descriptio superficialis/descriptio intrinseca), asimilación sostenida como suma o fusión, amplía y subraya los vínculos de numerología y profecía. Se apoya después con la localización coincidente de la providencial muerte de Laura como chiave de la famosa sección áurea en el sonetto CCLXXI y en el 
fol. 56 recto. En mi opinión, como la localización de la data sacra y la ratio sesquitertia en el fol. 42 recto, el sonetto CLXXXVI primero del fol. 38, recto, marcado por el tema de la loa de los héroes, señala de forma explícita y velada (o nos confirma con la referencia del 56 y su posición como sonetto 153) la adecuación funcional como numeri aeterni, el interés del autor en la composición numérica de $\operatorname{los} R v f$.

Si la ratio sesquitertia, coincidente en el CCXI con la recuperada data sacra, parece apoyada por su transcripción en el fol. 42 recto del codice de autor con los 72 folios numerados del Lat. 3195, la divina proportione que marca la influencia de Providentia se presenta en el numerado folio 56 recto del manuscrito. Los fogli in bianco numerados que, poco antes, han completado el último cuaderno de la Parte prima son los fols. 50-52 recto y verso. La composición formal del codice parece destacar y mantener con cifras o razones las posiciones y proporciones significativas del proyecto.

La pretensión de atribuir a fra Luca Pacioli (Borgo Sansepolcro 1445-1517) la descripción cristianizada en 1509 de la aurea ratio en cuanto divina proportione ha de limitarse al campo de la exposición teórica, terreno en el que tampoco faltan precedentes pertinentes, próximos y remotos (Armisén 2011: 14 ss.; Butler 1970: 22 ss.; 47 ss.). Su aplicación funcional, raramente estudiada en los textos según prueban los trabajos clásicos y más conocidos de Foster Hopper, E.R. Curtius o E. Panofsky, parece ser muy anterior como vemos; aunque, acorde con su carácter silencioso y velado, deba ser valorada como materia de interpretación. La atención de Agustín al numerus, a los numeri aeterni de la creación divina (numeros sensibles, de sentido, de réplica o los del recuerdo y los judiciales... etc.), si Petrarca como otros contemporáneos suyos conocía los De musica libri VI (o alguno de sus epítomes) tuvo que interesarle siquiera. Luque Moreno / López Eisman 2008: «Introducción», 56-61; Correa Pabón 2009: 170 ss.

No faltan en la composición de los $R v f$, marcada por textos de interés posicional y biográfico reconocido, motivos varios y elementos numéricos probablemente significativos, descuidados por muchos lectores y estudiosos. Si la relevancia de lo numérico en numerosos detalles menores se impone por su reiteración y la condición sistemática, aunque en no pocos casos parezca también difícil de confirmar de forma absoluta, la atención del poeta de Arezzo a la función simbólica de los números irracionales es ahora verificable. O eso considero por el momento.

No es asunto particular o caso único. Pienso en la loa de Laura cifrada por la tríada del corregido y recuperado sonetto CCXI («Vertute, Honor, Bellezza...»: en la ed. de Savoca, 2008a: 337, separadas por puntos; en la de Modigliani lo mismo, si bien corrige o no respeta las dos últimas mayúsculas). La creo tríada reconocible, integrada en los cinco términos de su descripción y loa de Laura (¿ianua coeli?), a su vez posible vestigium de la péntada pitagórica también significada como número de Afrodita y de la belleza encarnada en cuerpo humano (vv. 9-11). Sin duda son lecturas aventuradas, pero estamos en un texto trabajado y corregido, medido, reconocido como chiave de la ratio sesquitertia del Canzoniere de 362 pezzi (recordemos 4+462) y puerta fechada de entrada al laberinto.

La macrocomposición esbozada en 2004 y 2008 puede confirmarse con nuevos detalles y datos significativos, sostenida con la numerología de Agustín y, según vemos, vinculada a la huella 
emergente de Providencia en los Rerum vulgarium fragmenta. Reconocer su ajuste, coincidente con el conocido 56 del vaticinio sobre la muerte de Escipión comentado por Macrobio, prueba (en mi opinión) la verificable intencionalidad compositiva; pero su sentido particular nos retiene, como digo, una vez más, en los espacios de la lectura. Pensemos que la relación del 7 y el 8, comentada por Macrobio, mereció así mismo la atención de Agustín como símbolos de la Gloria. Foster Hopper [1938] 1978: 77, 83-85, et al.

La recuperación de los números eternos de Agustín que Petrarca asume no quedaba limitada por los Evangelios. Y aunque no sean los datos más creibles ni determinantes que podemos aducir, lo apunta o sugería, quizá, el codice Vat. lat. 3195 desde los $56 \mathrm{vv}$. del medido e intencional formato de su primera página (en esa ocasión significativo $1+2+3+4$, relacionado con la creación providencial de Laura), tantas veces repetido después. La integración de los 4 sonetti prologales en el total de 366 fragmenta parece apoyada por el diseño formal y la cuidada paginación del codice autorizado.

La obra de Pacioli recuerda en 1509 la confluencia de la tradición pitagórica con la arquitectura descrita en el siglo I a. de C. por Vitruvio (Armisén 2008a: 56 n. 3; A.M. González introducción y texto de L. Pacioli ed. 1991: 22-26; después cap. II, 33-37; cap. LIV, 99-101 et al) ${ }^{35}$. Valorando la relación de la numerología cristiana con las propiedades y adecuación de los números irracionales, leemos la proyección de Providencia y de la Redención en la composición numérica redentorista apoyada por el 56 de Escipión y Augusto ${ }^{36}$ (...Cicerón, Ausonio y Macrobio). Una lectura señalada y construida formalmente con el 17 de la Gratia y el 153 redentorista en los Rvf; relación cifrada por la sección áurea en cuanto divina proportione antes de 1374 en el codice Vat. lat. 3195. Ofrece nueva luz en un detalle o tema de teología formal poco documentado.

Son composiciones y medidas con antecedentes varios. La forma simbólica de unitaria totalidad en 72 componentes del códice de autor la encontramos entre los temas o cifras relevantes -Elementos de Euclides y Panteón de Roma incluidos...- que interesan muchos años después a Pacioli. Armisén 2011: 15 ss. y nn. 8, 9 y 10. El sistema numérico cristiano desarrollado por Agustín sobre el 17 y el 153 evangélico, cifrado así mismo con las 137 páginas de los $R v f$, probablemente, completa su ajuste

\footnotetext{
${ }^{35}$ No faltan puntos de coincidencia con el hiponense, aunque Pacioli, autor también de la Summa de Arithmetica Geometria Proportione et Proportionalità (Venezia, 1494), al referirse a la numerología cristianizada de Agustín se limite en De Divina proportione (1509) a mencionar sus observaciones numéricas generales en De civitate Dei. Vid. Pacioli ed. 1991: «Del título que conviene al presente tratado o convenio» cap. V, 41-42; «Cómo, por reverencia de nuestra salvación, terminan dichos efectos», cap. XXIII, 59-60 et al.

${ }^{36}$ Según hemos visto, Petrarca, conocedor del texto de Macrobio, hace en destacadas ocasiones uso simbólico calculado del 56 de Escipión. Verificarlo en la numeración original de los folios del codice nos lo confirma. Su uso literario interesa a Petrarca. Ejemplifica la tradicional relación de cifra numérica y profecía recogida y estudiada por M. S. Røstvig (1970), mencionada por G. Gorni (1990). Casi siempre implícito y con intencionalidad cuestionable en su aplicación simbólica particular, habilita repetidamente -como en el aventurado ejemplo de XXXVII, v. 56- las consiguientes lecturas. No faltan casos en los que la cifra o su intención como pauta formal parece incierta o es dudosa. Pienso ahora en el número de textos que separan el inicio de la macrosecuencia de 306 pezzi de il riscatto (LXI-CCCLXVI) de la de 249 unidades (CXVIIICCCLXVI) que ahora comento. Si el cómputo lo comenzamos con el sonetto LXI encontramos 57 textos. Serían exactamente 56 si computamos solo los que marcan los dos textos de aniversario, desde el sonetto LXII Padre del ciel... (del undécimo aniversario) hasta el sonetto CXVIII en que, cumplido el año 16, se inicia el 17. El ordo de los textos y el formato del codice ofrecen otras huellas de la cifra: 4+56+306 (Armisén 2008a: 54-55 y 57); y como apunté (supra y 2008a: 59-61), 56 es desde el fol 1, recto el número de versos en la repetida, modular, canónica página de cuatro sonetti, etc. También Brugnolo 2004: 108 ss., 122-126; W. Storey 2004: 152-155; y Armisén 2011 b.
} 
en un total de folios numerados por el propio autor, según parece, cifrado por el 72 y relacionado quizá, como en la sestina doppia, con el 6 y el 12.

Tal vez alcanza proyección previa, preámbulo o eco armónico en la cifra de esos 12 meses de 1342-1343 (palcoscenico de los Rvf..., sic. McMenamin 2001: 6-8) y en el total de los días del año en los 366 fragmenta. Son, en otros textos y ocasiones varias, los 12 apóstoles (Lucas, IX, 1) y 72 discípulos (Lucas, X, 1-2) que, según los Evangelios proyectan el programa cristiano en el Universo. Números que cuentan también, como digo, con el confuso y preciso antecedente de la traducción conocida de Euclides vigente en esos años, todavía no depurada de pasajes espúreos; y después con las tardías (y erróneas) propuestas de Pacioli en 1509 sobre el Panteón de Roma, Armisén 2011: 14 ss y nn. 6-10.

Algunos de los hechos formales que considero resultan de confirmación harto difícil y son hoy (o parecen), como la misma información numerológica más general, si ignoramos sus precisos orígenes y condición sistemática en Agustín, solo datos de acarreo. Otros son de interés general o no prueban nada ahora, pero sí documentan que esos mismos números, en fechas que nos interesan, aparecían vinculados, acertada o incluso erróneamente, con obras importante. Han sido considerados significativos en el pasado y fueron relacionados con formas o textos destacados. Y alguno incluso tiene uso simbólico probado en los Evangelios o en textos clásicos conocidos.

Consecuentemente, de acuerdo con las observaciones de Dotti (2001: 13), no intentaré verificar todas las cifras particulares, ni delinear cada una de las lecturas que, tal vez, para otros lectores, en algún momento, daban forma a ciertos detalles en las medidas proporciones del drama. Recordemos también, tras la valoración de aportaciones de Pötters, las repetidas y ocasionales propuestas mencionadas en trabajos de Gorni (1989), Berra (1991), Dotti (2001), McMenamin (2001) et al., o las recogidas en las necesarias e importantes, documentadas, monumentales ediciones de Santagata y Bettarini. La activa presencia del sistema numérico de Agustin obliga a reconocer con provecho y revisar su integración funcional en los $R v f$.

Contrastar la forma narrativa del continuum de las rime sparse con la estructura compositiva posicional de pórticos o retablos de iglesias y frescos murales centrados regularmente por la vita Christi, permite también reconocer la presencia reiterada o la adecuación de algunas cifras implícitas y de relevantes motivos. Puede parecer aventurado, pero tiene el apoyo que las formas de composición numérica y modular o el modelo arquitectónico del «aedificium petrarchesco» permiten. Es información y son lecturas de formas narrativas espaciales y secuenciales que pronto nos llevarían demasiado lejos. La huella del mismo sistema numérico y sus correlatos posicionales en los grabados de las Evangelicae Historiae Imagines y en la composición barroca de la Piazza di San Pietro ayuda a verificar su consistencia en la tradición icónica cristiana, las dimensiones significativas y temporales del tema, su cifrada pervivencia, la reaparición en textos documentados y espacios sagrados de interés histórico.

Recordar lo que se ha dicho ocasionalmente sobre el 12 y sus correlatos numéricos, cronológicos o espaciales en el Canzoniere ejemplifica, de nuevo, la coexistencia de diversos códigos en la plural 
composición de los Rerum vulgarium fragmenta y en el Vaticano latino 3159. Al menos, en alguna ocasión, nos ayuda en su lectura numérica general. No es caso único, ni tampoco el más evidente.

El componente dominante de la composición procede de las propuestas numéricas de Agustín, aunque sin exclusión de cifras, razones y números clásicos o sus antecedentes pitagóricos a valorar como intencionales, próximos al pensamiento del poeta humanista. Con el apoyo verificado de la conocida cifra clave del vaticinio sobre Escipión, vir bonus pagano de interés constante para Petrarca, el valor confirmado del dominante sistema numérico redentorista fundado con el 17 y el 153 construye el sistema operativo modular e ideológico en la biografía espiritual de 137 páginas.

Superando los límites impuestos por el tema de la consolatio pagana ante Morte y la presentida, trágica pérdida del ser querido fechada en el sonetto CCCXXXVI, Petrarca se transforma con su poesía espiritual, según adelantó in vita...(recordemos lo escrito en 2008: in advance y post eventum) el CCXIII, v. 14; y formaliza como enigma del codice autorizado, con los últimos textos transcritos pocos meses antes de su muerte, una solución providencialista y cristiana mediante la redentorista composición numérica agustiniana. Saber que esa forma modular, significada por sus proportiones y rationes, pudo tener antecedentes en la tradición vitruviana y en la composición de los poetas clásicos que Petrarca había trabajado más desde su juventud no parece inútil. Confirmarlo a estas alturas y con rigor absoluto ha de ser mucho más difícil. Dejémoslo así.

Sin embargo, como hemos visto, las posiciones señaladas, secuencias narrativas cifradas y números repetidos del estudiado codice resultan válidos como datos operativos a evaluar: son o parecen componente propio fehaciente, tejen y sostienen una construcción trabajada con numeri aeterni originales e incluso sagrados, una opción formal significativa, intencional y calculada.

Las dudas no se acaban, aunque la lectura se afirma confesional espacio textual de tentativa búsqueda. Si, como he señalado en 2008, el 72 es el autorizado número de folios, total solidario de la ratio sesquitertia localizada desde esa fecha en texto literario y codice con la data sacra del sonetto CCXI -y con la transcripción del CCXIII (cuarto sonneto del fol. 42, recto) en el grupo central desplazado-, la realidad formal de ambos (texto y codice) se presenta actualizada con numerología cristiana evangélica, fundacional. Y esa ratio sesquitertia confirmada se refuerza y potencia en términos teológicos, marcados de nuevo por la numerología de Agustín, con el reconocimiento operativo de la ratio aurea como divina proportione y la cifrada huella de Providentia o de la Gratia.

\section{Referencias bibliográficas}

AA. VV. (1987): Enciclopedia Virgiliana, 5 vols. Roma, Istituto della Enciclopedia Italiana.

(1993): The New Princeton Encyclopedia of Poetry and Poetics, edited by Alex Preminger and T.V.F. Brogan, Princeton, Princeton University Press.

(2004): Rerum vulgarium fragmenta. Codice Vat. lat. 3195. Commentario all'edizione in facsimile, a cura di Gino Belloni, Furio Brugnolo, H. Wayne Storey e Stefano Zamponi, Roma/Padova, Editrice Antenore. 
(2007): Lectura Petrarcae Turicensis. Il Canzoniere. Lectura micro e macrotestuale a cura di Michelangelo Picone, Ravenna, Longo Editore.

Agustín DE HiPONA ([1946] ed. 1968): Confessiones, Obras de San Agustín, Madrid, BAC, vol. II, texto bilingüe y edición crítica de Ángel Custodio Vega.

— ([1947] ed. 1963): De libero arbitrio, ed bilingüe, versión, introducción y notas del P. Evaristo Seijas en Obras de San Agustín, vol III, Madrid, BAC.

- (ed. 1958): Tractatus in Iohannis Evangelium, Obras de San Agustín, Madrid, BAC, vol. XIV, ed. bilingüe, trad. Vicente Rabanal.

_ (ed. 1954-1957): Enarrationes in Psalmos, Obras de San Agustín, Madrid, BAC, vols. XIXXXII, ed. bilingüe preparada por Balbino Martín Pérez.

— (ed. 1988): De musica libri VI, Obras de San Agustín, Madrid, B AC, vol. XXXIX, pp. 65-361; ed. bilingüe de Alfonso Ortega.

— (ed. 2008): Sobre la música. Seis libros, Madrid, Biblioteca clásica Gredos.Edición, traducción y notas de Jesús Luque Moreno y Antonio López Eisman.

- (ed. 2000): De civitate Dei, Obras completas de San Agustín, Madrid, BAC, vols. XVI y XVII, ed. bilingüe. Trad. de Santos Santamarta del Río y Miguel Fuertes Lanero; introd. y notas de Victorino Capanaga.

ANTONELLI, R. (1992): «Rerum vulgarium fragmenta di Francesco Petrarca», Letteratura Italiana, Le Opere, Dir. A. Asor Rosa, vol. primo, pp. 379-471. Torino, G. Einaudi editore.

ARENDT, H. ([1929] 2001): El concepto de amor en san Agustín. Madrid, Ediciones Encuentro.

ARISTÓTELES (ed. 1970): Metafísica, ed. trilingüe de Valentín García Yebra, vol. I, Madrid, Ed. Gredos.

ARMisÉn, A. (1982): Estudios sobre la lengua poética de Boscán, La edición de1543, Zaragoza, Libros Pórtico/Universidad de Zaragoza.

- (1986): «Admiración y maravillas en El Criticón (más unas notas cervantinas)», en AA. VV., Gracián y suépoca. Actas de la I Reunión de Filólogos Aragoneses [1985], Zaragoza, Institución Fernando el Católico, pp. 201-242. Existe edición de estas Actas en la red como pdf. Todos los artículos de A. Armisén citados en esta bibliografía pueden ser consultados también en «academia.edu».

- (1998): «Sobre el hombre y el nombre. Notas de lectura a "Para que yo me llame Ángel González"», Grama y Cal, 2, pp. 129-145.

- (1999): Jugar y leer. El Verbo hecho tango de Jaime Gil de Biedma, Zaragoza, Prensas Universitarias de Zaragoza.

- (2004a): «Composición numérica e imitación. El 153 de la pesca milagrosa, la exégesis de Agustín y su huella en Petrarca y Boscán», Cuadernos de Filología Italiana, vol. 11, pp. 75-98. - (2004b): «Sobre el 153 y la Piazza di San Pietro di Roma. Bernini y la numerología jesuítica. El caso Gracián», Boletín Museo e Instituto Camón Aznar, XCIV, 2004, pp. 65-101. Vid. como $p d f$ en «academia.edu». 
(2005): «Composición numérica en Petrarca, Boscán y Shakespeare. Nota sobre el caso de Sir Thomas Wyatt y Garcilaso de la Vega», en El 'Canzoniere' de Petrarca en Europa: ediciones, comentarios, traducciones y proyección, Actas del Seminario Internacional Complutense (10-12 de noviembre de 2004) edición de María Hernández Esteban, Cuadernos de Filología Italiana. - (2007): «Clásicos y modernos. Notas barcelonesas sobre Hölderlin, Heidegger y Lukács en la poesía de Jaime Gil de Biedma», en Pensamiento literario español del siglo XX, 1, Anexos de Tropelías, Zaragoza, pp. 7-41.

(2008a): «Sobre la composición del Canzoniere (codice Vat. lat. 3195): sistema de peticiones, macrosecuencias y sesquitertia ratio», Cuadernos de Filología Italiana, 15, pp. 47-72.

- (2008b): «Los sueños dialogados. Los límites de la vivencia petrarquista de Antonio Machado» [2006], Pensamiento literario español del siglo XX, 2, pp. 23-49.

(2010): «Garcilaso y el verso travestido de Altisidora. Anaxárete, Dido, Avellaneda y la escritura meliorativa del Quijote de 1615», en AA. VV., Cervantes en el espejo del tiempo, coordinado por $\mathrm{M}^{\mathrm{a}}$ Carmen Marín Pina, Zaragoza, Servicio de publicaciones de la Universidad de Alcalá y Prensas Universitarias de Zaragoza, pp. 15-60.

(2011): «Composición secuencial y lectura numérica (texto literario y códice de autor) en los Rerum vulgarium fragmenta: el sistema de aniversarios y sus incongruencias», Perusia, VII, pp. $9-40$.

—_ ([2011b]...): «Lecturas e hipótesis sobre cifras de Agustín y Macrobio en el programa simbólico de Petrarca. La desesperación, la higuera de Confessiones y el árbol cruz». Texto pendiente de publicación.

([2011c] 2014...): «El Canzoniere de Petrarca y el caso Sannazaro: composición numérica petrarquista y nostalgia poética. El año 17 y la ratio sesquitertia de la data sacra (Rvf) en los Sonetti et canzoni de 1530». Texto acabado, actualmente pendiente de publicación en Critica Letteraria.

- (2012): «Símbolos unitarios en el tejido del Canzoniere: las redes de los sonetos IV, LXII y CLXXXI. La petición de hilos del XL. Del soneto XXVI a la sextina doble», Cuadernos de Filología Italiana, XIX.

- (2013): «Posiciones, causas y razones en los Rvf: 1.- Voluntad de acabar y Spes. La vaticinatio post eventum de Augustinus. Transcripciones y ordo plural del codice Vat. lat. 3195», Tropelías, 19, pp. 196-248.

ARQuímEDES (ed. 2005): Medida del círculo, pp. 235-250 en Arquímedes, Tratados / Eutocio, Comentarios (selección), con introducciones, traducción y notas de Paloma Ortiz García, Gredos, Madrid.

BALDASSARRI, G. (2004): «Il tema della fortuna», Italianistica, anno XXXIII, num. 2, pp. 29-34.

BARANSKI, Z. G. (2007): «'Piangendo e cantando' con Orfeo (e con Dante): strutture emotive e strutture poetiche in Rvf 281-290», en AA. VV. (2007), pp. 617-640. 
280 Tropelías. Revista de Teoría de la Literatura y Literatura Comparada, 23 (2015)

Antonio Armisén

BARBEL, J. A. (1982): «Il sonetto CXIII e gli altri sonetti a Sennuccio», Lectura Petrarce, II, pp. 21 39.

BAUER, D. (2012): «Beyond the frame(s). Narrative and Representation in Jerome Nadal's Evangelicae Historiae Imagines», en Crosscurrents in Illustrated Religious Texts in the North of Europe. 1500-1800. (12-13 January, 2012), en http://www.academia.edu/901608/_CONFERENCE_ PAPER_Beyond the Frame_s_. Narrative_and_Representation_in_Jerome_Nadals_Evangelic ae_Historiae_Imagines_Antwerp_1593 (última consulta, 6-9-2014).

Belloni, G. (2004): «Nota sulla storia del Vat. lat. 3195», en AA. VV. (2004), pp. 73-104.

Belloni, G. - PUlsoni, C. (2006): «Bembo e l'autografo di Petrarca. Ancora sulla storia dell'originale del Canzoniere», Studi Petrarcheschi, 19, pp. 149-184.

BEHAR, R. (2013): «"Empeçó a recebir aquella vista / de aquel sol que aserenaba el mundo...”: el Leandro de Boscán y la filografía del Renacimiento», Studia Aurea, 7, pp. 267-302.

BENINI, S. (2000): «L'inattingibile realtà dell'illusione: presenza ed assenza di Laura nel Canzoniere» en AA. VV., Petrarca e i suoi lettori, a cura di V. Caratozzolo e G. Güntert, Università di Zurigo, Ravenna, Longo editore, pp. 91-107.

Bertolani, M. C. (2005): Petrarca e la visione dell'eterno, Il Mulino, Bologna.

BetTARINI, R. ([1987] 1998): «Voltando pagina... (Petrarca, Rvf CCLXX-CCLXXI)», Rivista di Letteratura Italiana, 1987, pp. 225-245. Integrado después como «Il planctus per la "sua" donna», en Bettarini (1998), pp. 61-83.

([1987b] 1998): «“Che debb'io far?” (RVF CCLXVIII)», Lectura Petrarce, VII, pp. 187-199; después cap. II, 1 «I pianti per le donne amate», en Bettarini (1998), pp. 45-59.

- (1998): Lacrime e inchiostro nel Canzoniere di Petrarca, Bologna, Clueb.

Billanovich, G. (1966): «Petrarca e il Ventoso», cap. X en Petrarca e il primo umanesimo, Padova, Antenore, 1996, pp. 168-186, edición por la que cito.

Bologna, C. (1998): Il ritorno di Beatrice. Simmetria dantesche fra Vita nuova, «Petrose»e Commedia, Roma, Salerno Editrice.

Borsi, F. (1980): Bernini Architetto, Milano, Electa Editrice, portada y pp. 64-96.

BRUGNOLO, F. (2004): «Libro d'autore e forma-canzoniere: implicazioni grafico-visive nell' originale dei 'Rerum vulgarium fragmenta'», en AA. VV. (2004), pp. 105-129.

BuTLER, C. (1970): Number Symbolism, London, Routledge and Kegan Paul.

CAligiure, T. (2013): «Inextricabile ergastulum. Il tema del labirinto nelle "Epystole" di Petrarca», Petrarchesca, n. 1, pp. 103-117.

Capovilla, G. (2007): «Il canto di Laura», en Francesco Petrarca: da Padova all'Europa, Atti del convegno internazionale di studi Padova, 17-18 giugno 2004 a cura di Gino Belloni, Giuseppe Frasso, Manlio Pastore Stocchi, Giuseppe Velli. Roma/Padova, Editrice Antenore, pp. 115-128.

CAPPEllo, G. (1998): La dimensione macrotestuale. Dante, Boccaccio, Petrarca. Ravenna, Longo Editore. 
CARRAI, S. (2007): «I primi testi autografi del Vaticano 3195 (RVF 190-200)», en AA. VV. (2007), pp. $432-447$.

Chessa, S. (2005): Il profumo del sacro nel Canzoniere di Petrarca, Firenze, Società Editrice Fiorentina.

Correa PABÓN, G. L. (2009): Numerus-proportio en el De música de san Agustín, (Libros I y VI). La tradición pitagórica y platónica. Tesis doctoral, Universidad de Salamanca, mayo de 2009, pdf.

Curcio, G. (2003): «Del Trasporto dell'Obelisco Vaticano, e sua Erezione», en Carlo Fontana, Il Tempio Vaticano, 1694, edizione a cura di Giovanna Curcio, Milano, Electa, pp. CLXXCLXXXVII.

DEKONINCK, R. (2005): «L'invention de l'Image de la Compagnie de Jésus entre Rome et Anvers», Italia Belgica, N. Dacos \& C. Dulière eds., Turnhout, Brepols, pp. 163-187.

DotTi, U. (2001): Petrarca civile. Alle origini dell'intellettuale moderno, Roma, Donzelli.

Duckworh, G. ([1962] 1980): Structural Patterns and Proportions in Vergil's Aeneid, Ann Arbor, University of Michigan Press / London. Ed. Facsimile University Microfilms International, Ann Arbor / London.

EUCLIDES ([ed. 1991-1996]): Elementos, Gredos, 3 vols. Introd. Luis Vega; trad. y notas de María Luisa Puertas Castaños.

FEnzI, E. ([1998] 2003): «Sull’edizione del Canzoniere di Petrarca commentata da Marco Santagata», Saggi petrarcheschi, Fiesole, Cadmo, pags. 139-198.

- (2007): «I percorsi del lutto (Rvf271-280)», en AA. VV. (2007), pp. 595-615.

- (2008): Petrarca, Profili di Storia Letteraria a cura de Andrea Battistini, Bologna, Il Mulino.

FERA, V. ([1987] 1988): «I sonetti CLXXXVI e CLXXXVII», Lectura Petrarce, VII, presso Leo S. Olschki, Firenze.

FOSTER HoPper, V. ([1938] 1978): Medieval Number Symbolism, Columbia University Press. Uso la ed. facsímil de Norwood Editions, 1978.

Fowler, A. [A. FO.] (1993): «Numerology», en AA. VV., The New Encyclopedia of Poetry and Poetics, edited by A. Preminger and T. V. F. Brogan, Pinceton, Princeton University Press, pp. 845-846.

FrAZER, J. G. ([1890] 1981): La rama dorada, Madrid, Fondo de Cultura Económica.

FRYW, N. ([1982] 1988): El gran código, Barcelona, Gedisa.

Galbiati, G. S. (2004): «Sulla canzone I' vo pensando (RVF 264): 1'ascendente agostiniano ed altre suggestioni culturali», en Petrarca volgare e la sua fortuna sino al Cinquecento, a cura di B. Porcelli, Italianistica, 2/2004, pp. 109-121.

GANTERT, R. (2000): «Canzoniere CXXIX: "Di pensier in pensier, di monte in monte"», en AA. VV., Petrarca e I suoi lettori, V. Caratozzolo \& G. Güntert eds., Ravenna, Longo Editore, pp. 55-77. Giannarrelli, E. (2004): «Quale e quanto Agostino al tempi del Petrarca», en AA. VV., Petrarca e Agostino [2000], a cura di Roberto Cardini e Donatella Coppini, Roma, Bulzoni, pp. 1-17.

GoRNI, G. (1990): Lettera Nome Numero. L'ordine delle cose in Dante, Bologna, Il Mulino. 
282 Tropelías. Revista de Teoría de la Literatura y Literatura Comparada, 23 (2015)

Antonio Armisén

Lacoste, J.-Y. (2007): Dictionnaire critique de théologie, sous la direction de Jean-Yves Lacoste, Paris, PUF.

Livio, M. (2006): La proporción áurea. La historia de phi, el número más enigmático del mundo, Barcelona, Ariel.

Loyola, I. DE ([...1539] 1998): Los Ejercicios Espirituales. Comentarios y textos afines. Edición, Prólogo, Introducción general y anotaciones, etc. de Darío López Tejada, S.J., Madrid, Edibesa. Ludolfo de Sajonia [ed. 1530] ( $1^{\text {a }}$ ed. cast. 1502-1504): Vita Christi Cartuxano, trad. de fray Ambrosio Montesino, Alcalá. Cito por la edición de Sevilla, 1530, Cromberger.

Macrobio, A. T. (ed. 1981): Comentariorum in somnium Scipionis Libri Duo, introduzione, testo, traduzione e note a cura di Luigi Scarpa, Padova, Liviana Editrice.

- (2001) Commentaire au Songe de Scipion, Livre I, texte établi, traduit et commenté par Mireille Armisen-Marchetti, Paris, Les Belles Lettres.

- (2006): Comentario al Sueño de Escipión de Cicerón, introducción, traducción y notas de Fernando Navarro Antolín, Madrid, Gredos.

MCLaughlin, M. (2007): «Struttura e sonoritas in Petrarca (Rvf 151-60)», en AA. VV. (2007), pp. 361-382.

McMenamin, J. F. (2001): «Un anno nel Canzoniere di Petrarca», Studi Italiani, XIII, 1, pp.5-21.

MinICINI, P. (1963): «Les proportions mathématiques dans l'Eneide», Latomus, XXII, pp. 263-272.

NADAL, J. (1593) Evangelicae Historiae Imagines, Antwerp, Cristobal Plantin. La edición de 1593 es accesible en https://archive.org/details/evangelicaehisto00pass (última consulta, 6-9-2014).

- (1975): Imágenes de la Historia Evangélica, edición facsimil con estudio introductorio de Alfonso Rodríguez G. de Ceballos Barcelona, Ediciones el Albir, 1975. La introducción se publicó antes en Traza y Baza, 5, 1974, pp. 77-95.

- (2008): Biblia Natalis. La Biblia de Jerónimo Nadal, S. J., Deusto Publicaciones. Mensajero. Con introducción de Isidoro Pinedo Iparraguirre; edición bilingüe de los pretextos iniciales y las anotaciones latinas originales con traducción castellana por Santiago Segura Munguía; reproducción fotográfica de la princeps de 1593.

NolHaC, P. DE ([1892] 1965): Pétrarque et l'humanisme, 2 vols., Paris, Librairie Honoré Champion.

PACCA, V. ([1998] 2004): Petrarca, Roma, Editori Laterza.

PaCioli, L. (1509 [1991]): La Divina proporción, con «Introducción» de Antonio M. González, traducción de Juan Calatrava, Madrid, Ediciones Akal.

PANOFSKY, E. ([1921, 1955] ed. 2006): «La historia de la teoría de las proporciones humanas como reflejo de la historia de los estilos», en El significado en las artes visuales, Madrid, Alianza Editorial, pp. 77-130.

Pastore Stocchi, M. (1994): «I sonetti del guanto (CXCIX, CC, CCI)», Lectura Petrarce, XIV, pp. 251-262.

Petrarca, F. (1525 y 1538): Le Opere Volgari del Petrarcha con le espositione di Alessandro Vellutello da Lucca, Venezia. 
([1899] ed. 1984): Le Rime, a cura de Giosuè Carducci e Severino Ferrari reeditada con prólogo de Gianfranco Contini, Firenze, Sansóni.

([1904] ed. 2004): L'edizione diplomática di Ettore Modigliani. Francisci Petrarche Laureati Poete Rerum vulgarium Fragmenta (Rome), reimpreso en AA. VV. (2004), pp. 173-376.

([1996] ed. 2004): Canzoniere, a cura di Ugo Dotti, 2 vols., Roma, Donzelli Editore.

([1996] ed. 2004): Canzoniere, edizione comentata a cura di Marco Santagata, Milano, Mondadori.

(1996): Trionfi, Rime estravaganti, Codice degli abbozzi a cura di Vinicio Pacca e Laura Paolino, Introduzione di Marco Santagata, Milano, Arnoldo Mondadori Editore.

— (ed. 2005): Canzoniere. Rerum vulgarium fragmenta a cura di Rosanna Bettarini, Torino, Giulio Einaudi Editore.

(ed. 2008a) Rerum vulgarium fragmenta, edizione critica di GiuseppeSavoca, Leo S. Olschki Editore, Firenze.

(ed. 1992): Secretum / Il mio segreto, a cura di Enrico Fenzi, edizione commentata bilingue, Milano, Mursia.

(ed. 2011): Mi secreto / Epístolas. Edición bilingüe de Rossend Arqués Corominas, Madrid, Cátedra.

(ed. 2006): Le postille del Virgilio ambrosiano, a cura di M. Baglio, A. Nebuloni Testa e M. Petoletti. Presentazione di G. Velli, II vols. Roma/Padova, Editrice Antenore.

Petrini, M. (1993): La risurrezione della carne. Saggi sul Canzoniere, Milano, Mursia.

Picone, M. (2007a): «Petrarca fra patimento amoroso e pentimento religioso (Rvf 61-69)», en AA. VV. (2007), pp. 161-182.

- (2007b): «Amor e Gloria nella composizione 110-119 di Rvf», en AA. VV. (2007), pp. 279294.

PÖTTERs, W. (1984): «Chi era Laura? - Strutture linguistiche e matematiche nelle Rime di Francesco Petrarca», Atti della Academia delle Scienze di Torino, 118, pp. 165-180.

- (1987): Chi era Laura? Strutture linguistiche e matematiche nel Canzoniere di Francesco Petrarca, Bologna, Il Mulino.

- (1998): Nascita del sonetto. Metrica e matematica al tempo diFederico II, Ravenna, Longo Editore.

(2007): «Fragmenta o liber? Note sulla struttura del Canzoniere di Petrarca», Letteratura Italiana Antica, Anno VIII. Studi in Memoria di Mirella Moxedano Lanza, tomo II, pp. 279-298. Praloran, M. (2007): «Alcune osservazioni preliminari sul senso della forma nel Canzoniere», en AA. VV. (2007), pp. 73-114.

REGN, G. (2007): «La decade della bipartizione (Rvf 261-70)», en AA. VV. (2007), pp. 569-593. Rico, F. (1974): Vida u obra de Petrarca. Lectura del Secretum. Padova, Editrice Antenore. 
RøSTVIG, M.-S. (1970): «Structure as prophecy: the influence of biblical exegesis upon theories of literary structure», en AA. VV., Silent Poetry, edited by A. Fowler, London, Routledge and Kegan Paul, pp. 32-72.

SAnNAZARO, J. (1961): Opere volgari, a cura di Alfredo Mauro, Bari, Gius. Laterza.

Santagata, M. (1975): «Conessioni intertestuali nel Canzoniere del Petrarca», Strumenti Critici, 26, pp. 80-122.

- ([1979] 1989): Dal sonetto al Canzoniere. Richerche sulla preistoria e la costituzione di un genere. Padova, Liviana Editrice.

- (1992): I frammenti dell'anima. Storia e racconto nel Canzoniere di Petrarca, Bologna, Il Mulino.

- (2005): «Acedía, aegritudo, depresión: modernidad de un poeta medieval», en AA. VV., El Canzoniere de Petrarca en Europa: ediciones, comentarios..., Actas del Seminario Internacional Complutense, Madrid, CuFI, pp. 17-25.

Sapegno, M. S. (1999): Petrarca e lo stile della Poesia, Bagatto Libri, Roma.

SAvocA, G. (2008b): Il Canzoniere di Petrarca tra codicologia ed ecdotica, Firenze, Leo S. Olschki.

Soldani, A. (2006): «Un'ipotesi sull'ordinamento finale del Canzoniere (Rvf, 336-66)», Studi Petrarcheschi, 19, pp. 209-247.

Storey, H. W. (2004): «All'interno della poetica grafico-visiva di Petrarca», en AA. VV. (2004), pp. 131-171.

Stroppa, S. (2014): Petrarca e la morte tra Familiari e Canzoniere, Roma, Aracne.

TONELli, N. (1999): Varietà sintattica e costante retoriche nei sonetti dei Rerum vulgarium fragmenta, Firenze, Leo S. Olschki Editore.

- (2007): «Vat. lat. 3195: un libro concluso? Lettura di Rvf360-66», en AA. VV. (2007), pp. 799822.

Williams, P. (1996): «Canzoniere 366: Petrarch's critique of stoicism», Italian Studies, 51, pp. 27 43.

ZAMPONI, S. (2004): «Il libro del Canzoniere: modelli, strutture, funzioni», en AA. VV. (2004), pp. 13-72. 